\title{
Review and Evaluation of Metallic TRU Nuclear Waste Consolidation Methods
}

\author{
D. R. Montgomery \\ J. F. Nesbitt
}

August 1983

Prepared for the U.S. Department of Energy under Contract DE-AC06-76RLO 1830

Pacific Northwest Laboratory Operated for the U.S. Department of Energy by Battelle Memorial Institute 


\title{
DISCLAIMER
}

This report was prepared as an account of work sponsored by an agency of the United States Government. Neither the United States Government nor any agency thereof, nor any of their employees, makes any warranty, express or implied, or assumes any legal liability or responsibility for the accuracy, completeness, or usefulness of any information, apparatus, product, or process disclosed, or represents that its use would not infringe privately owned rights. Reference herein to any specific commercial product, process, or service by trade name, trademark, manufacturer, or otherwise, does not necessarily constitute or imply its endorsement, recommendation, or favoring by the United States Government or any agency thereof. The views and opinions of authors expressed herein do not necessarily state or reflect those of the United States Government or any agency thereof.

\author{
PACIFIC NORTHWEST LABORATORY \\ operated by \\ BATTELLLE \\ for the \\ UNITED STATES DEPARTMENT OF ENERGY \\ under Contract DE-AC06-76RLO 1830
}

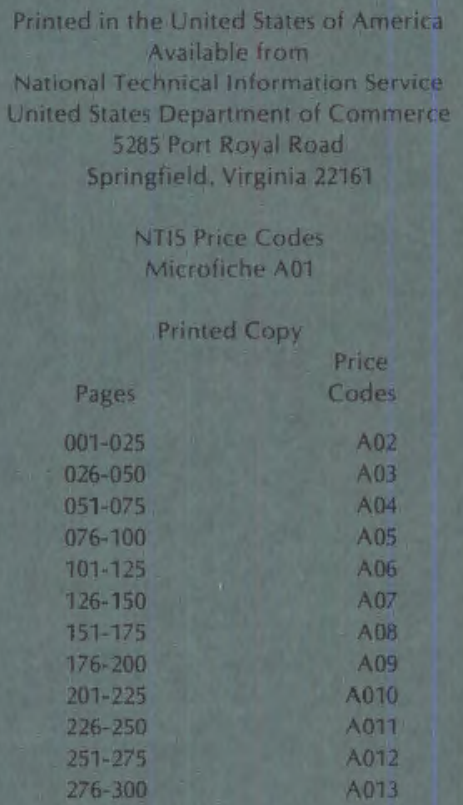


PNL -4754

$\mathrm{UL}-7]$

REVIEW AND EVALIATION OF

METALLIC TRU NLCLEAR WASTE

COASOL IOATION METHLODS

D. R. Mantgotnery

J. F. Nesbiti

August 1983

Prepared for

the U.S. Jepartment of Energy

What Contract DE-ACO6-7ERLO 1830

Pacific Horthwest Laboratory

Richland, Wiashington 99352 
-

3 


\section{ACKNOWLEDGMENTS}

This report represents the cumulative efforts of a number of individuals. The authors are particularly indebted to those individuals and/or companies who provided the material referenced and used in this report. Special thanks are due to G. A. Beitel of Rockwell Hanford Operations, J. Cottrell of AlliedGeneral Nuclear Services, and R. G. Nelson of PNL. 


\section{-}

,

" 


\section{ABSTRACT}

A study was conducted by Pacific Northwest Labaratory to identify, eyaluate, and rate consolidatian methods that could reduce the volume of metallic wastes generated in a fuel reprocessing facility. Both compaction and melting techniques were rated, and each consolidation process was evaluated based on its feasibility for handling and processing the metallic wastes produced if the Barnwell liuclear Fuel Plant were in operacion. Vacuum coreless induction melting was rated as the best consolidation method for this application. 


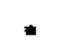


SUMMARY

The U.S. Department of Energy (DOE) established the Commercial Waste Treatment Program (CWTP) to develop, demonstrate, and deploy waste treatment technology. In this report, viable methods are identified that could consolidate the volume of metallic wastes generated in a fuel reprocessing facllity.

The purpose of this study is to identify, evaluate, and rate processes that have been or could be used to reduce the volume of contaminated/irradiated metallic waste streams and to produce an acceptable waste form in a safe and costeffective process. A technical comparative evaluation of various consoli. dation processes was canducted, and these processes were rated as to the feasibility and cost of producing a viable product fram a remotely operated radioac tive process facility.

Out of the wide varjety of melting concepts and consolidation systems that might be applicable for consolidating metallic nuclear wastes, the following processes were selected for evaluation:

- Inductoslag melting

- rotating nonconsumable electrode melting

- plasma arc melting

- Electroslag melting with two nanconsumable electrodes

- vacuum coreless induction melting

- cold compaction.

Each process was evaluaked and rated on the criterla of complexity of process, state and type of development required, safety, process requirements, and facility requirements. It was concluded that the vacuum coreless induction melting process is the most viable process to consolidate nuclear metallic wastes. 
-

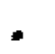




\section{CONTENTS}

ACKNOWLEDGMENTS $. \ldots \ldots \ldots \ldots \ldots \ldots \ldots \ldots \ldots \ldots \ldots \ldots \ldots \ldots \ldots \ldots \ldots \ldots \ldots \ldots, \ldots \ldots$

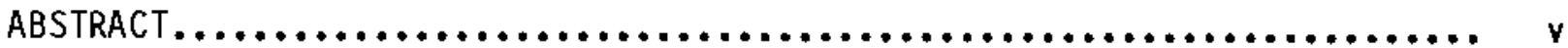

SUMMARY.......................................................... vi i

INTRODUCTION................................................. I

RESULTS, CONCLUSIONS, AND RECOMMENDATIONS...................... 7

BASES AND ASSUMPTIONS OF STUDY.............................. 11

GENERIC ASSUMPTIONS AND BASES $. \ldots \ldots \ldots \ldots \ldots \ldots \ldots \ldots \ldots \ldots \ldots \ldots \ldots, 11$

REGULATORY CONSIDERATIONS AND REQUIREMENTS $\ldots \ldots \ldots \ldots \ldots \ldots \ldots \ldots \ldots, 12$

Contamination Control.................................. 12

Radiological Protection................................ 12

Process Safety Features................................ 13

Life of Process Equipment............................. 13

Process Cell Requirements.............................. 13

General Equipment Requirements.......................... 14

FUnCtIONaL CAPABILITIES................................. 15

PROCESS MATERIAL IDENTIFICATION.......................... 16

CRITERIA FOR METHOD SELECTION AND EVALUATION.................. 17

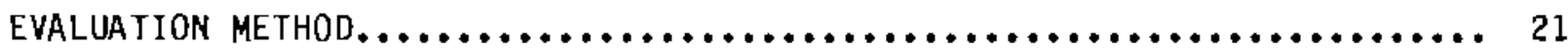

REFERENCES................................................ 25

APPENDIX A - INDUCTOSLAG MELTING................................ A.1

APPENDiX B - NONCONSUMABLE EleCtROdE MELTING....................... B.l

APPENDIX C - PLASMA ARC MELTING................................. c. 1

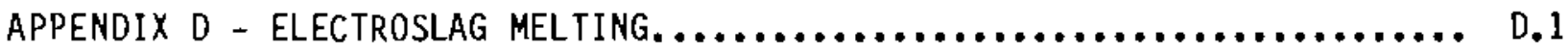

APPERDiX E - VACUUM CORELESS INDUCTION MELTING.................... E. I 
APPENDIX F - COLD COMPACTION................................. F.1

APPENDIX G - EVALUATION CHECKLIST.............................. G.1

APPENDIX H - PROCESS RATING GUIDE............................. H.1 


\section{FIGURES}

A.1 Inductoslag Melting Process - Ingot Mode....................... A,2

- A.2 Inductoslag Meiting Process - Casting Mode........................ A.2

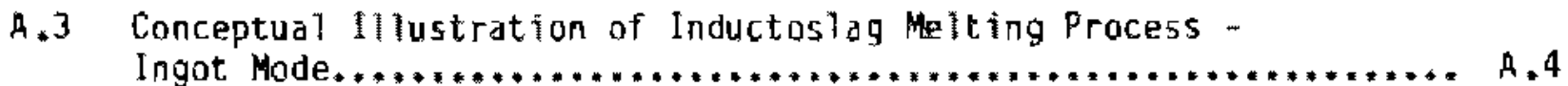

A.4 Inductaslag Melter Process Flaw Diagram........................... A.5

A.5 Inductoslag Melter Mechanical Sequence Diagram*.................. A.9

A.6 Conceptual Arrangement of Inductosiag Melt-andmpour Furnace........ A.14

A.7 Lower Elevations of Preliminary Layout for Inductos lag Furnace System............................................., .17

A.8 Upper Elevations of Preliminary Layout for Inductoslag Furnace System..................................................... A.19

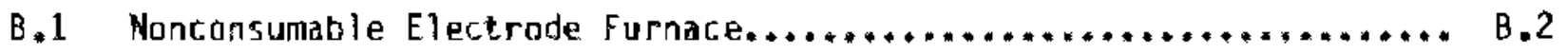

B.2 Rototrode Electrode for Nonconsumable Electrode Melting System..... B.3

B.3 Operational Modes for Nonconsumable Electrode Furnace.............. 8.4

B.4 Bateh Skull Melting by Adding 55-gal Drums of Metal.............. B.5

B.5 Batch Skull Melting with Continudus Feeding................... 8.5

B.6 Batch Skull Melting with Continuous Feeding; Melt Poured

B.7 Batch Skull Melting with Continuous Feeding; Ingot Withdrawn
From Bottom................................................. 6.6

B.8 Nonconsumable Coldwall Furnace As sembly.......................... B.8

B.9 Nonconsumable Coldwall Furnace Melt Chamber Assembly............... B.9

B.10 Batch Skull Melting with Continuous Feeding....................... B.10

B.11 Bateh Sku11 Melting; Melt Poured Into Canister................... B.10

B.12 Vacuum Pumping System......................................, B.13

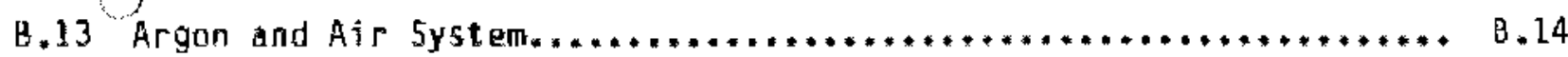

$\quad$ c.1 Plasma Arc Furnace,........................................ C.2 
D.1 Process Flow Diagram of Electroslag Melting Process................ 0.1

D.2 Electroslag Melting Furnace................................ 0.2

0.3 Electroslag Melting Furnace.................................. [.4

E.1 Cored Induction Furnace................................. E.1

E.2 Coreless Induction Furnace,................................. E.2

E.3 Bottom Pour 5tationary Crucible for Vaculim Induction Melting

E.4 Tilt-and-Pour Method for Vacuum Induction Melting Process.......... E.4

E.5 Induction Melting Coil and Crucible Modules...................... E.5

F.1 Mechanical Sequence Diagram of Cold Compaction Process............. F.3

F.2 Cold Compaction Compactor................................. F.5

F.3 Lower Level Building Layout for Cold Compaction Facility........... F.11

F.4 Upper Level Building Layout for Cold Compaction Facility.......... F.13

F.5 Isometric View of cold Compaction Facility...................... F*15 


\section{TABLES}

1 Composite Rating Matrix for Consolidation Pracesses............... 7

2 Annual MCP Metallic Throughput................................ 17

3 Criteria for Process Evaluation................................. 19

4 Criteria and Wefghting Factors for Process Evaluation............ 23

A.1 Major Remote Equipment for Inductoslag Melting Process............. A.8

A.2 Utilities, Seryices, and Materials for Inductoslag Melting Process........................................................ A.16

A.3 Inductoslag Ingot Mode System Evaluation - Evaluator A............ A.32

A.4 Inductasiag Ingot Mode 5ystem Evaluation * Evaluator B............. A.33

A.5 Inductoslag Ingot Mode System Evaluation - Evaluator 0........... A.34

A.6 Inductoslag Casting Mode 5ystem Eyaluation - Evaluator A........... A.35

A.7 Inductoslag Casting Mode System Evaluation - Evaluator B.......... A.36

A.8 Inductoslag Casting Mode System Eyaluation - Evaluator C.......... A.37

A.9 Induetoslag Casting Mode System Evaluation - Evaluatar D.,........, A.38

B.1 Utilities, Services, and Materials for Nonconsumable Electrade
Melting Process.............................................. B.13

B.2 Nonconsumable Elect.rode System Evaluation - Evaluator A........... 8.20

B.3 Nonconsumable Electrode System Evaluation - Evaluatar B........... B.21

B.4 Nonconsumable Electrode System Evaluation - Evaluator C.......... B.22

B.5 Nonconsumable Electrode System Evaluation - Evaluator 0.......... B.23

C.1 Utilities, Services, and Materials for Plasma Arc Melting

Proces $5 . \ldots \ldots \ldots \ldots \ldots \ldots \ldots \ldots \ldots \ldots \ldots \ldots \ldots \ldots \ldots \ldots \ldots \ldots \ldots \ldots \ldots \ldots \ldots, \quad[.4$

C.2 Plasma Arc System Evaluation - Evaluator A..................... C.B

C.3 Flasma Are System Evaluation - Evaluator B..................... C.9

C.4 Plasma Arc System Evaluation - Evaluator C........................ C.10

C.5 Plasma Are System Evaluation - Evaluator 0...................... C.11 


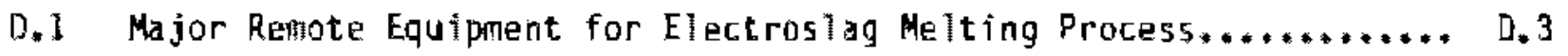

D.2 Ithlities, Services, and Materials for Electroslag Melting

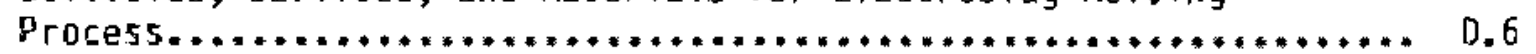

D.3 Electroslag System Evaluation - Evaluator A.................... 0.11

D.4 Electroslag System Evaluation - Evaluator B................... 0.12

0.5 Electroslag System Evaluation - Evaluator C.................. 0.13

0.6 Electroslag System Evaluation - Evaluator D................... 0.14

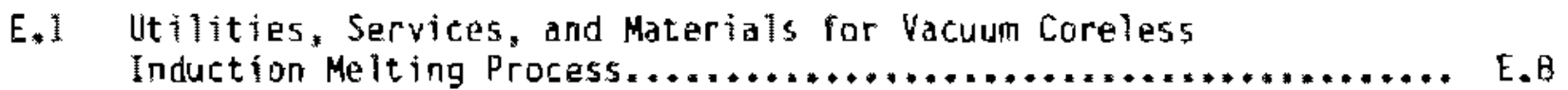

E.2 Coreless Induction 5ystem Evaluation - Evaluator A.............. E.12

E.3 Coreless Induction System Evaluation = Evaluator B..........**** E*13

E.4 Coreless Induction System Evaluation - Evaluator C.............. E.14

E.5 Coreless Induction Systent Evaluation - Evaluator D............... E.15

F.1 Equipment Description for Cold Compaction Facility.............. F.10

F*2 Cold Compaction Facility Description...***.................. F.17

F,3 Utility, Services, and Materials for told Compaction Process....... F,19

F.4 Cold Compaction System Evaluation - Evaluator A.*..........**** F.23

F.5 Cold Compaction System Evaluation - Evaluator B................ F.24

F.6 Cold Compaction System Evaluation - Evaluator C................ F.2S

F.7 Cold Compaction System Evaluation - Evaluator D................. F.26 


\section{INTRODUCTION}

The safe disposal of nuclear wastes is essential for the continued use of nuclear energy in the United States and abrodd. In the United States, the basic goal has been to develop and use waste forms and environments that strictly limit the amount of radioactivity that can ever reach the biosphere. In pursuing the nuclear waste management goal, it will be necessary to produce acceptable waste form products for several specific wastes using feasible and cost-effective processes. The waste form process includes the isolation or solidification of that particular waste, containment, transportation, and longm term storage or disposal.

Hetallic wastes are generated when spent reactor fuel is reprocessed. The reprocessing of light-water reactor (LWR) fuels typically begins with the removal of the nonfuel-bearing nozzles and end fittings from the fuel bundle assembly. The rematinder of the assembly ffuel pins or tubes, shrouds, spacers, and other structural members) is sheared or cut into short lengths so that the fuel can be leached out of the tubes in an acid dissolver. The residues from the acid leach process are identified as hulls and include the short lengths of the fuel tubes or cladding, the end fittings, and assorted springs, flow channels, and other metallic fuel bundle components. The hulls carstitute - 13\% of the total waste volume generated in a spent fuel reprocessing facility and $n 80 \%$ of the total metallic waste volume (Anderson, Carr, and Mitchell 1982). These materials have a bulk density of $m 1.1 \mathrm{~kg} / \mathrm{h}$; however, this density can be increased and the volume can be reduced by a factor of six using any ane of several methods.

Other contaminated metallic waste streams that will also be generated in a spent fuel reprocessing facility consist of failed or obsolete process equipment and equipment scrap. With proper facilities to reduce the size of large pieces of falled equipment and scrap, it is anticipated that a volume reduction of $10: 1$ could be achieved if these metallic wastes were meited.

High-level general process trash (HLGPT) is a remotely handled cransuranic (TRU) waste stream. If segregated, metalijc components such as failed motors, 
pumps, valves, pipes, tubing, and miscellaneous metal items could be consolidated to reduce their volume. Similar metallic items will also be present in the contact-handled TRU waste separated from low-level general process trash (LLGPT)*

Transport and burial of radioactive wastes is expensive. Since a major portion of these costs is direct function of volume, there is an obvious economic incentive for volume reduction. Thus, the cost to achieve the maximum feasible reduction in volume may be more than offset by reduced transportation and repository cos s.

Nearly all wastes from a spent fuel reprocessing plant may be processed for elther safety or economic reasons or both. The size and form of the waste could impact the federal repository, and repositary acceptance criteria will impact the waste handling processes in a reprocessing plant. Consideration of both the reprocessing plant and the repository requirements and initations will be mutually beneficial and will ald in the safe disposal of radiactive wastes by an overall cost-effective process.

The main objective of all waste imobilization prograns is to contain the radianuclides until thetr activity has decreased to acceptable or allowable levels. The purpose of this study is to ident fy, evaluate, and rate processes that have been or could be used to 1) reduce the volume of contaminated/ irradiated metallic wastes and 2) produce an acceptable waste form in a safe and cost-effective process. It specifically addresses the metallic wastes that are antictpated from the operation of the Barnwel1 Nuclear Fuel Plant (BNFP), Barnwell, South Caralina. Since tit is neither practical nor desirable to develop several parallel process concepts to the level where any one could be applied in a product on factility, it is the objective of this study to 1) perform a technical comparative evaluation of various consolidation processes and 2) rate these processes based on the feasibiluty and cost of producing a viable product from a remotely operated radioactive process facility.

The U*S. Department of Energy (DOE), through its Office of Nuclear Fuel Cycle, established the Commercial Haste Treatment Progran (CWTP) at Pacific 
Northwest Laboratory (PNL). (a) The god of the CWTP is to develop, demonstrate, and deplay waste treatment technology. One of its abjectives 15 to estabish acceptable waste forms for storage and disposal. The scope af this particular study is to identify, evaluate, and rate consolidation methods to reduce the volume of metallic wastes generated in a fuel reprocessing facility. It includes the feasibility of operating a production-scale process in a radioactive environment that requires remote operation and matintenance. Thus, this study pertains only to the technical and engineering aspects of the candidate methods in respect to their suitability as production-scale operations with radioactive process materials. It is also limited to consideration of only the metallic wastes produced in the operation of the BNFP.

The projected large costs for transportation and burial of radioactive wastes will be a direct function of volume and activity level; thus, it was considered to be beyond the scope of this program to include a no-treatment process (i.e., segregate, identify, and containerize). Methods and processes to decontaminate the subject metalic waste streams so that the resultant products are not contaminated or are in a lower classification fontact handled versus remote handled) were also not considered.

There are several methods that can be used to consolidate the wide range metallic wastes. Basically these methods can be grouped into two general catem gories: compaction and melting. Methods that have been used to consolidate metals include induction melting, electric arc melting, hot pressing, and cold compactian. Studies and research have been conducted by AlliedmGeneral Nuclear Services (AGNS) on handling and staring wastes generated in the operat fon of the BNFP. In earlier conceptual designs, mechanical or cold compaction processes were considered to reduce the volume of spent fuel hulls (AGMS 1978; Anderson et al. 1979). Based on continuing research conducted at PNL, another densification pracess--Inductoslag melting--was identified in a preconceptual design (Butcher et al. 1980).

(a) Operated for DOE by Battelle Memorial Institute. 
A wide varlety of melting concepts or furnace types might apply for consolidating metallic nuclear wastes. The following 24 melting systems or types of furnaces have been or are being used in various industries and were selected for preliminary evaluation:

- Induction Melting

Induction

Vacuum coreless induction

Cored induction

Conventional air coreless jnduction

Cont inuous induction melting and casting

Crucible coreless induction

Crucible coreless induction lift-swing coill

Induct os lag

- Electric Are Melting

Electric are

Mechanically rotated nonconsumable electrode

Magnetically rotated nonconsumable electrode

Carbon electrode

Tungsten electrode
Melting materid by means of an electric current that flows through the metal by electromagnetac induction.

Melting by induction in a vacuum; coreless means that the induction cotl surrounds the netal charge.

The induction coll is surrounded by molten metal.

Melting by induction in an air atmosphere.

Meiting by induction to supply a continuous stream of malten metal to the casting mold.

Melting by induction in a preformed freestanding crucible.

The induction coil is lifted up and away from the crucible after melting.

Induction melting in a segmented watermcooled copper cructble with a slag as thermal and electrical insulation.

Melting by means of an electric arc generated between the electrode and the melting charge.

Arc is generated on a mechanically rotated water-cooled electrode.

Arc is magnetically rotated on a watercooled electrode.

The single electrode is carbon or graphite. The single electrode is tungsten. 
Consumable electrode

Indtrect are

Dì rect carbon arc

Indipect rocking arc furnace

- Plasm Arc Melting

plasma arc

Hollow electrode

Plasma induction

- Electron Beam Melting

- Electroslag Melting

Electroslag melting with two nonconsumable electrodes

- Resistance Melting
The single electrode is the material to he melted and is consumed.

The charge is melted by radiant heat from the arc.

Each of three vertical carbon electrodes are connected to one phase of a three-phase alternating current circuit. Melting is accomplished by the arc generated between the electrodes and the charge.

The charge is melted by radiant heat from the arc, and the furnace is rocked during melting.

Melting by a plasma arc that is generated by ionizing a gas passing through an electric arc.

Gas passes through a hollow electrode and is then jonized in the arc formed between two electrodes ar between an electrode and the charge.

Melting by plasma arc the molten pool is stirred by an induction coil.

Melting by a heam of electrons produced by an electron emitter and targeted on the metal to be melted.

A preformed consumable electrode is melted through a slag batr inta a water-cooled steel or copper mold. The electrode is melted by thermal conduction from the slug where heat is generated by resistance to the passage of electric current.

Explaned in Appendix D.

Melting by elements that are heated as a result of their resistance to the passage of electric current. 
When the general requirements for selecting consolidation methods are reviewed, it becomes apparent that a melting system should be capable of aper: ating in a contained atmosphere and should use a crucible made of material suitable for melting zírconium. These two criteria basically eliminate any melting system that incorporates an oxide refractory crucible or one that nperm ates in an air atmosphere. Not being able to use an oxide refractory is probably the single most limiting factor in the selection of a potential melting system for the application considered in this document. Oxide refractories require routine maintenance such as patching and periodic replacement, which would be very time consuming due to the limited access and the remote maintenance dictated by the hot cell installation. The use of oxide refractories would also generate large amaunts of secondary waste. Refractory systems would not allow the melting of zirconium and titanium due to the metal/crucible reaction.

These limitatians removed a number of the above melting systems from furm ther consideration. This elimination is supported in a previous study and rating done by Nelson on the melting of Zircaloy hulls and residual fuel bundle scrap (stainless, Inconel, etc.) (velson, Schlienger, and Tiesenhausen 19r6).

Thus, the scope of this study was limited to the following melting systems that have the most potential for application to the remote consolidation of metallic nuclear wastes:

- Inductosuag melting

- rotating nanconsumable electrode melting

- plasma arc melting

- Electroslag melting witr two nanconsumable electrodes

- vacuum coreless induction melting*

The cold compaction system that was developed at Barnwell for the consolidation of spent fuel hulls was also evaluated in this study. Thus, systems that fall into the two general consolidation categories are assessed and evaluated. 


\section{RESIJLTS, CONCLUSIONS, AND RECOMMENDATIONS}

The purpose of this study was to identify, evaluate, and rate consolidation methods or processes that could reduce the volume of metallic wastes and produce an acceptable and viable waste form in a safe and cost-effective remotely operated radioactive processing facility. Each process was evaluated based on its feasibility for handing and processing the metallic wastes produced in the operation of the BAFP.

The seven processes were evaluated based on the following criteria: comm plexity of process, state and type of development required, safety, process requirements, and facility requirements. The ratings and numerical values shown for each criterla are the results of independent evaluations made by individuals with a broad base of experience in radioactive waste processes, remote handing, remote process facility operation, and/or metal melting and casting. The numerical ratings for each process by principal criterias a total rating for each, and its ranking based on its total numerical rating when cornpared with the other processes are presented in Table 1. More detailed summaries of the composite numerical ratings assigned to each process by the evaluam tors are included in Appendices A through $F$.

TABLE 1. Composite Rating Matrix for Consolidation Processes

\begin{tabular}{|c|c|c|c|c|c|c|c|}
\hline & $\begin{array}{l}\text { Inductos log } \\
\text { witing } \\
\text { (1nowt) }\end{array}$ & $\begin{array}{c}\text { Industoslag } \\
\text { Hot ing } \\
\text { Schst tng }\end{array}$ & $\begin{array}{c}\text { Honcons useb la } \\
\text { Electrode } \\
\text { ke Itlng }\end{array}$ & $\begin{array}{l}\text { Ptestio } \\
\text { Arc } \\
\text { Anting }\end{array}$ & $\begin{array}{c}\text { Eloctroslag } \\
\text { M Iting }\end{array}$ & $\begin{array}{c}\text { Voculum } \\
\text { cardies } \\
\text { Induction } \\
\text { mitling }\end{array}$ & $\begin{array}{c}\text { Cold } \\
\text { Competion }\end{array}$ \\
\hline Appendly & $A$ & $A$ & 9 & $\mathrm{C}$ & D & $E$ & $F$ \\
\hline \multicolumn{8}{|l|}{ Complextty of } \\
\hline process & 302 & 302 & 359 & 320 & 254 & 435 & 320 \\
\hline \multicolumn{8}{|l|}{ Stato atid tTpe } \\
\hline of deve lopnent & 240 & 254 & 264 & 244 & 210 & 294 & 27 \\
\hline Safaty & 227 & 228 & 212 & 222 & 210 & 262 & 292 \\
\hline \multicolumn{8}{|l|}{ Process } \\
\hline regulranents & 157 & 156 & 217 & 189 & 140 & 226 & 247 \\
\hline \multicolumn{8}{|l|}{ Focility } \\
\hline requlrements & 210 & 190 & 195 & 192 & 202 & 240 & 168 \\
\hline Toto a roting & 1136 & 1190 & 1247 & 1167 & 1016 & 140 & 1241 \\
\hline Renk ing & 6 & 4 & 2 & $s$ & 7 & 1 & 3 \\
\hline
\end{tabular}


Vacuum coreless induction melting was rated as the best process to reduce the metallic wastes generated when spent reactor fuel is reprocessed. The other processes ranked in the following order: nonconsumable electrode melting, cold compaction, Inductoslag melting (casting mode), plasma arc melting, Inductoslag melting (ingot mode), and Electroslag melting.

The composite process ratings were very close for some of the criteria. The ratings for the nonconsumable electrode and cold compaction processes were essentially the same and there were less than 100 total rating points variance between the second and sixth processes. The basic advantages and disadvantages for the individual processes are noted below:

- Inductoslag melting (ingot and/or casting mode) - The number of ingots or pours that was assumed to be required due to the apparent limited diameter of the crucible had a definite negative impact on the rating of these melting methods. If larger diameter crucibles prove to be feasible, the Inductoslag process and the casting method in particular could be ranked much more favorably.

- nonconsumable electrode melting - This melting method ranked neither very high nor very low; thus, it received a good overall rating. The water source above the surface of the molten pool is a safety concern, and the complexity of the electrode may impact operations and maintenance in a remote hot cell installation.

- plasma arc melting - Ingot withdrawal is the only practical method for this process due to the limited molten pool depth, which adds to process complexity because both ingots and canisters must be handled.

- Electroslag melting - The need to produce ingots and to require several ingots to fill a given canister resulted in a generally low rating for this process.

- vacuum coreless induction melting - This process received very good overall ratings for all the criteria. Additional secondary wastes may be a concern because crucible liners need to be changed after a few heats. 
- cold compaction - Although this process has fewer requirements than the various melting processes, it does require consuderably more handing while the containers are being fllled. This fact and the -50\% density of the compacted wastes detracted from its rating.

Since a ful 1 -scale remotely operated system to consolidate nuclear metalIIc waste by melting does not exist lat least in the united states), it is recommended that a large-scale cold mockup facllity be established to refine and test the melting systen recomended by this study prior to production operation. The mockup facility could also be used to test other similar equipmert, and th wuld be a valuable tool for troubleshooting subsequent production problems. 
-

* 
A11 wastes from the BNFP will be processed through the waste processing center (WPC). This facility will house the processes and systems required to consolidate the various solid and liquid wastes. It will contain the processes and equipment required for the solidification of high-level liquid wastes (HLLW), volume reduction or compaction of fuel hulls and metallic wastes, volume reduction of HLGPT, volume reduction of LLGPT, and equipment volume reduction and decontamination as well as other waste processing functions. These processes will be arranged in the WPC so they can function independently. Feed streams, effluents, and final products will be integrated with the various processes and facilities in the remainder of the fuel reprocessing plant.

\section{GENERIC ASSUMPTIONS AND BASES}

- Commercial reprocessing will be done, and nuclear wastes will be transported by commercial carriers to and placed in federal repositories.

- Due to the projected costs of transporting and disposing of radioactive wastes and because of regulatory requirements, a spent fue 1 reprocessor will process the radioactive wastes. The processing will generally be of two types: 1) volume reduction of wastes to reduce costs (for example, compaction, cutting, or melting) and/or 2) changing the form of the wastes to meet general safety regulations (for example, solidification).

- Mechanical compaction or melting technology could be used to densify the fuel hulls and the metallic wastes generated in a spent fuel reprocessing plant.

- Facilities will be available to reduce the volume of large pieces of failed equipment to a size that can be consolidated.

- Nozzles and end fittings will not be segregated from other fuel bundle components as they are sheared. 
- The consolidation process will yield a waste form product that is close to maximum theoretical density and that is of a shape and size that can be cost effectively contained, shipped, and placed in a federal repository.

- Although decontamination by smelting has potential, it was not considered in this study.

REGULATORY CONSIDERATIONS AND REQUIREMENTS

The WPC will be subject to licensing by the li.S. Nuclear Regulatory Commission (NRC); therefore, it will conform to applicable regulatory guides and criteria for fuel reprocessing plants and nuclear facilities. The facility will also be subject to the requirements of the National Environmental Policy Act (NEPA); and the facility and equipment must be in accordance with other federal, state, and local codes, regulations, and standards. Contamination Control

The metallic consolidation process (MCP) will be designed to confine radioactive contamination within processing vessels by several methods:

- Areas of higher contamination potential will be isolated or separated from areas of lower contamination potential.

- Ventilation air will flow from areas of lower contamination potential to areas of higher contamination potential.

- Areas that could become contaminated will be designed to contain any spilled solutions or solids or to direct the flow of such spills to areas of higher contamination potential.

Radiological Protection

The MCP will be designed and operated so that personnel radiation exposure will be controlled to as low as reasonably achievable (ALARA) levels. Effluent releases from the process will be monitored for radionuclide content and processed in the WPC as required. The process facility will be capable of ceasing or containing the effluent flow under all normal conditions and all designbased accident conditions. 


\section{Process Safety Features}

Process protection systems will assure that acceptable operating design limits are not exceeded and will detect potentially hazardous conditions and malfunctions. Should a potentially hozardous situation be detected, hazardsuppression systems will be automatically activated where practical.

\section{Life of Process Equiment}

The MCP will have a useful operation life of 30 yr and will be designed and constructed according to the following design considerations:

- Eyery component will be designed for maintenance or replacement taking into consideration its remote or nonremote operating environment and design-based accident scenarios.

- Every component will be designed, procured, fabricated, and operated in accordance with established quality assisrance requirements.

Process Cel1 Requirements

A11 operations whin the process cell will be performed remotely. Process cell operations will be performed and/or monitored from a central control room; however, control may be selectively exercised from local consoles that will be supplemented by viewing windows, closed circuit televisians, and/or periscapes. The control consoles will also be equipped with instrument systems to detect equipment malfunctions and fluctuations in the properties of the feed materials and the process. Routine adjustments and the rerouting of process materials will be done from the consoles. Other adjustments or malfunctions may be corrected using manipulators or other devices.

The process cell walls will be thick enough to reduce the radiation dose rate to ALARA levels. The cells will be lined with Type 304L stainless steel to aid in decontamination and decomissioning and to protect the walls from corrosive chemicals and vapors.

Equipment on process cell walls will be mounted on ears, yokes, or racks; and equipment on the floor of the cell will be mounted on guide racks or dunrages. The placement of equipment will depend on the equipment and how it can 
be handled in the cell. The width and height of the cell will be determined by the size of the equipment and the remote-maintenance and remote-servicing requirements.

Television cameras will be strategically located to provide coverage for operating, inspecting, and repairing equipment. Floor and wall space will be provided in each process cell for storing tools and other maintenance equipment. Space will also be provided between the process equipment in the cell for handling equipment and for moving items.

\section{General Equipment Requirements}

Remote operations require that all process equipment and equipment for handling process materials be automated or mechanized and remotely operable. Process cell equipment will be designed for simplicity, reliability, and easy maintenance. The use of master-slave and electromechanical manipulators for the routine remote operation of process equipment will be minimized. Process cell equipment will be fabricated from materials tiat are resistant to corrosion, radiation damage, and processing conditions.

The modular process equipment will be installed and removed remotely using a crane hoist and/or manipulators or other devices. Equipment modules that are expected to fail within the lifetime of the facility will be remotely replaceable without removing other major equipment. The dimensions of the modules will be controlled. Alignment dowels, studs, and fixed mounting trunions will insure exact positioning of equipment and components.

Auxiliary equipment that will require contact maintenance (for example, feeders, welders, and mass spectrometers) will be located outside the cells if possible. Air locks, antibackflow devices, and block valves between the in-cell and out-of-cell equipment will insure safe operations.

Processing equipment surfaces normally exposed to process materials will be isolated from the cell environment to the extent practical. The contained areas will be maintained at pressures lower than those in the cell by connecting the contained areas to the ventilation or off-gas system. Process 
equipment that may be exposed to internal pressures exceeding the capacity af the ventilation or off-gas system will be fitted with devices that permit the safe release of pressure to the cell.

Processing equipment will be designed to minimize the buildup of process material in the equipment. Equipment that is prone to internal buildup of material will be fitted with sensors to monitor bulldup. Process equipment that may be exposed to internal fire and/or explasive gas mixtures will be fitted with montoring instruments and suppression devices.

FUNCTIONAL CAPABILITIES

All radioactive metallic wastes from the BNFP will he processed through the MCP in the WPC. The MCP shall be capable of processing the nonfuel-bearing residues from the nitric acid leaching of chopped fuel assemblies that are assumed to have the following irradiation history:

$\begin{array}{ll}\text { Burnup } & 29,000 \mathrm{MWd} / \mathrm{ATU} \\ \text { Spec. power } & 32.5 \mathrm{HW} / \mathrm{MTU} \\ \text { Initial enrichment } & 2,8 \% \\ \text { Reactor on } & 80 \% \\ \text { Age at repracessing } & 3 \mathrm{yr}\end{array}$

The reference fuel cladding is composed of the following major constituents:

\begin{tabular}{lc} 
Element & $\mathrm{kg} /$ MTU \\
\cline { 2 - 2 } Zirconium & 283.0 \\
Iron & 17.1 \\
Nickel & 9.9 \\
Chronium & 7.0 \\
Tin & 4.1 \\
Niobium & 0.8 \\
Cobalt & 0.04 \\
Other & 2.1 \\
Tatal & 324.0
\end{tabular}

The retallic wastes segregated from HLGPT will also be contaminated with particulates from the spent fuel processing operation and are considered to contain radioactive isotopes in the sane percentages as the fuel but in mach 
smaller quantities. This material and falled processing equipment and metallic scrap (primarily stainiess steel) will also be processed through the MCP. The majority of falled equipment and scrap will be classified as noncontact TRU waste because of its level of contamination although there may also be some material in the contact TRU waste category.

\section{PROCESS MATERIAL IDENTIFICATION}

The following material will be processed through the NCP on an annual basis:

- noncontact TRU waste (greater than $50 \mathrm{mrem} / \mathrm{h}$ )

a) hulls - These materials constitute a high-volume waste representing $222 \%$ of the original fuel bundle weight with a bulk density of $-1.1 \mathrm{~kg} / \mathrm{l}$. As recovered from the dissolver, these hardware residues represent $-325 \mathrm{~kg} / \mathrm{t}$ of uranium and consist of 70 to 80 wto Zircaloys 12 to 22 wt stainless steel, and 8 ht inconel.

b) failed process equipment and equipment scrap of varying size (mostly stainless steel)

c) HLgPT - If segregated, the metallics would consist of failed motors, valves, pipes, and assarted metallics plus some arganics and ceramics.

- contact TRU waste (less than $50 \mathrm{mrem} / \mathrm{h}$ )

a) failed equipment, motors, pumps, pipes, valves, and tools plus organits and ceramics

b) LLGPT - If segregated, the metallics would include tools, tubing, valves, and assorted metallics plus some organics and ceramics.

Based un reports by Anderson, Carr, and Mitchell (1982) and Keeley (1977), the volume and weight of the various metais assumed to be generated in a 1500-MTU processing plant and processed in the MCP are shown in Table 2. Volume reduction ratios of $6: 1$ and $10: l$ were assumed for hills and other metallics, respectively. 
TABLE 2. Annual MCP Metallic Throughput

\begin{tabular}{|c|c|c|c|c|}
\hline $\begin{array}{l}\text { Type of } \\
\text { Waste }\end{array}$ & $\begin{array}{c}\text { Amount } \\
\text { Before } \\
\text { Processing } \\
\text { ft }^{\text {Bing }}\end{array}$ & $\begin{array}{l}\text { Amount } \\
\text { After } \\
\text { Meltjng, } \\
\mathrm{ft}^{3} \\
\end{array}$ & $\begin{array}{c}\text { Weight of } \\
\text { Material, } \\
\text { it (kg) }\end{array}$ & $\begin{array}{l}\text { Mumber of } \\
\text { Canister } \$ \text { a) } \\
\text { Produced }\end{array}$ \\
\hline Hulls & 16,875 & 2,812 & $\begin{array}{c}1,197,500(b) \\
(543,100)\end{array}$ & 112 \\
\hline $\begin{array}{l}\text { Fail led } \\
\text { equipment }\end{array}$ & 2,400 & 240 & $\begin{array}{l}117,800(\mathrm{~b}) \\
(53,400)\end{array}$ & 10 \\
\hline HLGPT $(C)$ & 940 & 94 & $\begin{array}{l}43,900(d) \\
(19,900)\end{array}$ & 3 \\
\hline $\operatorname{LLGPT}(c)$ & 1,220 & 122 & $\begin{array}{l}56,900^{(d)} \\
(25,800)\end{array}$ & 4 \\
\hline
\end{tabular}

(a) Full canister is $24 \mathrm{in.} \mathrm{in} \mathrm{diameter} \mathrm{by} 10 \mathrm{ft}$ long $\left(31.4 \mathrm{ft}^{3}\right)$.

(b) Based on 0.237 ib/in. Zircaloy and $0.2841 \mathrm{~b} / \mathrm{in}^{3}$ steel.

(c) HLGPT - high-level general process trash; LLGPT - low-level general process trash, Mxed metals: staînless steel, carbon.

(d) Based on $0.2701 \mathrm{~b} / 3 \mathrm{~s}^{3}$ mil xed metals.

\section{CRITERIA FOR METHOO 5ELECTION AND EVALUATION}

Before any method can be considered as applicable to consolldate metallic wastes generated in a remotely operated and maintained production-scale fuel reprocessing facility, it mast meet the following general requirements:

- capable of handling or meltung all common metals and/or alloys including reactive metals such as zirconium with a limited metal/crucible reaction

- relatively simple to operate and maintain in a remote application

- relatively safe

- littie or no secondary waste generation

- well-developed basic concept

- maximum containment of off gases and radionuclides

- atmosphere conducive to handling zirconium 
- compatible with production throughput and product requirements

- system size and configurations compatible with facility limitations.

The following basic guidelines were also established for the evaluations:

- Other than product density and integrity before placing in a container, differences in the properties of the products are not to be considered a major factor in the assessment.

- Both process and equipment considerations are to be taken into account.

- Qualitative judgments are to be made as to the level and scope of development required to place the process in production in the remote mode.

The solidification processes that were identified in this report are described in Appendices A through F; they were considered and used as the bases of the comparisons. These data were supplemented by various publications, original manufacturers' data, and information available on the BNFP processes. An approach for engineering feasibility evaluation of processes to solidify nuclear high-level wastes (E. R. Johnson 1980) was used to develop the criteria shown in Table 3.

The principal ground rules for the processability analysis are summarized below:

- The solidification method must be capable of being designed for and operable using remote operation and maintenance techniques.

- All criteria for the safe handling of radioactive materials must be adhered to.

- The process must be capable of consolidating a variety of metals and/or alloys (including reactive metals) with an acceptable metal/crucible reaction.

- Ways and means to perform all process steps are to be at least envisioned. Undefined equipment required to perform a process step remotely shall be considered as a development item. 
TABLE 3. Criteria for Process Evaluation

Complexity of Praces 5

Material handling

Consolidation mode

Maintenance considerations and equipment reliability

Controls and operation

Adaptability to remote operation

Number of process steps

Feasfbility for production

Feed Iimitations

State and Type of Development

Process

Equi pment

Type of development

Scale of development

Development time requíred (from initiation of program)

Safety

Stability and atmosphere of process steps

Pyrophoricity, exothermic, and explasion considerations

Personnel radiation exposure

Process Requirements

Secondary wastes and off gases

Production capacity

Process additives and auxillary materials

Process versatility and control

Quality assurance

Utilitues (air , power, water, etc.)

Manpower

Facility Requirements

Noncontact facilities (remote)

Contact facllities (hands on)

Estimated capttal cast

- Radioactive liquilds ar gases should be transferred at pressures negative to cell atmosphere.

- Each method mast be capable of handling the applicable type and quantity of waste stream feed, 
- Pracessing equipment should have built-in flexibility jn size and operability to handle reasonable changes in waste stream composition or content.

- Services, power, and maintenance requirements are to be considered and shall be assessed if above or below specified standara.

- Methods for accident recovery (for example, melt throughs or spills) must be defined. 


\section{EVALUATION METHOD}

The rating system used for the analysis of these consolidation methods consisted of the five general categories:

- complexity of process

- state and type of development

- safety

- process requirements

- facility requirements.

Checkpoints or questions similar to those shown in Appendix $G$ were then developed for each of the categories and used to compare the consolidation prom cesses. This system met the objectives of having a rating system that was 1) quantifiable, 2) sufficiently comprehensive to delineate differences between the consolidation methods, and 3) simple and understandable,

The approach used in this study is simlar to the approach used to evaluate candidate processes for the solidification of HLLW from irradiated fuel reprocessing (a) and the approach used to evaluate various ways to coat highlevel waste form particles (0ma et al. 1981). E. R. Johnson, Oma a and Nesbutt considered only the process feasibility, as does this report; the other two evaluations considered both process aspects and product characteristics.

The evaluation criteria, the scoring method, and the weighting factors were developed through a consensus process involving personnel with a broad base of experience in radioactive waste processes, remote facility operation, and metal melting and casting. The major criteria categories and the percent weighting that was used were:

\begin{tabular}{lr}
\multicolumn{1}{c}{ Criteria } & Height \\
\hline Complexty of process & 30 \\
State and type of development & 20 \\
Safety & 20 \\
Process requirements & 15 \\
Facility requírements & 15 \\
& 100
\end{tabular}

(a) Stone, Goforth, and Smith 1979; E. R. Johnson 1980; Nestitt and Treat 1980; Dunson et al. 1982) 
The first criterion-complexity of process--represents the difficulty of operating a reliable process in a remote production facility. It is clearly the most crucial measure of the difficulty that may be involved in transforming a conceptial or pilot mplant operation to a successful remote production. An operation that can be conducted in a few steps, use equipment with the simplest and fawest moving parts, and be reliably montored and controlled has the highest probability of success. Accordingly, the rating scales reflect higher val m ues for simpler procedures and the weighting factor for this group of criteria (30\%) is targer than that for any other group.

The state of development of the process and its equipment is important because the fewer linknowns present at any time will enhance the desirable outcome. The identification and magnitude of the required developmental efforts are important aspects in assessing the probability of future successful operations.

Safety will be, of course, a requisite of any process findlly adopted. The safety rating is not 50 much an assessment of whether or not the process can be operated safely as it is an assessment of the degree of precaution that will be required in the design, construction, and operation to achieve the necessary safety.

Process requirements and facility recuirements are a measure of the services required to support the process, the manpower to operate it, and the factlities required to house the operations. Thus, they provide a relative ineasure of required costs.

Each major category was divided into subcriteria, and the total weighting factor was distributed anong the subcriteria. For each subcriterion, a rating scale from 1 to 10 was devised, and a set of qualitative descriptions was developed to define levels within each subcriterion and to serve as a uniform rating guide for all methods under consideration. The categories and their ratings are shown in Table 4. The process rating guide is presented in Appendix $H_{*}$ 
TABLE 4. Criteria and Weighting Factors for Process Evaluation

Complexity of Process

Factor Weighting

5ub Total

Material Handling 5

$\begin{array}{lr}\text { Consolidation Mode } & 5 \\ \text { Maintenance Considerations and } & 12\end{array}$

Equipment Reliability

Controls and Operation

Adaptability to Remote Operation 15

Number of Process Steps 5

Feasibility for Production 5

Feed Limitations 5

State and Type of Development 40

Process 5

Equipment 10

Type of Development 10

Seale of Development 10

Development Time Required (from 5 initiation of program)

$\underline{\text { Safety }}$

40

Stability and Atmosphere of Process 5teps 10

Pyrophoricity, Exothermic, and 20

Explosion Considerations

Personnel Radiation Exposure 10

Process Requirements 30

Secondary Wastes and of $f$ Gases 5

Production Capacity 4

Process Additives and Auxiliary Materials 5

Process Versatility and Control 5

Quality Assurance 3

Utilities (air, power, water, etc.) 3

Manpower

Facility Requirements

Noncontact Fachlities (remote) 10

Contact Facilities (hands-on) 10

Estimated Capital cost 10 
-

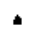

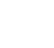




\section{REFERENCES}

Allied-General Nuclear Services. 1978. Studies and Research Concerning BNFP: 5 tarage and Handling of Wastes from Uranium Fuel Processing Alternatives. MGHS-1040-3.3-34, Barnwell, South Carolina.

Anderson, K, J, et al, 1979. Studies and Research Concerning BNFP: Engineering Evaluations of Wastes Handling and Storage Facilttes. AGNS-359004.2-26, Altied-General Nuclear Services, Barnwell, South Carolina.

Anderson, K* J., H. H. Carr, and R. C. Mitchell. 1982. ENFp Waste Characterization and Waste Treatment. PNL-3136/FRm01, Allied-General Nuclear Services, Barnwel], South Garolina.

Butcher, J. R., et a?. 1980. Studies and Research Concerning BNFP: Report on Engineering Evaluation of processing Alternatives. RtNS-35900-3.3-80, Allied-General Wuclear Services, Barnwell, South Carolina.

Dunson, J. B*, et al. 1982. Assessment of Processes, Facilities and Costs for Alternative Solid haste forms for Immobillzation of SRP defense wastes. DP-1625, E. I, du Pont de Nemours and Company, Inc, then, South Carolina.

E* R. Johrison As5ociates, Inc. 1980. Preliminary Evaluation of Rlternative Waste Form solidification Processes, Volume I: Evaluation of the Processes. PNI $\rightarrow 3477$, Pacific Northwest Laboratory, Richland, Washington.

Keeley, R. B. 1977. "Description of Law-Level Radioactive Solid Wastes Expected from a Large Commercial Reprocessing Plant." in Volume 1 , Management of Low-Level Radioactive Haste.

Nelson, R. G*, M* P. Schlienger, and E. V. Tiesenhausen. 1976. Selection of a Melting Furnace for Consolidation af Nuclear Fuels Hulis. BHL-1968, Pacific Northwest Laboratory, Richland, washington.

Nesbitt, J. F., and $R$. L. Treat, 1980, "Alternative Waste Forms: Process Feasibjlity." PNL-SA-8497, Pacific Northwest Laboratory, Richland, Washingtion.

Lna, $K_{*} H_{*}$, et al. 1991. Coated Particle Haste Form Development. PNL-4108, Pacific Northwest Laboratory, Richland, Washington.

Stone, J* A., S. T, Goforth, dr., and P. K. Smith. 1979. Prelimfnary Evaluation of Alternative forms for Immobilization of Savannah River Plant HighLevel Waste. DP-1545, E. I. du Pont de Nemours and Company, Inc, Aiken, South Caritina. 
4

. 


\section{APPENDIX A}

INDUCTOSLAG MELTING 
APPENDIX A

IADUC TOSLAG MELTING

\section{INTRODUCTION}

The Inductoslag melting process (Figure A.1) is basically a semicontinuous process that produces an ingat of metal using induction heating. Electric current, which is induced in the metal by a changing magnetic field, heats the metal and farms a molten melal pool. The melt is insulated from a segmented, water-cooled copper crucible by a layer of frozen slag. Melting takes place in a static one-third atmospheric pressure of helfum or argon. For the ingot mode, a pool of molten metal and siag is melted on a "starting stub, and "charged metal" and flux is fed into the top of the crucible as the ingot is extracted out the bottom. The Inductoslag process can also be used in a casting mode (Figure A,2). In this adaptation, the crucible is tilted and the molten metal is poured into a mold after the desired batch size has been melted.

Calcium fluoride is used as the flux for metais with high melting points (for example, zirconium, chromium, and titanium). Mixtures of calcium fluoride and magnesium fluoride are used as the flux for metals with lower melting temperatures for example, stainless steel, Incanel, and other ironw, nickel-, and cobalt-base alloys). Induction frequencies of 3 to $10 \mathrm{kHz}$ are required for the Inductosiag meiting process.

\section{PROCESS DESCRIPTION}

The scrap or waste metal feed materials are segregated from nommetallic material, and they are cut sa that the size and configuration of the individual pieces are compatible with the melter feed system and the size of the furnace crucible. The key component of the Inductaslag melting system is the unique segmented crucible design surrounded by an induction heating coil. The 


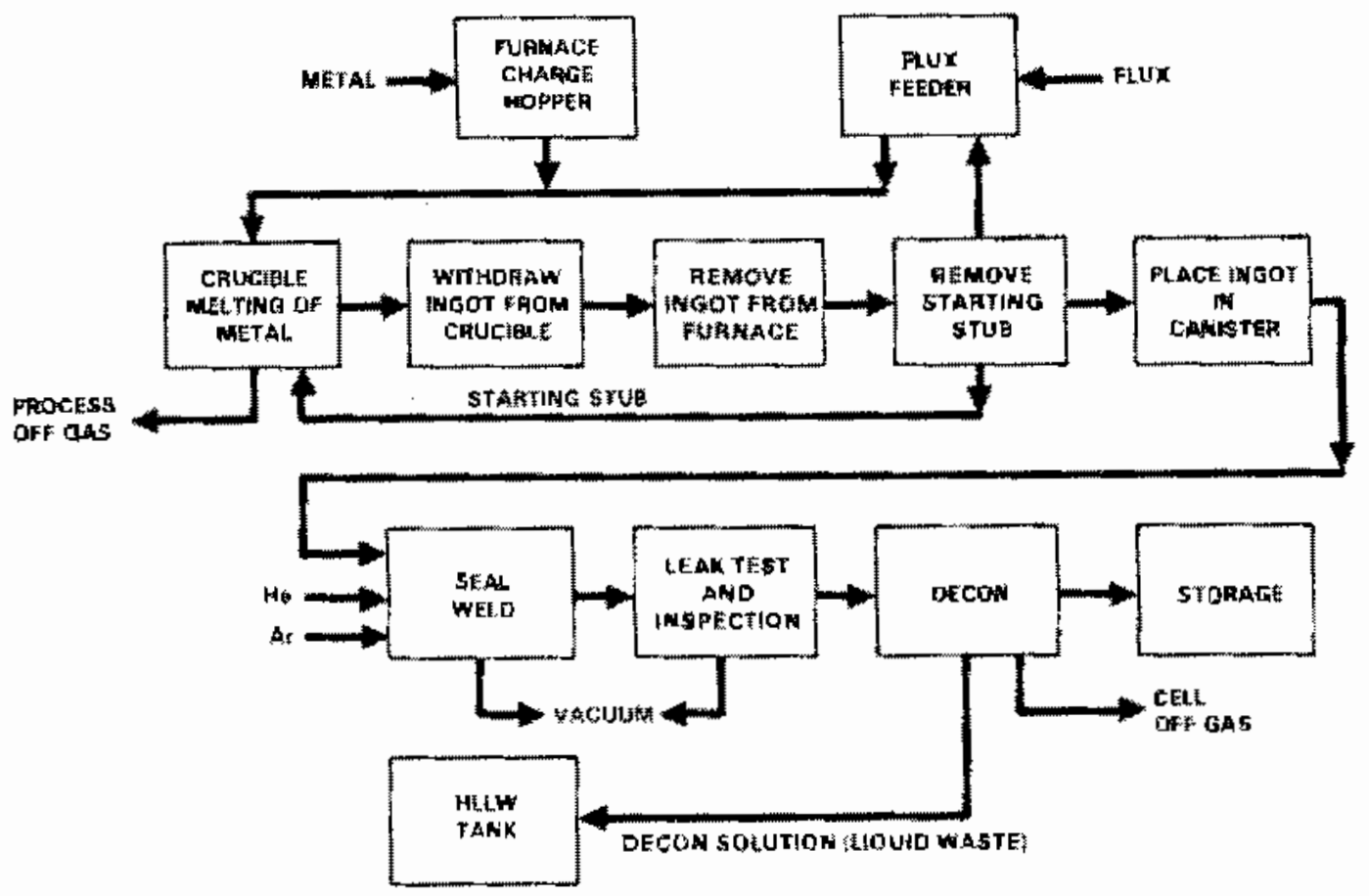

FIGURE A.1. Inductoslag Melting Process - Ingot Mode

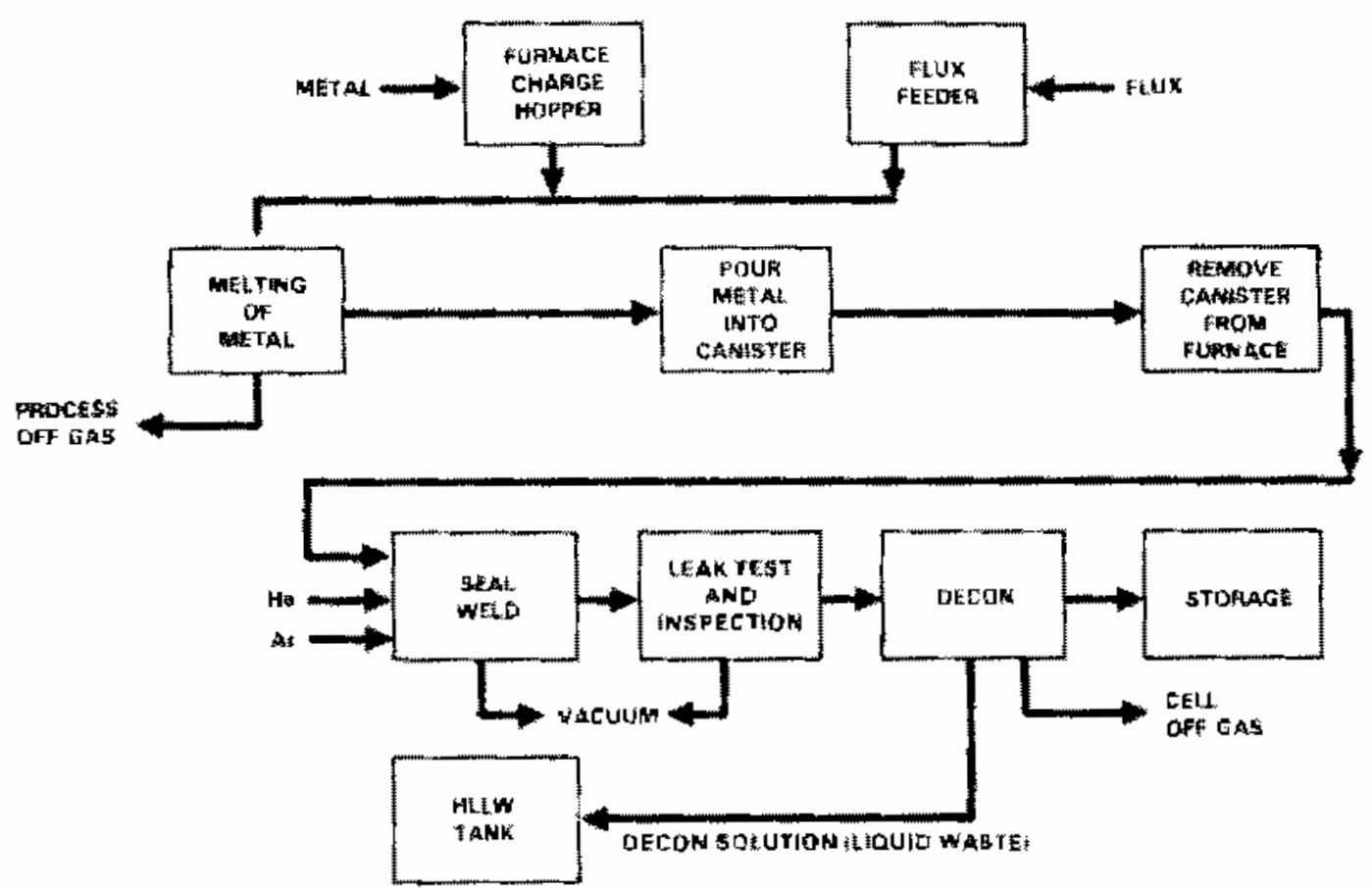

FIGURE A.2. Inductoslag Meiting Process - Casting Mode 
coaxial, water-cooled copper segments are covered by a refractory cement coating. The design and configuration of the furnace crucibles differ considerably for the ingot and casting modes.

Ingot Mode Operation

An isometric arrangement of an Inductoslag furnace and a schematic of how it produces an ingot of metal are shown in Figure A.3. A schematic of the furnace and a process flow diagram are depicted in Figure A.4 (Butcher et al. 1980). A metal starting stub(a) is positioned on the water-cooled ingot withdrawal system in the crucible, and flux $(b)$ is added to the crucible on top of the starting stub. Metallics of a known composition $(c)$ are then transferred to and charged into the furnace charge hopper, and the furnace is evacuated to $\sim 1-\mu m$ vacuum and then backfilled to $\sim 1 / 3-a t m$ argon. When the furnace power is turned on, the starting stub starts to heat and the existing flux melts by conduction. The molten flux flows down and around the annulus between the starting stub and the water-cooled crucible where it freezes and provides therma and electrical insulation. As the power is increased, part of the metal starting stub melts and forms a molten pool of metal and molten flux around the top annulus of the molten pool. Metal is fed semicontinuously into the furnace crucible from the charge hopper via a feeder system, and additional flux is fed into the furnace as required. When the volume of molten metal reaches a predetermined height in the crucible, the withdrawal mechanism is activated and the ingot is withdrawn from the bottom of the crucible and cooled. This process is continued until the desired length of ingot is attained. After the ingot is removed from the furnace, the starting stub is removed and the adhering flux can be removed from the ingot and recycled. The ingot is placed in a container with a seal-welded lid, and the loaded canister is leak checked and decontaminated as appropriate before being placed in storage.

(a) The starting stub metal should be the same as or similar to the metal being processed.

(b) The composition of the flux will vary depending on the scrap metal being charged, i.e., $\mathrm{CaF}_{2}$ for Zircaloy, $\mathrm{CaF}_{2}+\mathrm{MgF}_{2}$ for stainless steel, etc.

(c) Scrap consists of: Zircaloy hulis; stainless steel end fittings, etc.; failed equipment (mostly stainless steel); metallics separated from HLGPT (all common alloys); metallics separated from LLGPT (all common alloys); and failed equipment (all common alloys). 

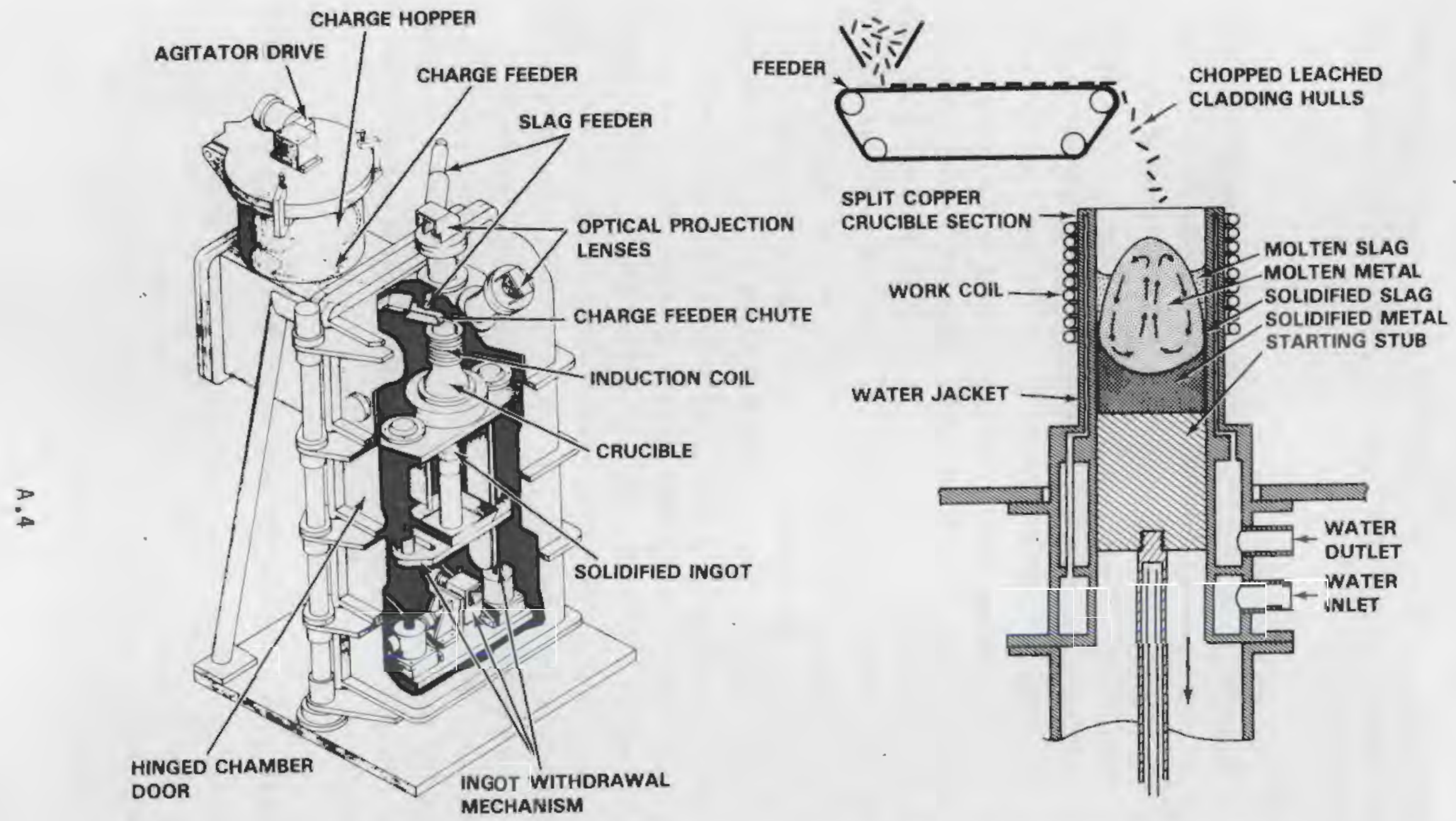

FIGURE A.3. Conceptual Illustration of Inductoslag Melting Process - Ingot Mode 


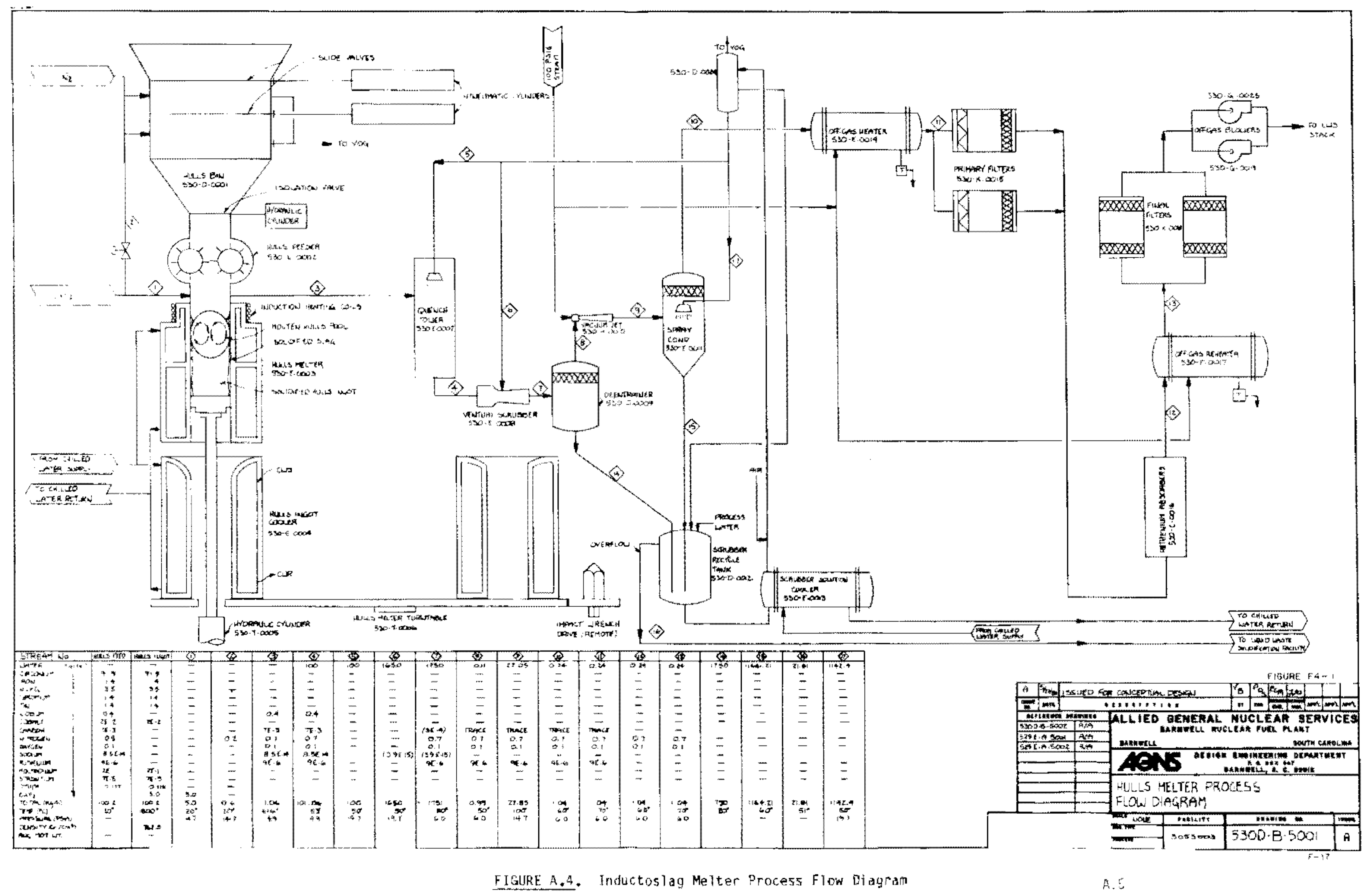



Casting Mode Operation

About one-third of the required flux charge $(a)$ is fed into the furnace and collected in the bottom of the crucible. The metal charge is fed into the furnace and crucible via the feeder system. The remaining two-thirds of the flux is then added on top of the metal charge. When the furnace power is turned on, the charge metal starts to heat and the flux melts by conduction. The molten flux forms a solidified layer between the crucible and the metal, which acts as a thermal and electrical insulator. As the power is increased, the metal charge melts. By tilting the crucible, the batch of molten metal can be poured into a mold (storage canister).

The melting and casting process is repeated until the canister is full. The filled canister is removed from the furnace and replaced by an empty canister. A lid is seal-welded on the loaded canister, and the canister is leak checked and decontaminated as appropriate before being placed in storage.

INGOT MODE PROCESS NEEDS AND REQUIREMENTS

The Inductoslag process using the ingot mode can consolidate and solidify the metallic wastes identified in the Process Material Identification section (p. 16). It will be required to produce an estimated 105 ingots $(2 \mathrm{ft}$ in diameter by $10 \mathrm{ft}$ long) or equivalent in a maximum of 300 days $/ y \mathrm{r}$, and the facility could be operated $24 \mathrm{~h} /$ day. The canisters containing the consolidated process metallics must be suitable for remote handling and transport and compatible with long-term disposal in a geologic repository. The major remote process equipment that will be required is shown in Table A.1 (Butcher et al. 1980).

\section{Furnace Feed}

The process material (hulls and miscellaneous metallic components) will be remotely handled and moved to the furnace as shown in Figure A.5 (Butcher et al. 1980). A charge hopper with the capacity to hold up to 1 day's throughput $\left(150 \mathrm{ft}^{3}\right.$ and $\left.4600 \mathrm{~kg}\right)$ will be required above and close to the furnace. It

(a) The composition of the flux is determined by the metal being melted, i.e., $\mathrm{CaF}_{2}$ for Zircaloy. The initial amount of flux required in the casting mode is $\sim 8 \mathrm{wt} \%$ of the charge metal weight; $\sim 2 \mathrm{wt} \%$ is required thereafter if the crucible skull is reused in subsequent heats. 
TABLE A.1. Major Remote Equipment for Inductoslag Melting Process

\section{Equipment}

Crane hoist

Storage crane hoist

Drum dumper crane and hoist

Drum dumper

Charge hopper

Feeder

Melter

Ingot/canister handling system

Cooler

Canister welder

Canister leak test station

Canister decontamination station

Cell cranes and manipulators

Quench tower

Venturi scrubber

De-entrainer

Steam vacuum jet

Spray condenser

Scrubber recycle tank

Scrubber solution cooler

Off-gas heater

off-gas primary filters

Ruthenium adsorbers

Off-gas reheaters

Final filters

Off-gas blowers

Scrubber solution air lift pot
Average Rate or Capacity

60 tons

10 tons

10 tons

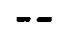

$--$
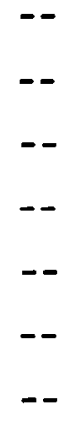

$--$

$38 \mathrm{kcal} / \mathrm{h}$

$1059 \ell / \mathrm{s}$

$22.7 \ell$

$22 \mathrm{~kg} / \mathrm{h}$

$11,400 \mathrm{kcal} / \mathrm{h}$

$1.4 \mathrm{~m}^{3}$

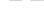

$--$
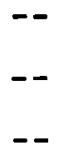

$-$ 


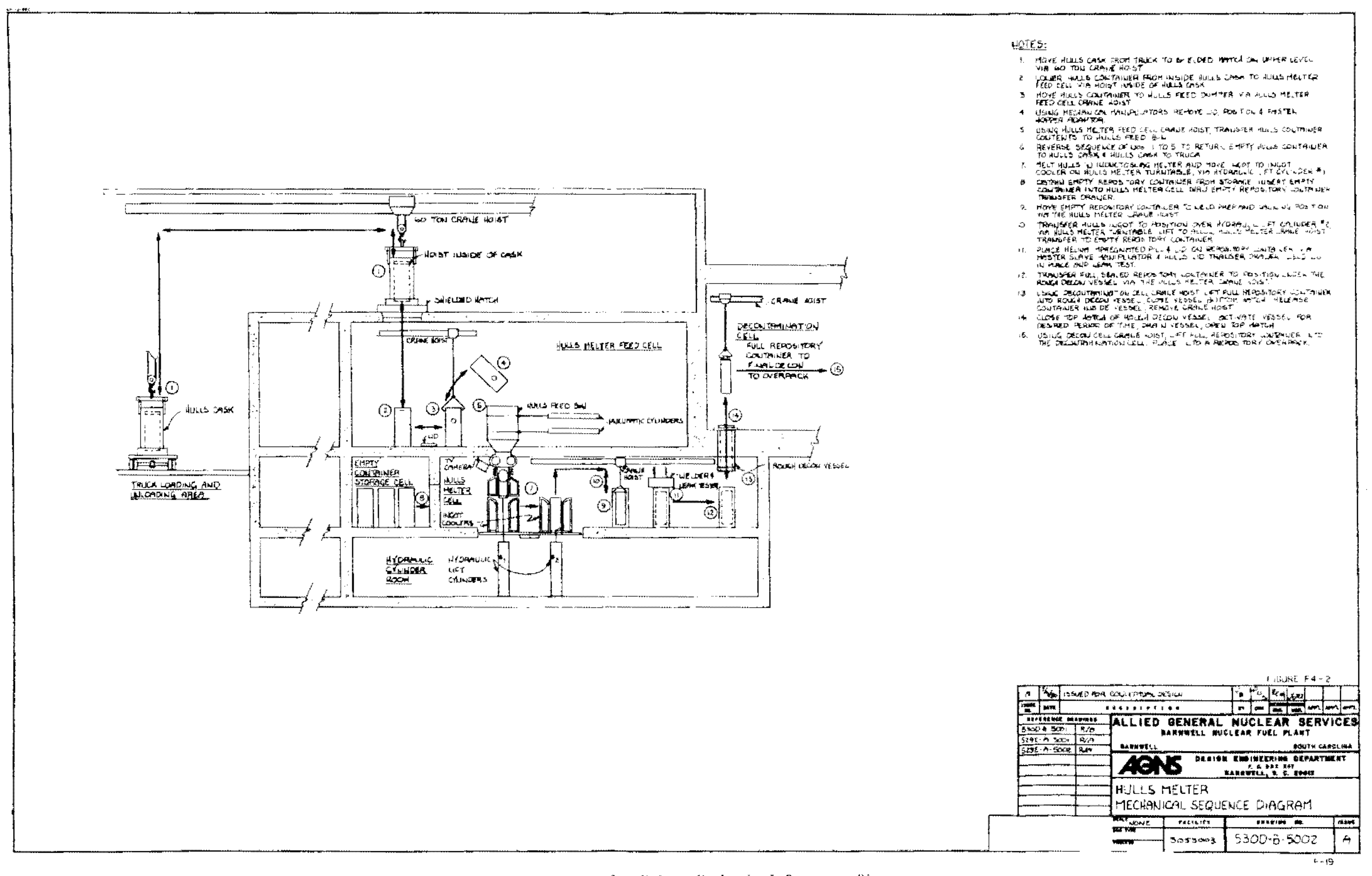



is connected to the canter cavity of the furnace with a system that will move the feed material $6 \times 6 \times 6$ in. or less) into the furnace on a demand and controlled basis without voiding the atmospheric control of the furnace.

The charge hopper and furnace feed system (figures A.3 and A.4) should be capable of feeding hulls and/or relatively small pieces of scrap metal uto the furnace crucible. Rather than reducing all of the contaminated equipment and metal to these small pieces, it may be more economical to feed them into the furnace using a separate system (a bucket charge system). A secand feed system could be incarporated into the design and operation of an Inductoslag ingot mode furnace

The flux feed system is attached to the upper portion of the furnace. It introduces the required fuxes into the core of the furnace on a controlled and demand basis. Flux is supplied and fed from a series of hoppers that hold at least a 7-day supply of the required fluxes.

\section{Furnace}

An Inductoslag furnace simatar to the ones shown in Figures A.3 or A.4 will be required. To produce an ingot $10 \mathrm{ft}$ long and $1 \mathrm{ft}$ in diameter (which is felt to be the maximurn possible dameter) will require a furnace that is $* 6 \times 12 \times 20 \mathrm{ft}$ bigh. After the desired length ingot is produced, it can be withdrawn entirely from the crucible via the ingot withdrawal mechanism. The supported ingot can be ratated or moved ta a postion for transfer to an external station. After a new starting stub is inserted into the furnace, it. is ready to melt and form another ingot.

Based on an engineering study, it has been assumed that it is feasible to make an ingat $1 \mathrm{ft}$ in diameter by $10 \mathrm{ft}$ long in a furnaca cycle time of $-8 \mathrm{~h}$ (with a maximum instantaneaus nelt of $\times 150 \mathrm{~kg}$ ). Thus, one inductoslag furnace could produce three such ingots in $24 \mathrm{~h}$, and it could process the estimated annual facility throughput in 157 days. About 464 ingots weighing an average of $1390 \mathrm{~kg}$ and canisters filled to $90 \%$ capacity would be produced. The 1-ft by 10mt ingot will require handing and processing about four times more canisters than 2-ft diameter by 10 - ft long ingots. 
Ingot Transport and Encapsulation

The mechanical sequence diagram in Figure A.5 shows the steps and a tentative arrangement of an Inductoslag ingot melter and its material handling system. This system does not include the option of removing the starting stub from the ingot. However, the stub would not have to be removed if 1 ) it is made of pracess material in a separate step in the hot cells or 2) the reduced efficiency of a canister containing a starting stub made of nonprocess material is acceptable. Otherwise, an additional station to remove the starting stub from the ingot would be required between the melter and the canning station. If included, more space would be required and the equipment would have to be rearranged.

After the ingot is inserted into a canister, a lid is sealwelded in place by a remote welder. (a) The canister is then checked for leaks. Either of two leak detection systems that have been used in remotely operated, radioactive processes can be utilized: helium detection or ultrasonic examination. Fol lowing leak detection, the canister can be decontaminated if required; or decontamination may be performed just prior to maving the canister from the process cell.

Although the welding and leak test stations are combined in Figure A.5, they could be separate. Combining stations reduces the number of times an ingot or canister must be moved and the size of the required processing facility. However, concentrating relatively complex or remotely operated equipment in a small area may be undesirable.

\section{CASTING MODE PRDCESS NEEQS AND REQUIREMENTS}

The Inductoslag process using the casting made will cansolidate and solidify the metallic wastes identified in the Process Material Identification section (p. 15). It will be required to produce an estimated 116 fuel canisters (2 ft in diameter by $10 \mathrm{ft}$ long and $90 \%$ full) or equivalent in 300 days or less, and the facility could be operated $24 \mathrm{~h} /$ day. The canisters containing

(a) Such welder has been developed and demonstrated at Pacific Northwest Laboratory (PNL) (Treat et al. 1980). 
the consolidated process metallics must be suitable for remote handling and transport and compatible with long-term disposal in a geologic repository. The major remote equipment that will be required is listed in Table A.l.

Furnace Feed

Provisions to introduce the process material to the furnace charge hopper could be the same as those jdentified for the ingot mode. A charge hopper with the capacity to hold up to 1 day's throughput $\left(150 \mathrm{ft}^{3}\right.$ and $\left.4600 \mathrm{~kg}\right)$ will be required above and close to the furnace. It is connected to the center cavity of the furnace with a system that will move the feed material $(6 \times 6 \times 6$ in. or less) into the furnace on a fast-feed and controlled basis without voiding the atmospheric control of the furnace.

For this process, an alternative to reducing all metallics to small pieces ar requiring a second furnace charge system would be to load a predetermined amount of large scrap pieces into the bottom of an empty canister prior to its insertion into the furnace. This material would be cavered and essentially surrounded with molten metal from subsequent batch pours,

The flux feed systen is attached to the upper portion of the furnace. It introduces the required fluxes into the core of the furnace on a controlled and fast-feed basis. Flux is supplied and fed from a series of hoppers that hold at least a 7 may supply of the required fluxes.

\section{Furnace}

An Inductoslag furnace similar to the one shown in Figure A.6 will be required. To produce a casting in a canister $10 \mathrm{ft}$ long by $2 \mathrm{ft}$ in diameter will require a furnace that is $-6 \times 12 \times 24 \mathrm{ft}$ high. Based on an engineering study, it has been projected that it wald be feasible to fill a 2 -ft diameter by $10 \mathrm{mt}$ long canister $906 \mathrm{full}$ in a furnace cycle time of $-66 \mathrm{~h}$. This could be done by batch melting and pouring 55 melts of $-100 \mathrm{~kg}$ each. The maximum molten metal in the crucible at one time would be $\times 150 \mathrm{~kg}$; thus, 116 canisters could be produced in 321 days. Two furnaces would be required to process the projected facility throughput within the 300 working days. 


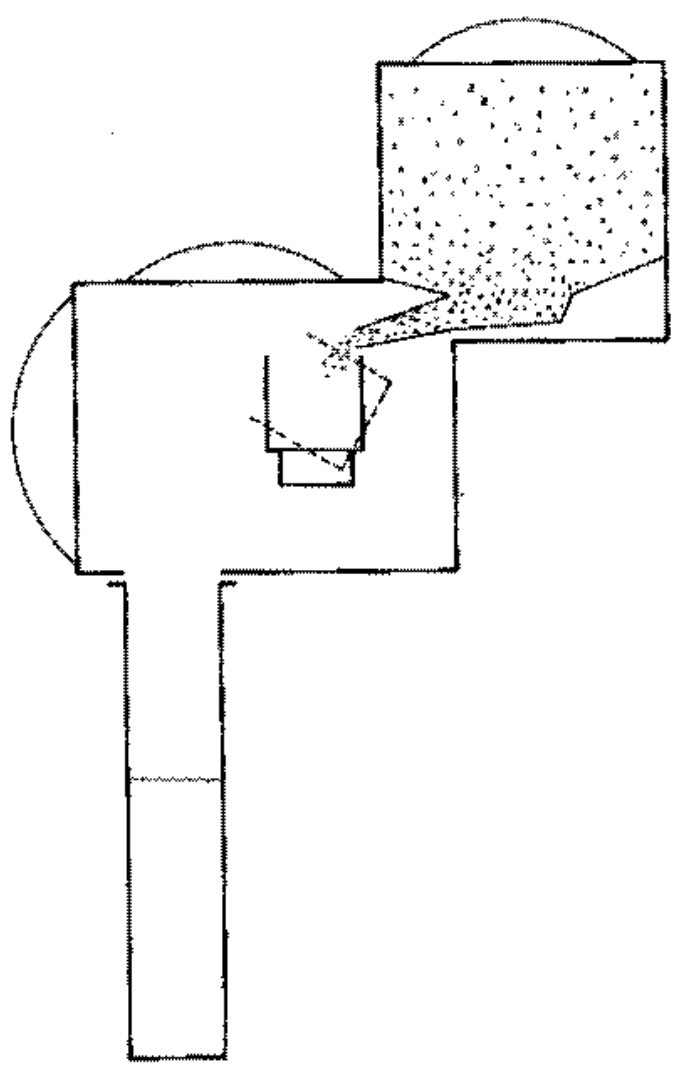

FIGURE A.6. Conceptual Arpangement of Inductoslag Melt-and-Pour Furnace

\section{Canister Handling and Transport}

The system required to handle and transport the 6-to 7 -ton canister will be similar to but somewhat less complicated than that required for smaller ingots and canisters. The canister handling system must be able to:

- bring an empty or partially filled canister to the furnace

- insert the empty or partially filled canister in the furnace

- remove the full canister from the furnace and contain it in a cooling station

- move the canister from the cooling station to the closure station

- move the closed canister to the leak detection station

- move the closed canister to the decontamination station if required 
- move the decontaminated canister to storage or to the out-of-cell transfer station.

The canister cooling, closure, leak test, decontamination, and storage stations are all similar or identical to those stations identified for the ingot process.

\section{FACILITY REDUIREMENTS}

The overall requirements for a waste facility are generally similar for all the consolidation processes. Preliminary layouts of an Inductoslag furnace (ingot mode) without a starting stub removal station are shown in Figures $A .5$, A.7, and A.8 (Butcher et al, 1980). The overall facility requirements for the casting mode would be simflar to but larger than those far the ingot mode if a second furnace is required to meet throughput needs. The canister handing steps would also be rearranged for the casting mode.

\section{off-Gas System}

The off-gas system cools the gases generated during the melting operation and pilters out any particulates or volatile fission products that may come from the furnace system. As identified by Andersan, Carr, and Mitche11 (1982), the gas from the melter passes through a quench tower to remove process heat and to condense water vapor and then moves to a venturi scrubber for particulate removal. off gas from the venturi scrubber passes through a de-entrainer and a vacuum jet into a spray condenser. The off gas, which consists primarily of nancondensable gases and residual particulates, is then heated and passed through a prefilter, a single high-efficiency particulate air (HEPA) filter, a ruthenium absorber bed, a reheater, and two stages of HEPA filters in series. The off gas is then exhausted into the waste processing center (WPC) gaseous effluent system or through blowers and out a stack. A flow diagram of the of $f$ gas system is shown in Figure $A .4$ and its throughput is summarized below: 


$\begin{array}{ll}\frac{\text { Effluent }}{\text { Gases(a) }} & \frac{\text { Flow Rate }}{30 \mathrm{~m}^{3} / \mathrm{min}} \\ \text { Particulates (b) } & 4.0 \mathrm{~kg} / \mathrm{h}\end{array}$

(a) From furnace at $600^{\circ} \mathrm{C}$ and $1 / 3$ atm.

(b) Metal fumes contaminated with radiolsotopes.

Secondary Hastes Requiring Processing

Nonradioactive solid and liquid wastes will be handled in supporting systems. Wastes that will require processing for either of the inductosiag melting furnace processes are listed below:

\begin{tabular}{|c|c|}
\hline Material & Amount \\
\hline Nonradioactive cooling water & $1000 \mathrm{R} / \mathrm{min}$ \\
\hline Process wastes & $10 \mathrm{~kg} / \mathrm{h}$ \\
\hline Ventilation flow & $500 \mathrm{~m}^{3} / \mathrm{m}^{2} \mathrm{n}$ \\
\hline
\end{tabular}

Utilities, Services, and Materidis

Estimates of the normally required utilities, services, and materials that will be needed for either of the Inductoslag melting processes are sumnarized in Table A*?.

TABLE A.2. Utilities, Seprices, and Materials for Inductoslag Melting Praces 5

\begin{tabular}{|c|c|c|c|}
\hline Item & Capacity & Average Rate & Amount/Year \\
\hline $\begin{array}{l}\text { Electricity } \\
\text { Water } \\
\text { Air } \\
\text { Stean } \\
\text { Flux }\end{array}$ & $\begin{array}{l}1200 \mathrm{~kW}, 3 \mathrm{kHz} \\
1800 \mathrm{kmin} \\
750 \mathrm{~m} / \mathrm{min} \\
15 \mathrm{~kg} / \mathrm{min}\end{array}$ & $\begin{array}{l}900 \mathrm{kH} \\
1200 \mathrm{~g} / \mathrm{smin} \\
500 \mathrm{~m}^{3 / \mathrm{min}} \\
2 \mathrm{~kg} / \mathrm{min}\end{array}$ & $\begin{array}{l}6,500 \mathrm{~kg} \\
13,000 \mathrm{~kg}\end{array}$ \\
\hline Canisters & $\begin{array}{l}1 \mathrm{ft} \text { did } \times 10 \mathrm{ft} \text { long } \\
2 \mathrm{ft} \text { dia } \times 10 \mathrm{ft} \text { long }\end{array}$ & & $\begin{array}{l}470 \text { each } \\
120 \text { each }\end{array}$ \\
\hline He sources & & & 500 or 150 each \\
\hline Argor & & & $\begin{array}{l}2300 \mathrm{~m}^{3} \text { (ingot) } \\
600 \mathrm{~m}^{3} \text { (cast) }\end{array}$ \\
\hline
\end{tabular}

A. 16 


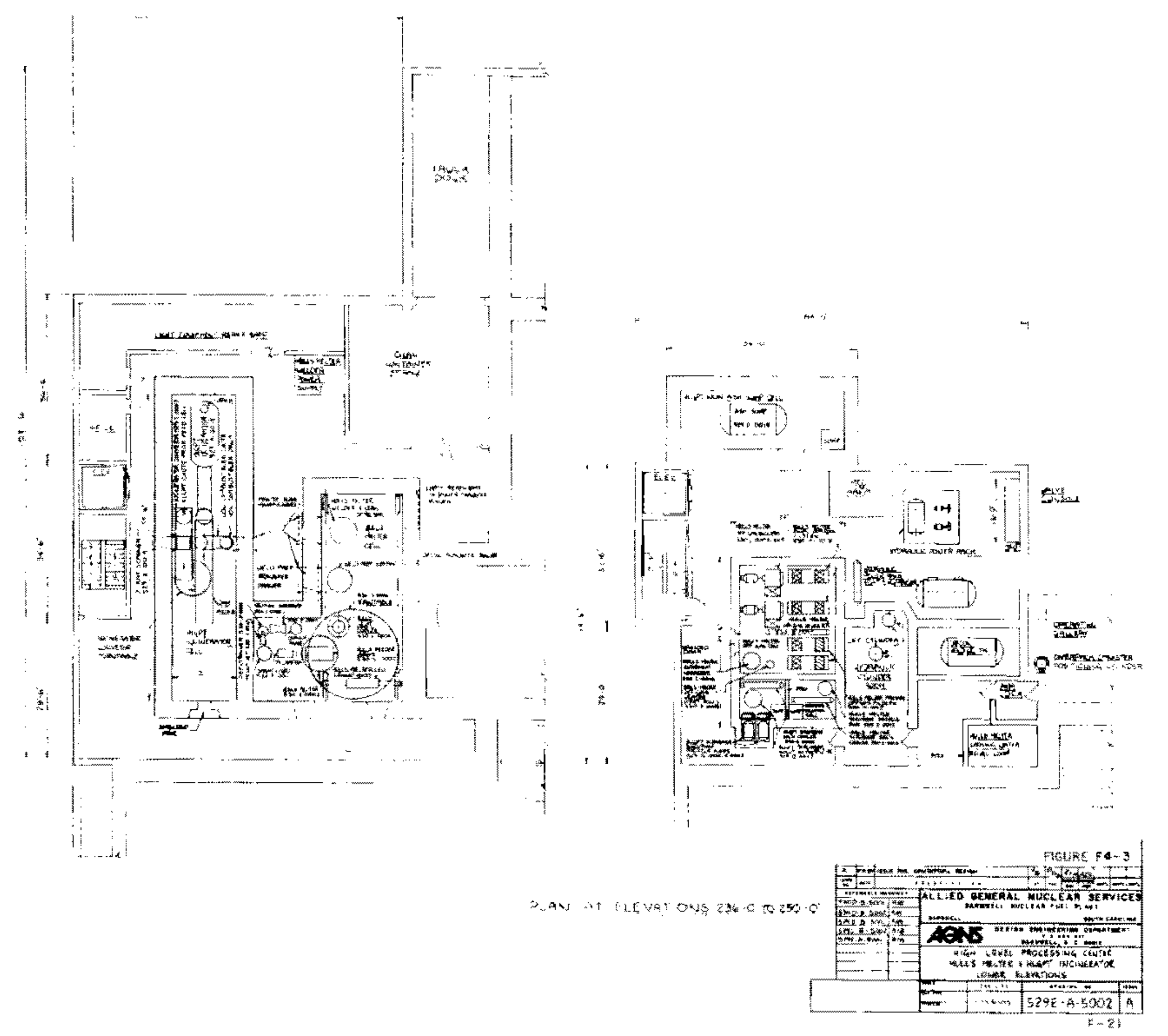

FIGURE A.7. Lower Elevations of Preliminary Layout for Inductoslag Furnace System 



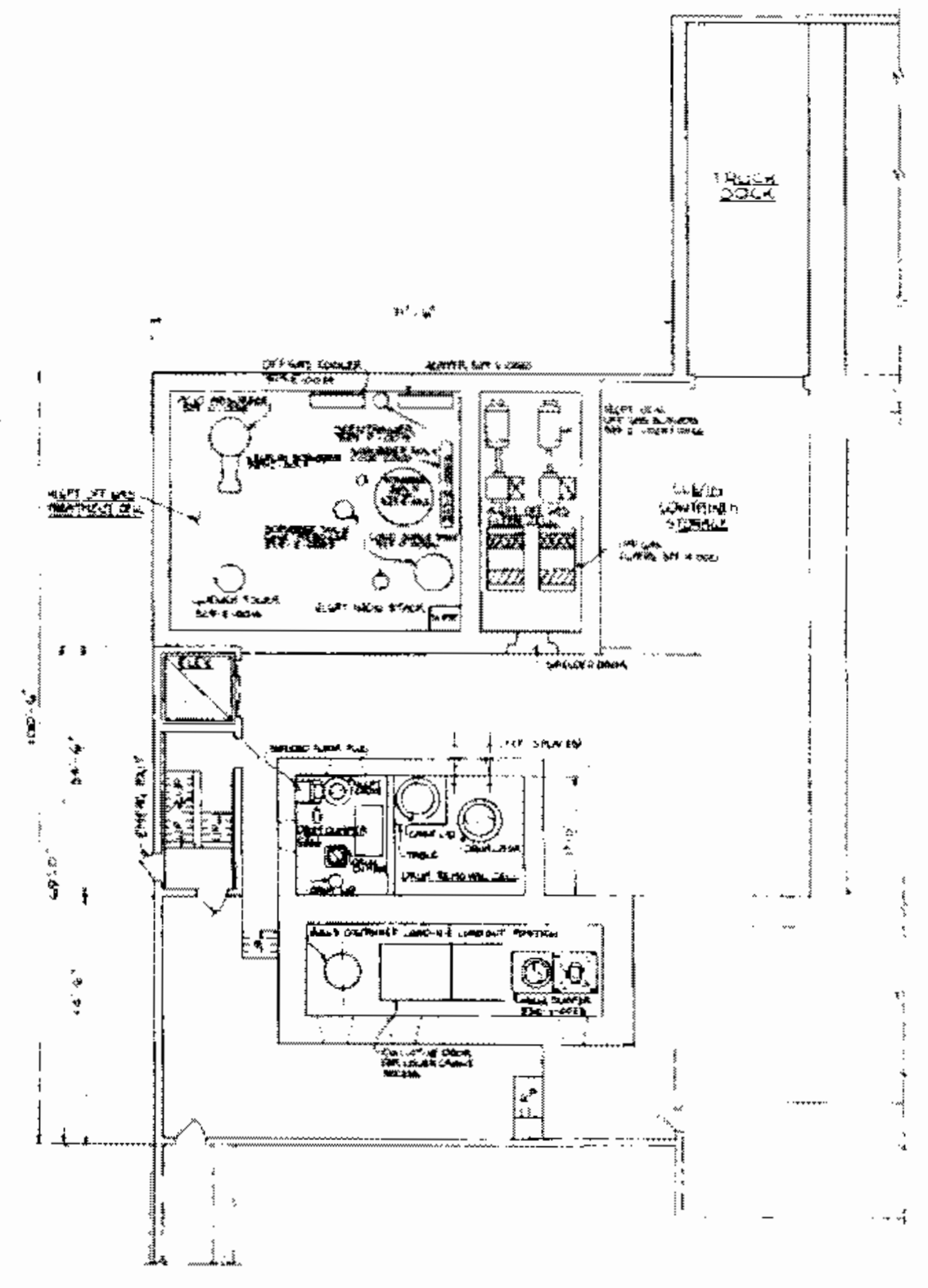

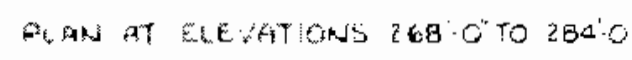

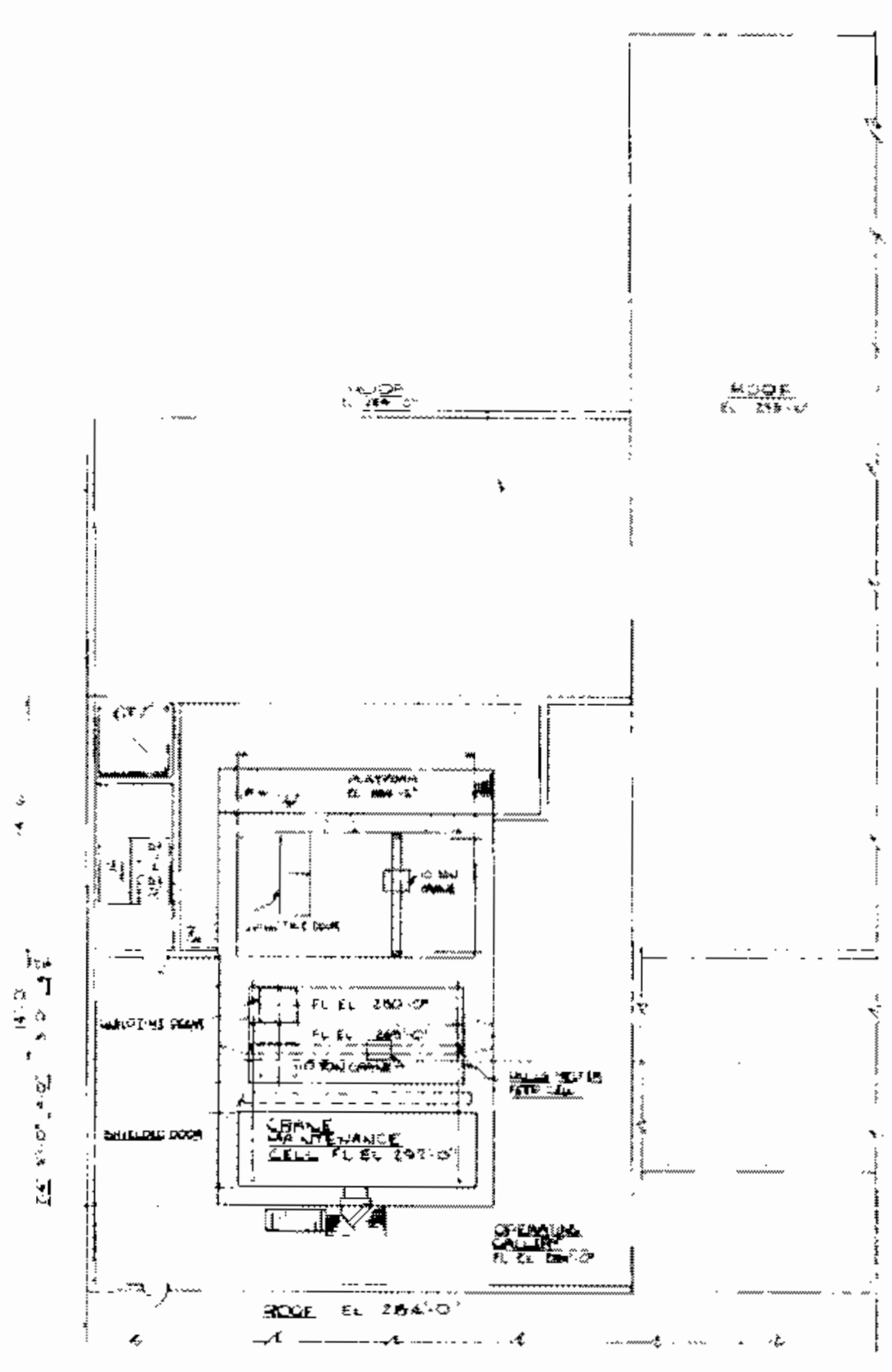

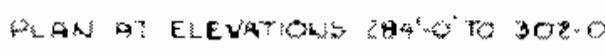

PGSARE FA-4

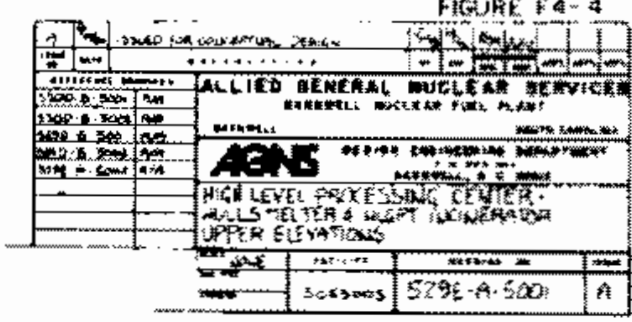

EIGURE A.B. Upper Elevations of Preliminary Layout for Inductoslag Furnace systen 



\section{ASSESSMENT DISCUSSIDN}

Inductoslag - Ingot Mode (Reference Process)

Based on the present state of the art of the Inductoslag furnace and its made of operation, it has been assumed that the maximum crucible diameter will be $-1 \mathrm{ft}$. This limitation directly and indirectly impacts the feasibility of using this process to consolidate metallic wastes. It adds to the complexity of the process, and a larger number of small canisters would be produced. Because the subsequent costs for transportation and geological storage are based primarily on the number of units, these costs could be up to four times greater than those for canisters from another process. The numerical ratings assigned to the Inductoslag ingot mode process by the individual evaluators are shown in Tables A.3, A.4, and A.5 (see p. A.32). The criteria are discussed below.

\section{Complexity of Process}

The to the projected limitation on crucible and ingot diameter ( $1 \mathrm{ft})$, the Inductoslag process involves more process steps and the handling of more canisters than the other processes. The separation and recycling of starting stubs and fluxes also complicate the process, The equipment required, its complexity, reliability, and maintenance considerations are considered to be better than normal for a remote process of this type. Remote operation and maintenance of this equipment, however, will not be without some problems.

Process controls are viewed as state of the art, and most have a reasonable allowable operating range. Na special problems are anticipated in adapting this protess to remote operation, and the crucible diameter is the anly limiting factor for larger scale production use. 
Material Handing. The initial material handling consists of transporting the feed materials to the WPC in shielded and sealed containers. Individual containers mst be removed from the casks and put into process cells for storage or Introduction into the consolidation process. This portion of the material handling is assumed to be essentially identical or at least very similar for a 11 consolidation processes.

For this process, the individual contafners are opened remotely and the process material is dumped into the process feed hopper. The material is then automatically fed into the furnace on a demand basis. A starting stub must be remotely inserted and positioned in the furnace, but the ingot will be withdrawn automatically. Remote aperational in-mell equipment will also be required to cool the ingot so that it can be removed from the furnace. It may also be necessary to remove the starting stub and the adhering flux. Remote equipment will also be necessary to insert the ingot into a canister.

Other remote equipment will be required to seal, leak test, decontaminate, and transport the canister. This equipment will be identical or at least very similar for all consolidation processes. The remote recycling of starting stubs and flux material is anticipated.

Consolidation Mode. The Inductoslag melting process will be performed in a contralled atmosphere and pressure, and it will require water cooling. Mechanisms will be required for the controlled feeding of the process matertal and fluxes and the controlled withdrawal of the ingot whlle maintaining the requitred atmosphere.

Maintenance Considerations and Equipment Rellability. The interior of the furnace will be designed for decontamination by washdown, vacuuming, or similar methods. The coil and crucible assembly and mechantsms for ingot withdrawal, metal feed, and flux feed will all be replaceable as modules. The overall reliabllity of this melting system is relatively high with the weakest point being the segmented crucible. If a heavy piece of feed metal struck the seg mented side wall of the crucible, it could knock the crucible but of allgnment and allow molten metal to rum out past the solidified portion of the ingot and into the area below. A heavy sharp piece of metal feed could puncture ane or 
more segnents and cause a water leak. The interior of the furnace will be accessible for checking, cleaning; and removing modules.

Remotely operated in-cell equipment will be required to maintain and replace process equipment (cranes, manipulators, and robotics). Provisions must also be made for the mantenance and/or removal of the crane maintenance roor, shifelded areas, out-of-cell cranes, and cell cover blocks. Special tools, adapters, jigs, and flutures wll be required in the hot cell for main tenance and replacement activities; and extra cell space must be provided. Visual access to all areas in the cells is important; viewing windows, periscopes, and clased circuit telerision will be provided.

Controls and Cperation. The controls for this furnace and its operation are complex but straightforward. Once melting is initiated, the power setting to the coll requires very little montoring. The metal feed control allows the operator maximum flexibility in the amount of material in the crucible at any given time. The flux feeder operates the same as the charge feeder. Withdrawal of the ingot is easy although it must be coordinated with metal feed rates and melting times and temperatures.

The operational steps and controts required to supply the feed materials to the furnace and to handle the ingots and the canisters produced are all essentially batch-iype operations. Each will require statemof themart controls whose sequence and timing will have to be coordinated.

Adaptability to Remote Geration. A laboratory-scale Inductoslag furnace with a 4-in. diameter crucible was operated remotely during $\rightarrow 60$ heats at PNL. Internal operations were viewed on monitors on the console, which was $15 \mathrm{ft}$ from the furnace. A11 feeding and ingot withdrawal was aiso remotely operated from the console. Although this furnace was designed for use in a semihot cell, it has only been operated in the laboratory; and no remote thaintenance or replacement activities have been required or performed. With adequate design and testing time, no special problems are anticipated for a production-size furnace in a fully remote operational mode, All other remotely operated equipment (with the exception of radiation-resistant and decontaninable robotic devices) will be simlar to adaptations of current applications. 
Number of Process 5teps. From the time the metal is loaded into the charge hopper until a canister is filled, at least 11 individual process steps whl be required. Initial and final steps are batch-type operations, but the melting of the process material is essentially a continuous process.

Feasibility for production. All steps in the fnternal operation of the Inductoslag furnace have been performed from remote consoles; thus, they are viable for production. The time required to remave and process a number af ingots remotely would appear to be compatiole with the furnace cycle times. The ingot/canister processing steps that are not automatically sequenced and that require the operation and sequencing of a variecy of remote mechanical equipment could be the limiting throughput factor. However, all are feasible for application in a remote production facillty.

Feed Limitations. The diameter and size of the crucible along with the ability of the feed mechanisms to handle a range of sizes will set the maximum dimensions and weight of the feed material. A maximum individual size of $6 x$ $6 \times 6$ in* and a weight of 60 is have been assumed for this pracess. However, if there are any pieces of feed material that weigh more than 4 or 5 lo or are much larger in any dimension than the fuel hulis, their entry into the crucible or molten batch of metal will have to be controlled. Thus, a second feed system will be required. These larger itens, which constitute $-13 \%$ of the annual plant throughput, could be fed into the furnace using charge buckets.

\section{State and Type of Development}

Experimental and developmental wark on Inductoslag furnaces for use in nuclear applications has been ongoing since 1975. Considerable laboratory * scale and cold pilot-scale work and process runs have been made; bastic operating parameters, modes, and controls are well defined, Operating parameters and supporting system requirements for a $3 x$ scale-up need to be determined, and the remote operation and maintenance of a production-scale furnace needs to be demonstrated.

Process and/or Equipnent. From 1975 to the present, Inductoslag ingot furnace developments have included: 
- development of the melting process and equipment by the $U_{*} S_{*}$ Bureau of Mines (USBM) at Albany, Oregon

- evaluation of Inductaslag melting by PNL for consolidation of Zircaloy hulls at the USBM, Albany, Oregon

- design and fabricacion of prototype furnace for PNL by Retech, Inc., Ukiah, California

- prototype furnace delivered in 1977 and installed in 1978

- hands-on furnace operation from 1978 to the present; 60 heats have been conducted including -30 heats of zircalay cladding, 10 of stainless steel, and 20 of titanium alloys; two segments of the crucible have been replaced and it has been realigned once

- valuable design and operating information has been gained that is applicable to future destgns or remote applications. Type and Scale of Development. Developments that will be required priar to actual hot cell operation of an Inductosiag furnace include:

- investigate the capability of Inductoslag melting on a variety of metals

- determine off-gas temperatures and the system to adequately process the contaminated of gases and particulates

- develop and test remote cleaning of sight glasses

- develop and demonstrate the capability of the system to clean the inside of the furnace remotely

- demonstrate remote operation and reliability of large-scale Inductoslag furnace

- identify means to remove and replace the furnace and camponents remotely

- demanstrate the remote handing of ingo:s and containers. Development Time Required. The required design, fabrication, and testing could be done in a period of 24 months. 
Safety

Two primary hazards are associated with the Inductosiag melting system in addition to the normal concerns regarding the processing of radioactive material:

- A water leak in the crucible during the melting of zirconium could result in a steam expansion and a simultaneous reaction of the molten metal and water, foming hydrogen. Explosive mixtures of hydrogen and air could be released to the surrounding area or CEll.

- Finely divided metallic residues that deposit on interior melt chamber surfaces during normal melting (especially zirconium) are a potential fire hazard when the furnace chamber is opened or air is introduced.

other potential hazards (crucible failure, spills, etc.) are common to conventional melting of metals. Although the molten metal in this furnace can be up to $1900^{\circ} \mathrm{C}$, its volume is relatively 5 mall $(155 \mathrm{~kg})$. If a water leak ever developed in the crucible, the chances of water being trapped under the moiten metal are not very likely due to the size and open bottom design of the crucible.

Since all radioactive material will be processed in shielded hot cells and devices designed for that purpose, the amount of excess radiation exposure will be a function of equipment maintenance and replacement, process accidents, or equipment failures.

\section{Process Requirements}

Less process off gases that require treatment will be generated for this melting process than for most others; however, it will require the addition of flux material and a greater number of canisters than the other processes. Althaugh a wide mixture of metals can be safely melted, different metals and nonmetallics will have to be controlled to assure the structural and handing integrity of the ingot. Unless it is possible to use larger diameter crucibles to make bigger ingots, the production capacity of this furnace concept is limited. 
Secondary Wastes and Off Gases. As with any melting system, this process will produce off gases that will require treatment. Residue consisting of condensed metallics, slag, and flux will be deposited on the furnace interior. These and other miscellaneous wastes, cooling water, and process cell ventilation air will require handing and/or treatment.

Production Capacity. Based on the present state of the art, the Inductoslag ingot mode of operation is limited to m l-ft diameter ingots. The throughput capacity of a furnace is limited by this factor as well as other more typical factors such as melting rate, avallable space, and required material handling steps.

Process Additives and Auxilliary Materials/Utilities. This process requires the addition of flux chemicals patterned to the metals to be melted (4 wty). The power and cooling required per unit of metal throughput are averm age for melting processes. Gas addition and atmospheric control volumes are about the same as for most melting processes.

Process Versatility and control. This process will melt a wide variety of metals and, within the linits imposed by the off-gas system, some combustible and nonmetallic materials. The type and amounts of these nonmetallit feed materials would be limited by the need to assure the integrity of the ingot. until it could be placed in a canister. To be certain that an ingot is in one plece and suitable for loading into a canister will be a definite qualty control checkpoint for this process.

Manpower. Furnace operations are primarlly automated and will not require as many personnel as required for the material handling operations to feed the furnace and process the ingots.

\section{Facility Requirements}

The facility required to house and support this Inductoslag furnace will be a typical one for highly radioactive processes where both chemical and mechanical processes are involved at multilevels in the building. Thus, it will be considered as the reference facility for evaluation purposes. 
Inductoslag - Casting Mode

The assumed 1-ft crucible diameter limit adversely impacts the costeffective use of this process for this application, It adds to the equipment required and to the cost of operation. The numerical ratings assigned to the Inductoslag casting mode process by the individual evaluators are shown in Tables A.6 through A.9 (see P. A.35). The criteria are discussed below.

\section{Complexity of Process}

The projected crucibie diameter puts a severe limit on batch size that results in a high number of process steps and requires more time. To meet time constraints, two furnaçes would be required, which will add to the complexity of the feed and canister handing systems. Remote operation and maintenance of the required equipment can be expected to provide some problems. Process con trols are straightforward, and no special problens are expected if this process is applied remotely.

Material Harding. The steps and processes required to bring the process materials into the facility and feed them into the furnace are the same as those identified for the reference process. Less in-cell handing equipment will be required than for the reference process because there are no starting stubs to be separaced from the ingot and recycled nor is there any flux to be removed from the ingot and recycled. The canister is loaded in the furnace and there are no ingots to be moved or transported outside a canister. About onefourth as many canisters will need to be handled and transported as campared with the reference process.

Cansolidation Mode. Batches of molten metal are poured into a canister in the furnace. Otherwise, the consolidation mode is the same as for the reference process.

Maintenance Considerations and Equipment Reliability. The equipment for this melting system is somewhat more reliable than the equipment for the reference system because its furnace crucible is not as vulnerable. The tilt-andpour mechanism is somewhat less complicated and more rellable than the ingot withdrawal system. since there is no need for equipanent to separate the 
starting stub, remove the slag or flux from the ingot, recycle the fluxes and starting stubs, and handle ingots, there will be fewer naintenance requirements than for the reference process.

Controls and Operation. The controls and operation will be very simflar to those for the reference process. More batch operations will be required per canister in the furnace, but no ingots and fewer canisters will be produced that require handling.

Adaptability to Remote Deperation. Based on experience with laboratoryscale Inductoslag furnaces and consideration of the required process steps and equipment, it is felt that the casting mode of operation would be more applicable to remote pperation than the reference ingot process.

Number of Process Steps. Approximately 60 individual furnace steps (mostly short-term batch operations) will be required to fill one large canister after the feed material is loaded in the hoppers. However, 64 steps are required to fill and complete the processing of one canister-uthe same as that required to process an equal amount of material in the reference process (four l-ft diameter canisters).

Feasibllity for Production. As with the reference process, all phases of the Inductoslag furnace are considered viable for production. However, due to the time required to fill a canister witb small batch pours, the furnace capacity will no doubt be the determining throughput factor; and two furnaces may be required to meet production demands.

Feed Limitations. As with the reference process, material larger or heavier than the hulls can only be introduced into the crucible or molten metal pool by clasely controlled means. However, rather than a second feed system for this furnace, the larger and heavier pieces of material could be placed in an empty canister prior to its insertion into the furnace. Processing 13 of the facilities throughput in this manner should reduce the overall process requirements of time, power, etc., without any additional complexity.

State and Type of Development

Process andior Equipment. The state of the development for the casting Inductoslag furnace is the same as for the ingot Inductoslag furnace. 
Type and Scale of Development and Time Required. These thems are the same as those of the reference process.

Safety

Potential process upsets or considerations that may create safety hazards are the same for this process as for the reference process.

process Reguirements

This mode of operation will require more flux but fewer canisters than the reference process. It has more latitude on process feed materials because the material is cast into a canister. The need for two furnaces to process the required throughput complicates the material handling equipment requirements. If larger diameter crucibles (up to 2-ft diameter) are found to be feastbie, a onemurnace operation would provide extra capacity.

Secondary Wastes and Off Gases. Constituents and annual amounts generated will be the same as for the reference process.

Production Capacity. As with the reference process, a l-ft diameter crucible is considered maximum; the maximum depth of the cructble is $\sim 1.5$ times the diameter. These factors limit the capacity and the throughput of an Inductoslag furnace, and two furnaces will be required to meet the projected throughputs and rates.

Process Additives and Auxlliary Materials/Utilities. This process will require about two times more flux feed than the reference process because nane of the flux is recycled. Fewer canisters, helium sources, weld material, and about one-third the argon gas will be needed; otherwise, process needs are the 5 ane as for the reference process.

Process Versatility and control. Like the reference process, this process will handle and melt a wide range of metals and mixtures. Hecause this mate* rial is cast inside a canister, a wider range of metal mixes, batches, and foreign materials could be procassed without imposing a potential quality control problem of ingot or casting integrity. 
Manpower. Due to a longer furnace cycle than the reference process, two furnaces will be required and the process will be run about the same number of days/year as the reference process (160 yersus 157 days).

\section{Facility Requirements}

The facility required to enclose and support this process with two furnaces will be larger than that identified for the reference process or facil$i$ ty, It is estimated that the required hot cell space would be 1.25 times larger and the supporting factlities would be 1.1 times larger than those of the reference process. Installation would also be more complex than that of the reference process because of the two furnaces and their process feed and removal system requirements.

\section{REFERENCES}

Anderson, K. J., W. H. Carr, and R. C. Mitche1l, 1982. BNFP Waste Characterization and Waste Treatment. PNL-3136/FR-01, Allied-General Nuclear Services, Barnwell, South Carolína.

Butcher, J. R., et al. 1980. Studies and Research Concerning BNFP: Engineering Evaluat ons of Wastes HandTing and Storage Facilities. AGNS35900-4.2-26, Altied-General Nuclear Services, Barnwelt, South Carolina.

Treat, R. L., et al. 1980. Preliminary Evaluation of Alt ernative Waste Form

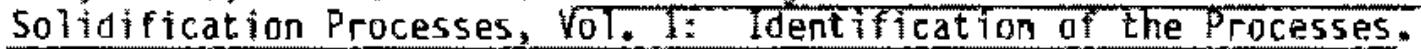
PNL-3244, Pacific Northwest Labaratory, Richland, Kashingtan. 
TABLE A,3. Inductoslag Ingot ode System Evaluation - Evaluator A

Complexity of Process

Matertal Handiong

Consolidation Mode

Maintenance Considerations and Equipment Reliability

Controls and Operation

Adaptablity to Remote Operation

Number of Process Steps

Feasubility for Production

Feed Limitations

State and Type of Oevelopment

Process

Equ'pinent

Type of Development

Scale of Development

Development Time Requíred (from intiation of program)

Safety

Stability and Atmospheric of Process Steps Pyrophoricity, Exothermic, and Exp?asion Considerations

Personnel Radiation Exposure

Process Requirements

Secondary Wastes and of fases

Production Capacity

Process Additives and Auxiliary Materials

Process Versatility and Control

Quallty Assurance

Utilities (air, power, water, etc*

Manpower

Facllity Requirements.

Noncontact Facilitios (remote)

Contact Facilities (hands-on)

Estimated Capital Cost

Total
Factor Weighting Rating Assigned

\begin{tabular}{|c|c|c|}
\hline Sub & ota & Sub \\
\hline & 60 & \\
\hline $\begin{array}{r}5 \\
5 \\
12\end{array}$ & & $\begin{array}{l}15 \\
40 \\
72\end{array}$ \\
\hline $\begin{array}{r}8 \\
15 \\
5 \\
5 \\
5\end{array}$ & & $\begin{array}{r}56 \\
105 \\
25 \\
35 \\
25\end{array}$ \\
\hline
\end{tabular}

40

275

30

80

50

70

45

40

330

10

20

90

160

10

80

30

139

25

24

15

20

15

15

25

30

210

10

80

80

50
373 0 5 5 
TABLE A.4. Inductoslag Ingot Mode System Evaluation - Evaluator B

Factor Weighting Rating Assigned

Complexity of Process

Material Handling

Consolidation Mode

Sub $\frac{\text { Total }}{60}$

Reliability

Controls and Operation

Adaptability to Remote Operation

Number of Process Steps

Feasibility for Production

Feed Limitations

State and Type of Development

Process

Equi pment

Type of Development

Scale of Development:

Development Time Requitred (f rom inituation of program)

Safety

Stability and Atmosphere of Process Steps

Pyrophoricity , Exothermic, and Explosion Considerations

Personnel Radiation Exposure

Process Requirements

Secondary Wastes and off Gases

Production Capacity

Process Additives and Auxiliary Materials

Process Versatility and Control

Quality Assurance

utilities (air, power, water, etc*)

Manpower

Facllity Requirements

Noncontact Facilities (remote)

contact Facilities (hands-on)

Estimated Capital Cost

Total
5

5

12

sut $\frac{\text { Total }}{304}$

15

35

60

$8 \quad 64$

15

5

75

15

20

20

40

225

25

70

50

40

40

40

200

10

20

70

100

10

30

30

160

25

20

40

30

15

15

15

30

190

60

a0

50

10

1079 
TABLE A.5. Inductoslag Ingot Mode System Evaluation - Evaluator D

Complexity of Process

Factor Weighting Rating Assigned

Material Handiling

Sub Total Sub lotal

Consolidation Mode

60

$22 B$

Maintenance Considerations and Equitament Relliability

Controls and Operation

Adaptability to Remote Operation

Number of Process 5teps

Feasibility for Production

Feed Limitations

$\begin{array}{rr}5 & 15 \\ 5 & 15 \\ 12 & 48 \\ 8 & \\ 15 & 40 \\ 5 & 45 \\ 5 & 15 \\ 5 & 30 \\ & 20\end{array}$

State and Type of Development

40

220

Process

Equ i pment

Type of Develupment

Scale of Develapment

Development Time Required (from

initiation of program)

Safety

40

150

Stability and Atmosphere of Process Steps

10

Pyrophoricity, Exothermic, and Explosion

20

80

Cons iderations

Personnel Radiation Exposure

10

30

10

50

50

50

40

Process Regulirements

30

172

Secondary Wastes and off Gases

Production Capacity

Process Additives and Auxiliary Materials

Process Versatility and Control

Quality Assurance

Utilities (air, power, water, etc.)

Manpower

Facility Requirements

Noncontact Facilities (remote)

10 
TABLE A.E. Inductoslag Casting Mode System Evaluation - Evaluator A

Factor Weighting Rating Assigned

Complexity of Process

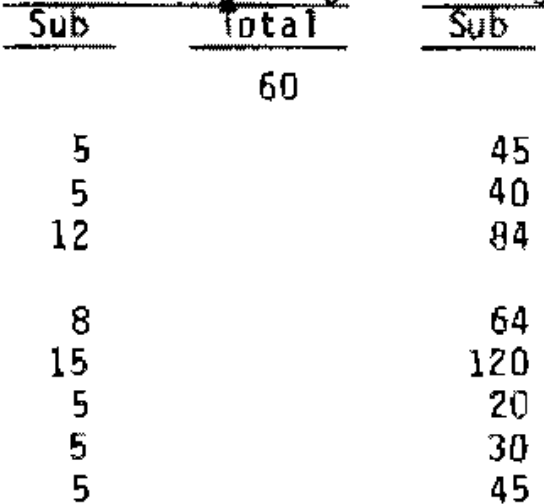

Material Handing

Consolidation Made

Maintenance Considerations and Equipment Reliability

Controls and Operation

Adaptability to Remote Operation

Number of Process Steps

Feasibility for Production

Feed Limitations

40

295

State and Type of Development

Process

Type of Thevelopment

Scale of Development

Development Time Required (from

initiation of program)

Safety

40

300

Stability and Atmosphere of Process Steps

Pyrophoricity, Exothermic, and Explosion

Process Requi rements

30

162

Secondary Wastes and Off Gases

Production Capacity

Process Additives and Auxiliary Materials

Process Versatility and Control

Quality Assurance

Utilities (ar, power, water, etc.)

Manpower

Facility Requirements

30 
TABLE A.7. Inductoslag Casting Mode System Evaluation - Evaluator 8

Complexity of Process

Material Handling

Consolidation Mode

Malntenance Considerations and Equîpment Reliability

Controls and Dperation

Adaptability to Remote Operation

Number of Process Steps

Feasibility for Production

Feed Limitations

State and Type of Development

Process

Equipment

Type of Levelopment.

Scale of Development

Development Time Required (from

initiation of program)

5afety

Stablity and Atmosphere of Process Steps

Pyrophoricity, Exothermic, and Explosion Considerations

Personnel Radiation Exposure

Process Reguirements

Secondary Wastes and Off Gases

Production Capacity

Process Additives and Auxiliary Materials

Process Versatility and Control

Quality As surance

Utillties (air, power, water, etc.)

Manpower

Facijity Reguírements

Nancontact Facilltues (remote)

Contact Facllities (hands-on)

Estinated Capital cost

Tota?
Factor Weighting Rating Assigned

60

314

\section{5}

5

12

20

35

60

8

64

15

10

25

25

40

230

30

5

10

10

10

5

40

220

10

20

90

100

10

30

30

113

5

4

5

5

3

3

30

10

100

10
100

25
4
25
25
12
12
10

50 
TABLE A.8. Inductoslag Casting Mode Systern Evaluation - Evaluator C

Complexty of Process

Material Handling

Consalidation Mode

Aaintenance Considerations and Equipment Reliability

Controls and Operation

Adaptalility to Remote Operation

Number of Process Steps

Feasibility for Production

Feed Limitations

State and Type of Development

Process

Equipment

Type of Oevelopment

Scale of Development

Development Time Required Ifrom

initiation of program)

Safety

Stabllity and Atmosphere of Process Steps

Pyrophoricity, Exothermic, and Explosion Considerations

Personnel Radiation Exposure

Process Requirements

Secondary Wastes and off Gases

Production Capacity

Process Additives and Auxiliary Materials

Process Versatility and Control

Quality Assurance

Utilities (air, power, water, etc.)

Manpower

Facllity Reguirements

Noncontact Facilities (remote)

Contact Facjlities (hands-on)

Estimated Capital Cost
Factor Weighting Rating Assigned

$\begin{array}{rrr}\text { Sub } & \frac{\text { Total }}{300} & \\ & & \\ 5 & & 25 \\ 5 & & 50 \\ 12 & & 96 \\ & & \\ 8 & & 64 \\ 15 & & 90 \\ 5 & & 25 \\ 5 & & 40 \\ 5 & & 25\end{array}$

40

270

20

80

50

80

40

40

240

10

20

90

100

10

50

30

205

5

4

5

5

3

3

5

30

230

10

10

80

100

10
415

\section{0}

00 
IABLE A.9. Inductoslag Casting Mode System Evaluation - Evaluator D

Complexity of Process

Material Handling

Consolidation Mode

Maintenance Considerations and Equipment Rellability

Controls and operation

Adaptability to Remote 0peration

Number of Pracess Steps

Feasibility for Production

Feed Limitations

State and Type of Devel apment

Process

Equipment

Type of Development

Scale of Development.

Development Time Requiled (from

initiation of program)

Safety.

Stability and Atmosphere of Process Steps

Pyrophoricity, Exothermic, and Explosion Considerations

Personnel Radiation Exposure

Process Requirements

Secondary Hastes and off Gases

Production Capacity

Process Additives and Auxiliary Materials

Process Versatility and Control

Quality Assurance

Utilities (air, power, water, etc.)

Manpower

Facility Requirements

Noncontact Facilities (remote)

Contact Facilities (hands-on)

Estimated Capital cost

Total
Factor Weighting Rating Assigned

Sub $\frac{\text { lotal }}{60} \quad \frac{\text { Sub }}{272}$

$\begin{array}{rr}5 & 25 \\ 5 & 15 \\ 12 & 72 \\ 8 & \\ 15 & 40 \\ 5 & 60 \\ 5 & 10 \\ 5 & 25 \\ & 25\end{array}$

40

220

50

50

50

40

4D

150

10

80

20

40

10

30

30

143

25

20

35

30

9

9

15

30

130

30

80

20
10

10

5

2

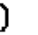

.

(1)

5


APPENDIX $B$

NONCONSUMABLE ELECTRODE MELTING 
APPENDIX B

\section{NONCONSUMABLE ELECTRODE MELTING}

\section{INTROOUCTION}

The nonconsumable electrode melting process can melt a variety of metals of various sizes without contamination from either the electrode or the crucible. Arc melting is achieved by a water-cooled electrode (Figure B.1). The heart of the system is the Rototrode (Figure B.2); this rotating, currentconducting electrode is electrically and mechanically coupled to a nonconsumable arc-generating surface. The electrode functions without being consumed by the melting arc because of a phenomenon called "arc locking" and because of the ability of the arc-generating surface to be in continuous motion relative to the arc itself. Arc locking can be accomplished geometrically or magnetically, depending on the particular application. The electrode tip is removable and replaceable.

Furnace dc power is supplied by silicon-controlled rectifiers (SCRs) for efficient current regulation and response. A separately valved vacuum chamber allows continuous charging and controlled feeding of process materials. The melt chamber can be operated at vacuums in the micron range or at higher pressures. The arc position is controlled by a joint that allows remote manipulation in the $x, y$, and $z$ axes. An electrohydraulic servo maintains arc voltage at a predetermined or programed level. The electrode and melt pool are monitored.

\section{PROCESS DESCRIPTION}

This furnace can be operated with different material feeding modes, and it can be used to produce ingots or to cast molten metal into molds or canisters (Figure B.3). One such mode or operational scenario is depicted in Figure B.4. In this batch melting process, a drum containing process material is placed in

- Patented device and trademark of Retech, Inc., Ukiah, California. 


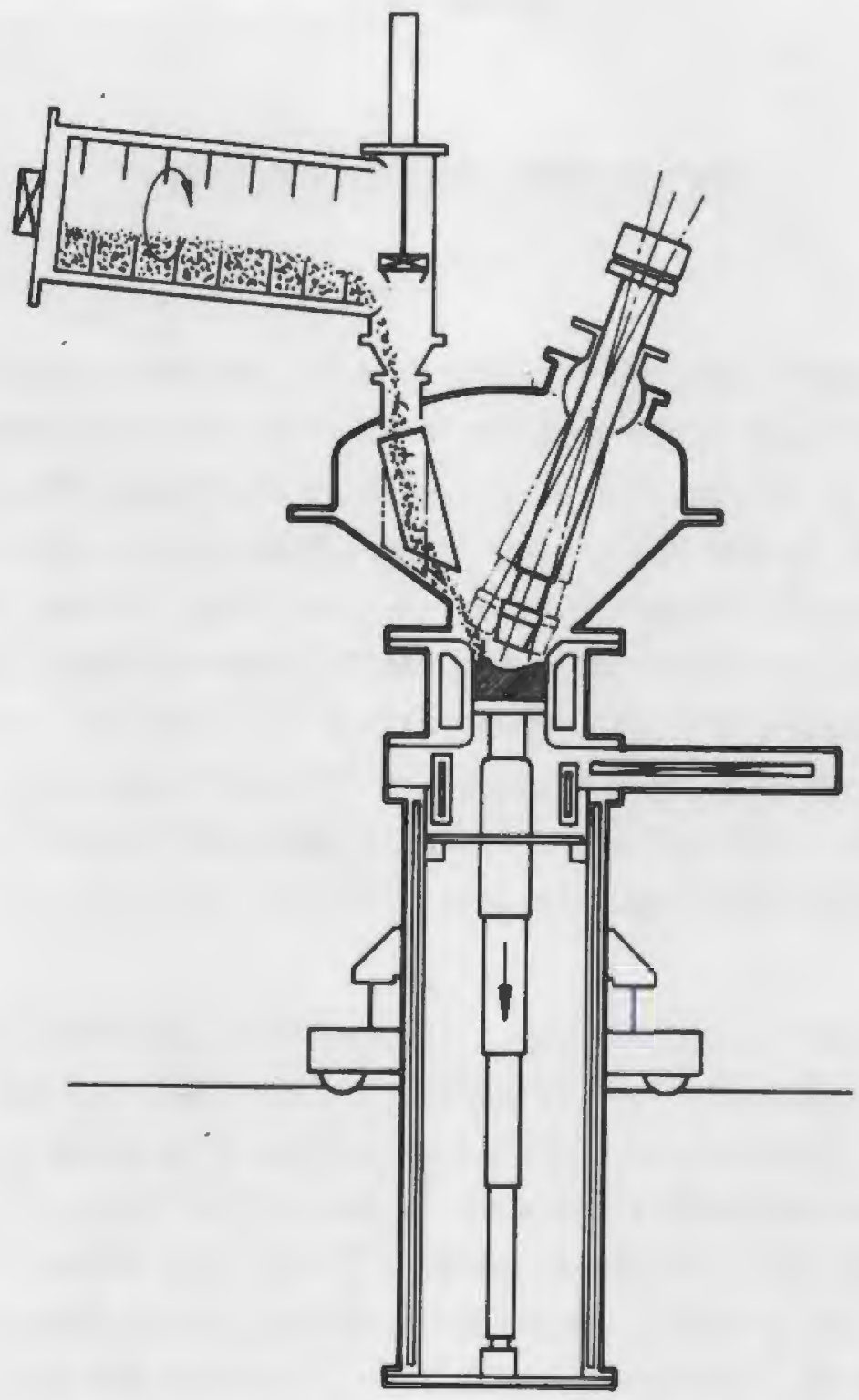

FIGURE B.1. Nonconsumable Electrode Furnace

the crucible and melted. This step is repeated until the crucible is full or until the desired batch size is obtained. The batch is then cooled and removed from the crucible.

In another operational mode (Figure B.5), the process material is fed into the crucible on a continuous basis after the initial charge is melted. The batch of metal is then cooled and handled in the same way as in the first scenario. 


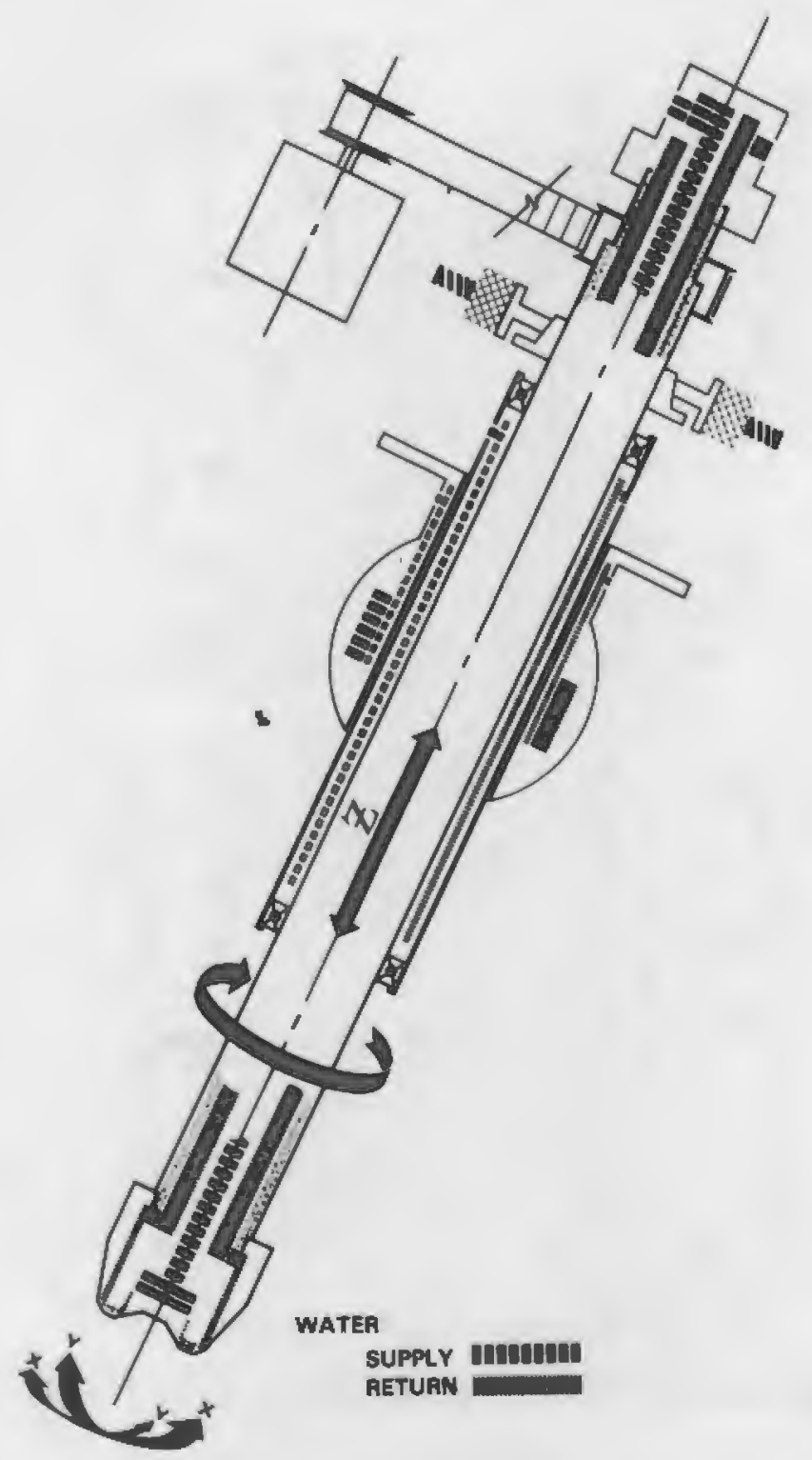

FIGURE B.2. Rototrode Electrode for Nonconsumable Electrode Melting System

In the melt-and-pour mode of operation (Figure B.6), the process metal is fed into the furnace as in the previous scenario. However, when the desired melt size is obtained, it is poured into a mold or container. This batch process is repeated until the container is full. 

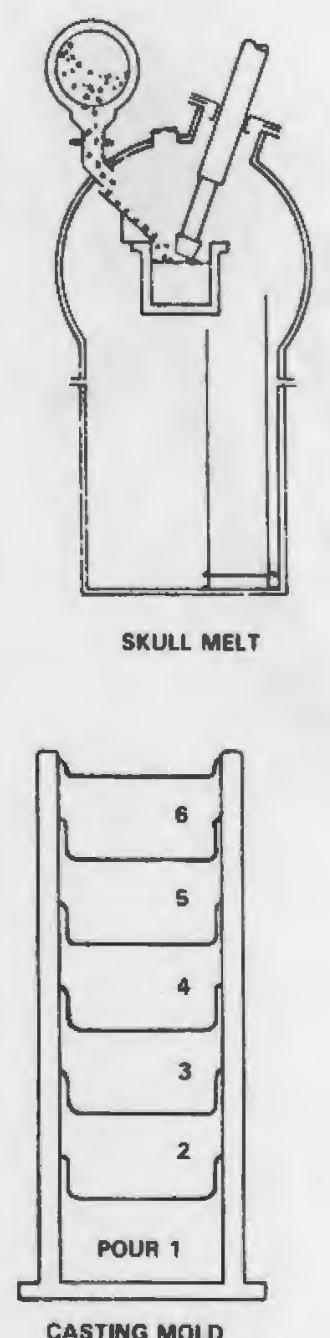

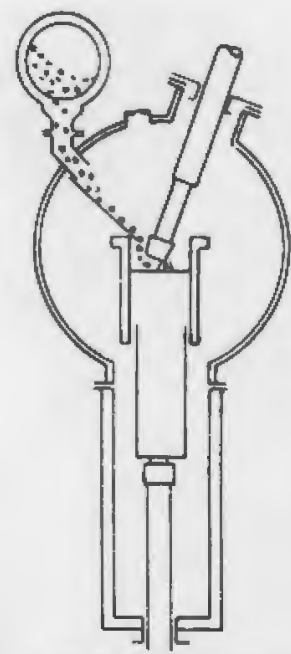

WITHDRAWAL MELT

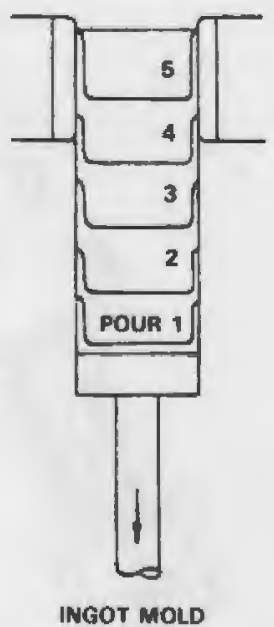

INGOT MOLD

FIGURE B.3. Operational Modes for Nonconsumable Electrode Furnace

In another mode of operation (Figure B.7), the process material is continuously fed from the charge hopper into the furnace crucible, and the solidified metal is withdrawn from the bottom of the crucible as one continuous ingot. An ingot of the desired diameter and length can be produced in one basic operation.

\section{PROCESS NEEDS AND REQUIREMENTS}

The nonconsumable electrode melting process will consolidate and solidify the metallic wastes identified in the Process Material Identification section (p. 16). It will be required to produce -105 ingots ( $2 \mathrm{ft}$ in diameter by $10 \mathrm{ft}$ 


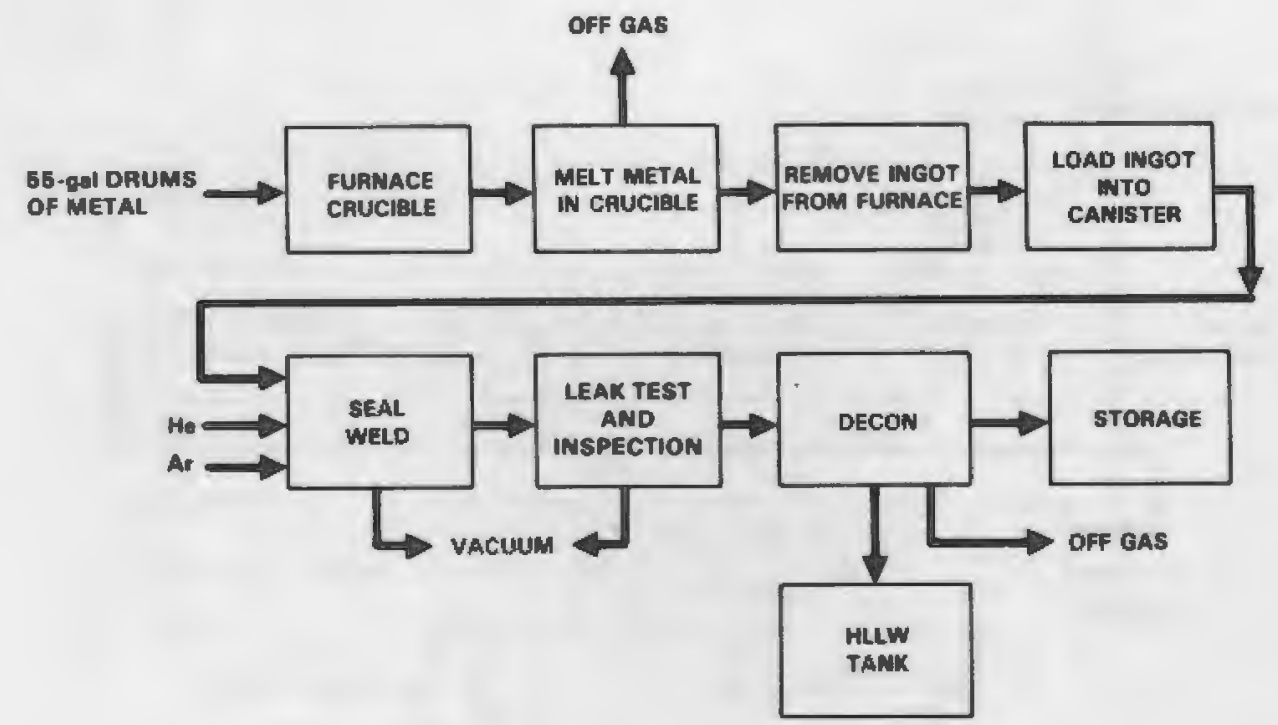

FIGURE B.4. Batch Skull Melting by Adding 55-gal Drums of Metal

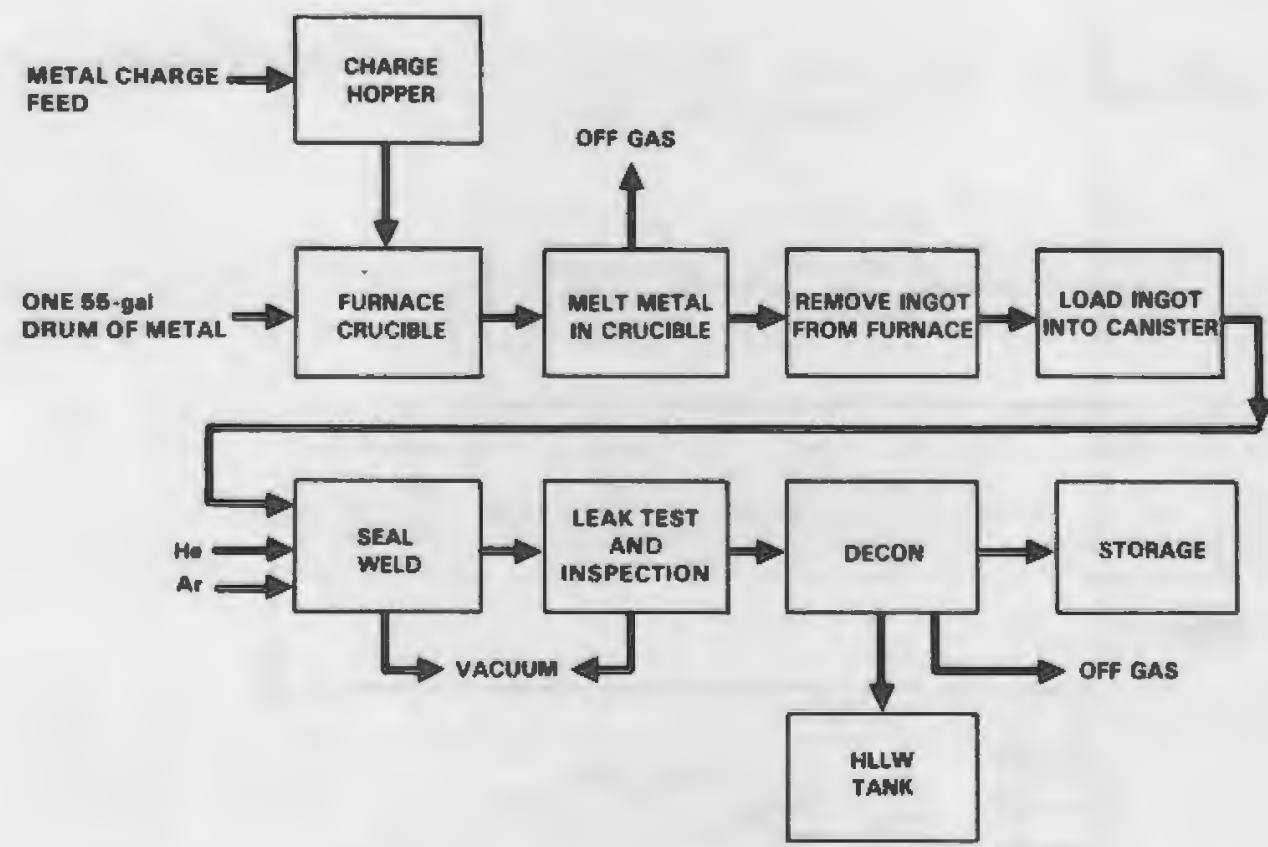

\section{FIGURE B.5. Batch Skull Melting with Continuous Feeding}

long) or equivalent in a maximum of 300 days, and the facility could be operated $24 \mathrm{~h} /$ day. The canisters containing the consolidated process metallics are to be suitable for remote handling and transport and compatible with long-term disposal in a geologic repository. 


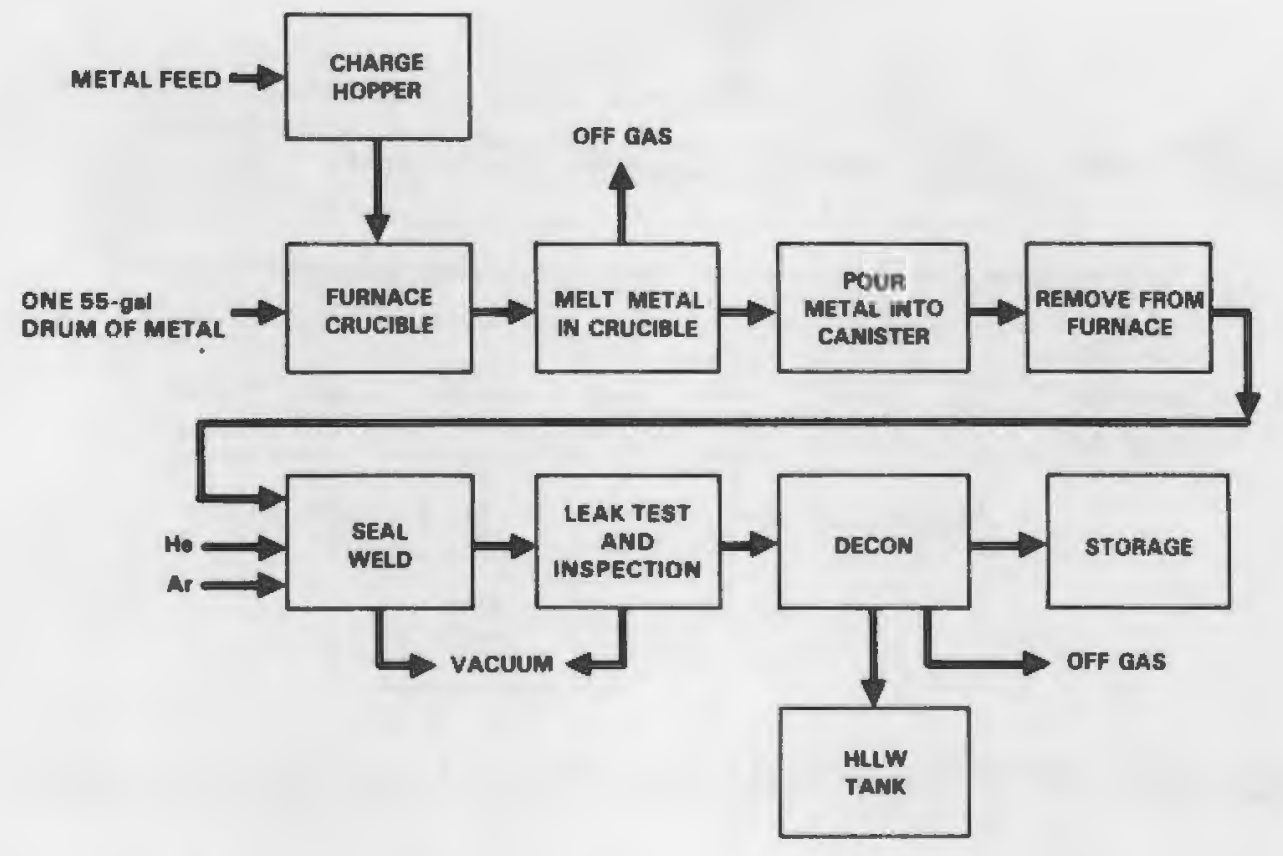

FIGURE B.6. Batch Skull Melting with Continuous Feeding; Melt Poured Into Canister

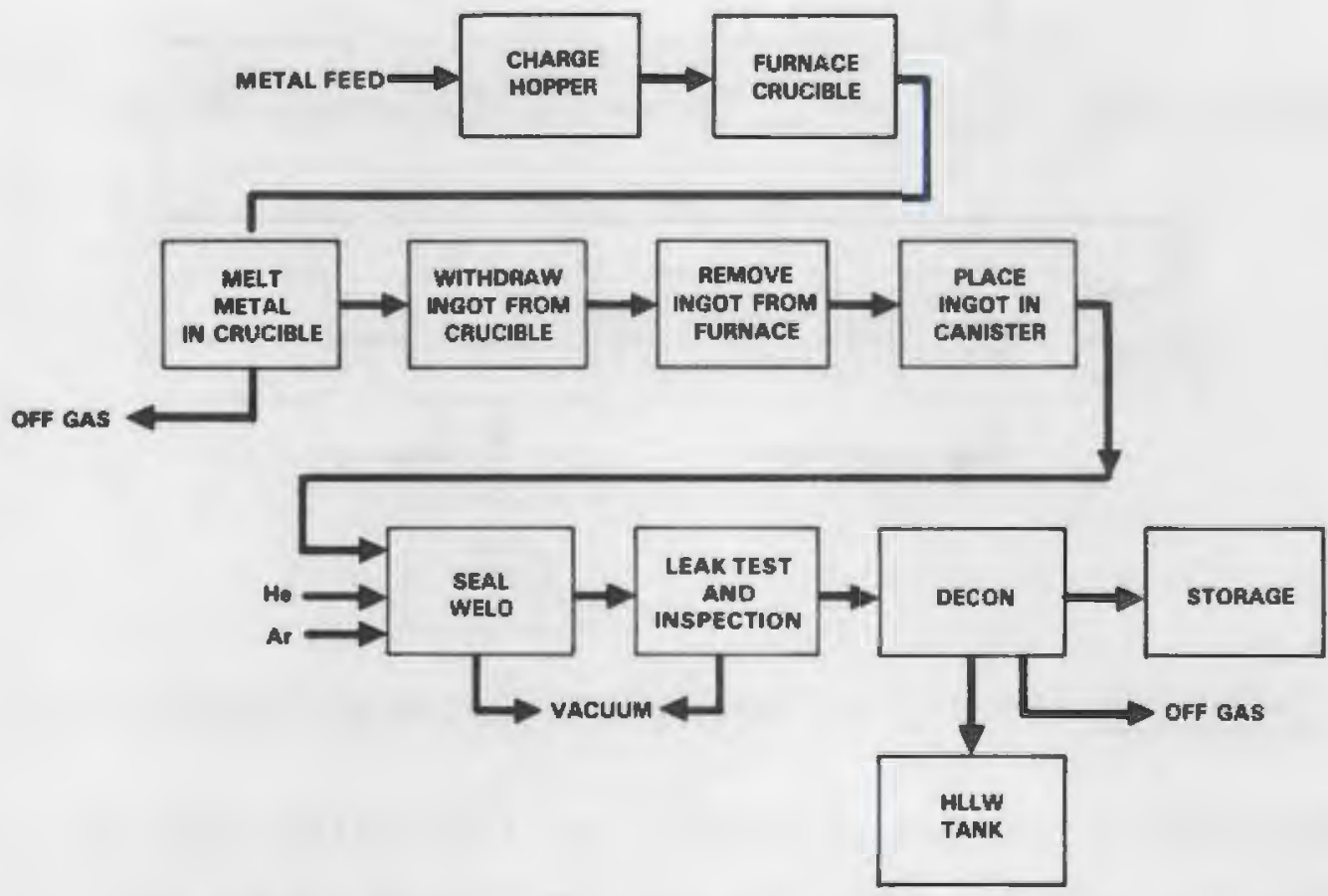

FIGURE B.7. Batch Skull Melting with Continuous Feeding; Ingot Withdrawn from Bottom 


\section{Furnace Feed}

Provisions and equipment to remotely handle and move the process material (hulls and miscellaneous metallic components) to the furnace will be similar to those identified in Appendix A. Cranes and hoists will be used to handle shielded casks and drums of metal. Provisions to empty the drums into a charge hopper and/or charge the full drums into the furnace crucible will be required. No flux feed provisions will be required for this melting process.

\section{Furnace}

A view of a furnace concept developed and designed to melt contaminated materials is shown in Figure B.8 (Beitel and Schlipphacke 1978). The furnace contains a centrifugally cast chrome-copper crucible large enough to hold a 55-gal drum containing metal parts. All interior surfaces of the double-walled chamber slope downward; external connections are accessible for remote operation; and the electrode is the only moving part that extends through the vacuum chamber wall (Figure B.9).

The nonconsumable direct arc electrode is designed for a minimum of $40 \mathrm{~h}$ of operation at $750 \mathrm{kVA}$ between tip replacement. The electrode is cooled by a high-pressure, closed loop, deionized water system. It is mounted to provide three-dimensional movement within the crucible with adequate travel to initiate an arc $-1 \mathrm{~m}$ above the crucible bottom (at the top of the scrap charge) and follow the molten pool to within $15 \mathrm{~cm}$ of the crucible bottom. During meltdown, a sweeping movement around the crucible is required to melt all scrap and yet prevent localized overheating.

A furnace designed for batch skull melting (Figures B.8 and B.9) could melt the projected annual facility throughput in 341 days. Batches of $-250 \mathrm{~kg}$ would be melted to form a 1000-kg ingot that would be cooled and removed from the furnace. Based on engineering studies, six such ingots could be made in 69 to $70 \mathrm{~h}$. The six ingots would fill a $2-\mathrm{ft}$ diameter by 10-ft long canister $\sim 98 \%$ ful1; 118 canisters would be required for the annual facility throughput.

A furnace designed for batch skull melting with continuous feed as depicted in Figure B.5 could melt the annual facility throughput in $\sim 152$ days (see Figure B.10). In this process, the feed material is continuously fed into 


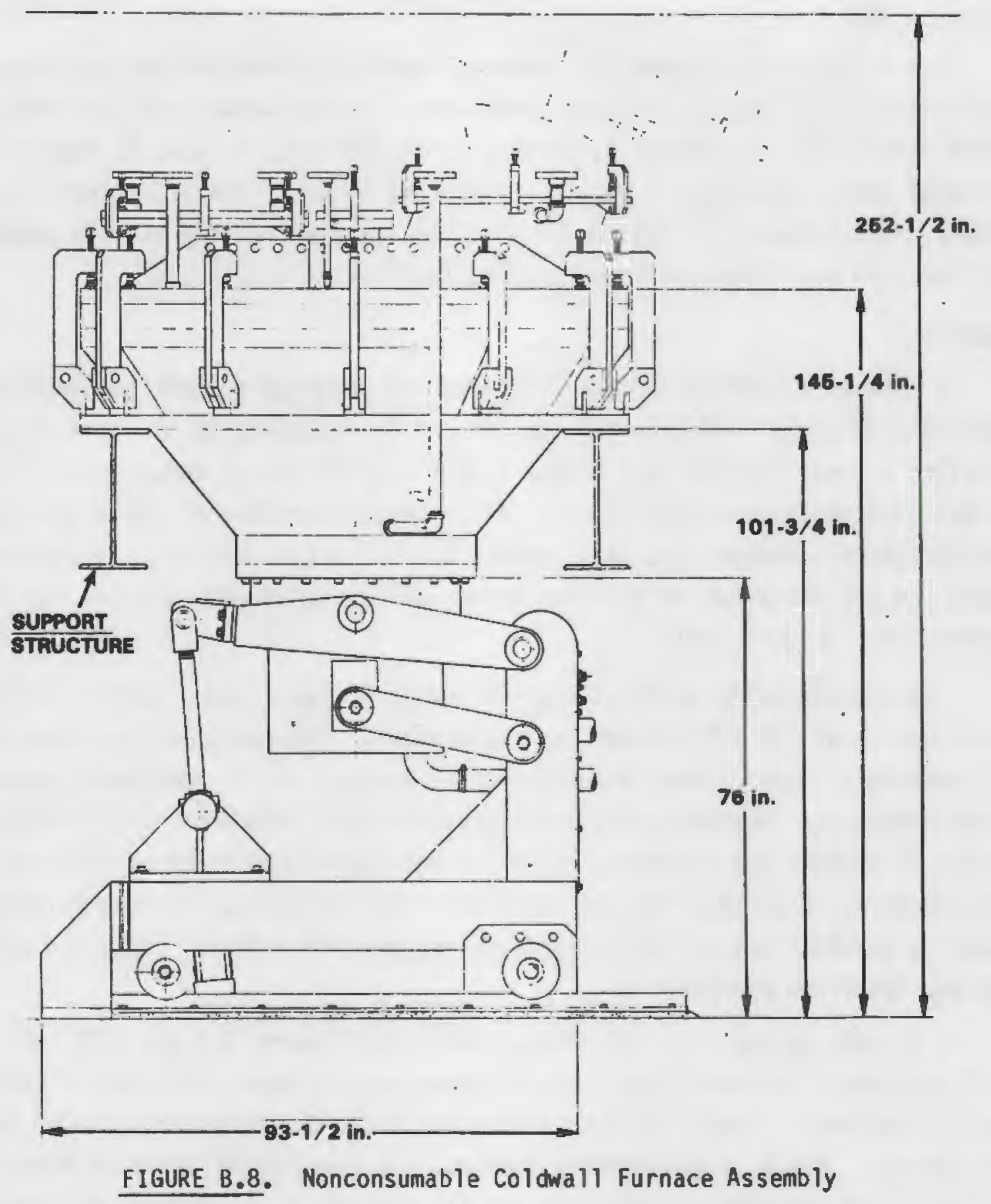




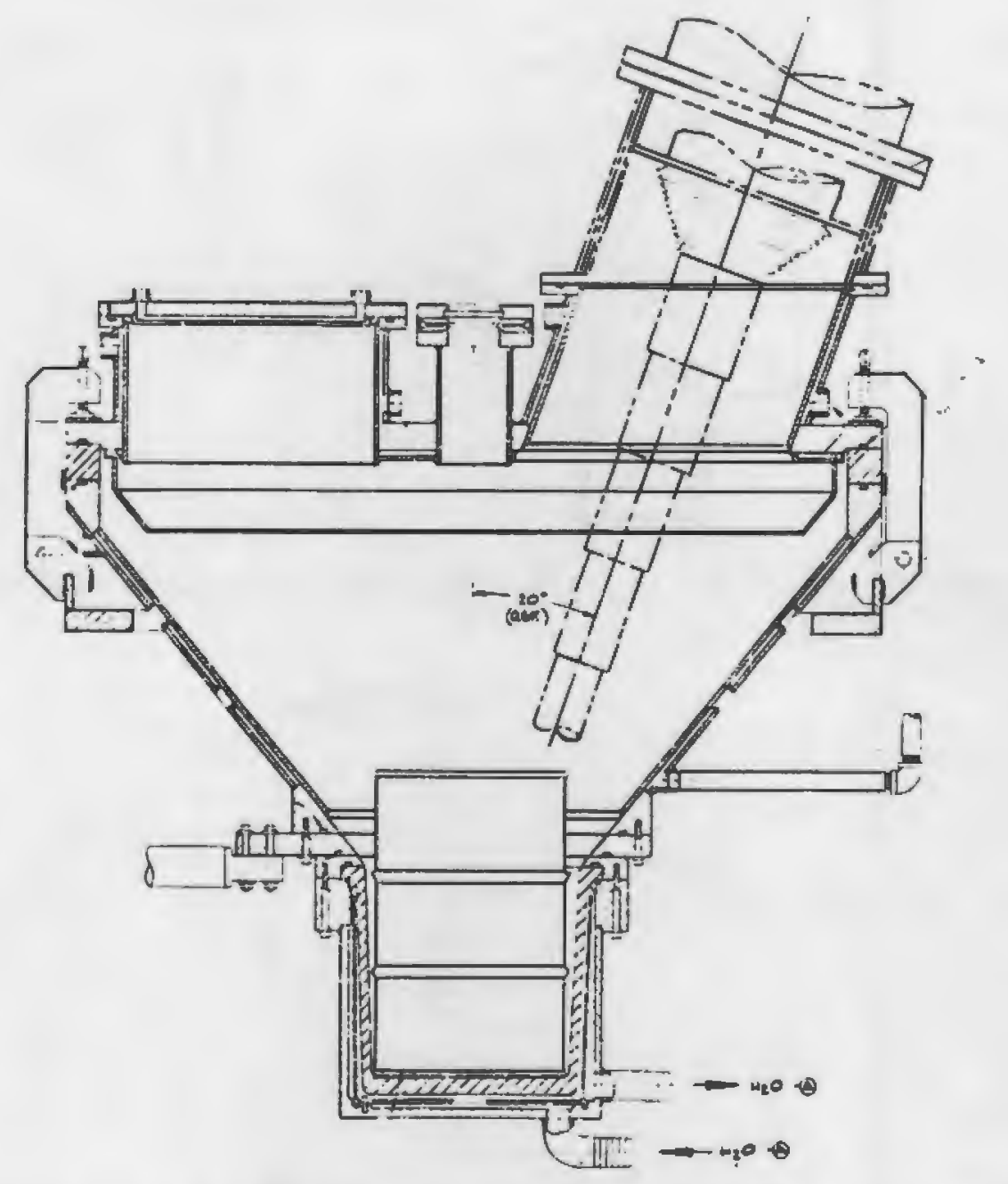

FIGURE B.9. Nonconsumable Coldwall Furnace Melt Chamber Assembly

the crucible after the initial charge is melted. When an 1100-kg ingot is formed, it is cooled and removed from the furnace. It has been estimated that five of these ingots could be made in 31 to $32 \mathrm{~h}$. Five ingots would fill a 2-ft diameter by 10-ft long canister $90 \%$ full; 117 canisters would be required for the annual facility throughput.

The furnace concept depicted by the flow diagram in Figure B.6 is illustrated in Figure B.11. It has been estimated that this skull melt-and-cast process could handle the annual facility throughput in 131 days. Feed material is continuously fed into the crucible after the initial charge is melted until $-1100 \mathrm{~kg}$ of metal has been melted. The crucible is then tilted and $-725 \mathrm{~kg}$ of 


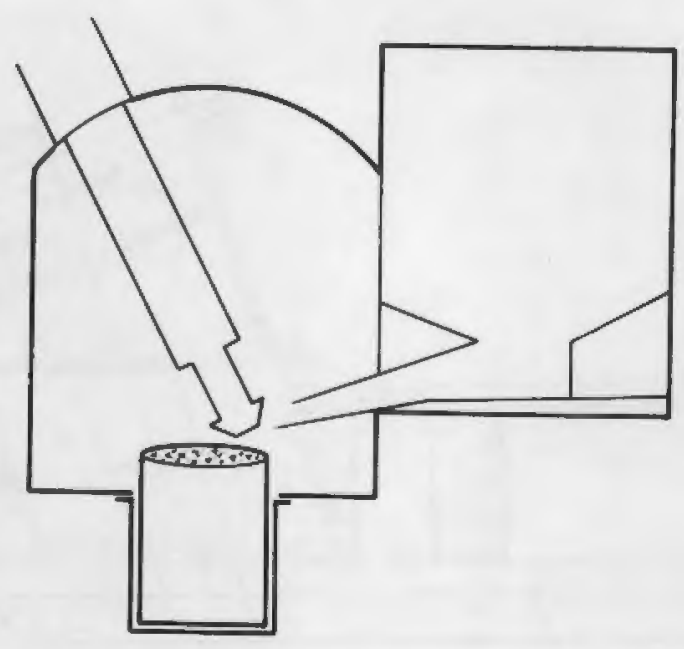

FIGURE B.10. Batch Skull Melting with Continuous Feeding

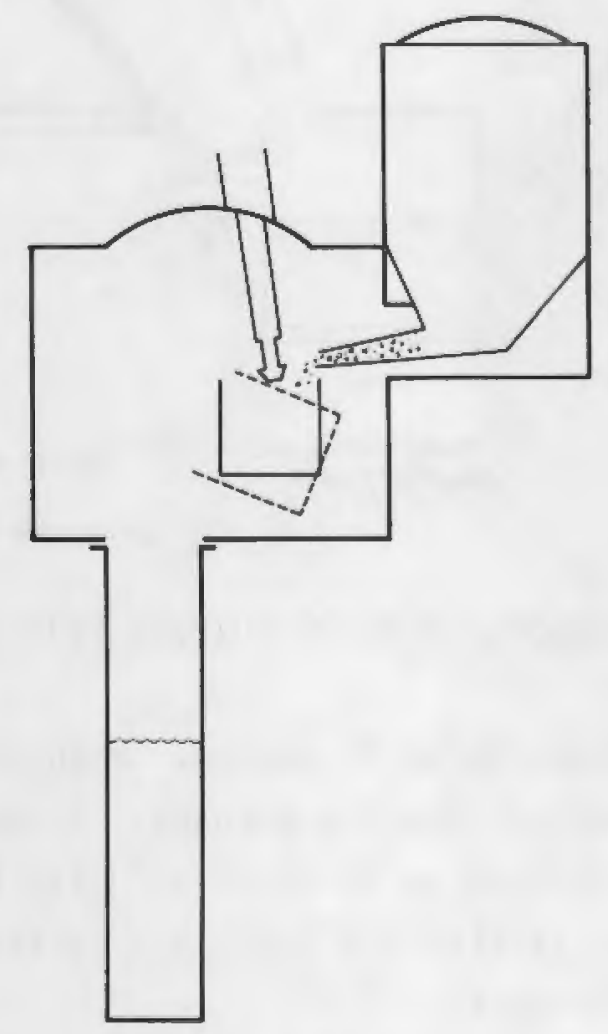

FIGURE B.11. Batch Skull Melting; Melt Poured Into Canister 
metal is poured into a canister. Eight of these pours would fill a 2-ft diameter by $10-\mathrm{ft}$ long canister $95 \%$ full in 28 to $29 \mathrm{~h}$; 111 canisters would be produced annually.

It has been estimated that a furnace of the concept shown in Figure $B .1$ using the ingot withdrawal mode depicted in Figure $B .7$ could process the required annual throughput in 92 days. An $\sim 5550-\mathrm{kg}$ ingot could be produced every 19 to $20 \mathrm{~h}$. This ingot would be sized so it could fill a 2-ft diameter by $10-\mathrm{ft}$ long canister $\sim 90 \%$ full; 116 canisters would be produced every year.

A furnace $\sim 3 \mathrm{~m}$ in diameter and $7 \mathrm{~m}$ high would be required for the batch skull melting mode. It has been estimated that a furnace $3 \times 5 \times 7 \mathrm{~m} \mathrm{high}$ would suffice for the batch skull melting and ingot withdrawal with a continuous feed scenario. A furnace $5 \times 5 \times 8 \mathrm{~m}$ high will be required for the skull melt-and-pour mode.

Ingot/Canister Handling and Transport

A cart mechanism such as that shown in Figure $B .8$ could be used for remote batch charging of the furnace and for removal of the ingot from the batch skull melting modes. However, the sequences, equipment, and arrangements identified in Appendix A for the processing of Inductoslag ingots and/or canisters will also be applicable and adaptable for any one of the operating scenarios of the nonconsumable electrode melting process.

\section{FACILITY REQUIREMENTS}

Since the size of a furnace for any one of the identified operational modes could be up to twice as large as the Inductoslag furnace, this process will require more hot cell and operational space than that identified in Appendix A. Off-Gas System

The off-gas system will cool the gases generated during the melting operation and filter out any particulates or volatile fission products that may enter the system. The equipment will be similar to that identified for the Inductoslag process. The estimated flow rates and constituents of an off-gas system for this furnace and its hot cell are summarized below: 


$\begin{array}{ll}\frac{\text { Effluent }}{\text { Gases(a) }} & \frac{\text { Flow Rate }}{85 \mathrm{~m}^{3} / \mathrm{min}} \\ \text { Particulates (b) } & 4.0 \mathrm{~kg} / \mathrm{h}\end{array}$

(a)From furnace at $600^{\circ} \mathrm{C}$ and $1 / 3$ atm. (b) Metal fumes contaminated with radioisotopes.

Secondary Wastes Requiring Processing

Wastes from this melting system that will require processing are listed below:

$\frac{\text { Material }}{\text { Nonradioactive cooling water }}$
Process wastes
Ventilation flow

$\frac{\text { Amount }}{900 \ell / m i n}$
$10 \mathrm{~kg} / \mathrm{h}$
$600 \mathrm{~m}^{3} / \mathrm{min}$

Utilities, Services, and Materials

Estimates of the normally required utilities, services, and materials that will be needed for this melting system are noted below and summarized in Table B.1.

\section{Power Supply}

The electrode power supply will consist of two systems each with a capacity of $7500 \mathrm{~A}$ at $70 \mathrm{~V}$ each, providing a nominal heating capacity of $500 \mathrm{kH}$. The power supply is a solid-state SCR unit.

\section{Water-Cooling System}

Water cooling will be applied to the crucible, chamber, electrode, and subsystems to prevent overheating. Because the projected duty cycle (power on) will be low (10\%), once-through cooling will be adequate. A maximum flow rate of $900 \mathrm{2} / \mathrm{min}(230 \mathrm{gpm})$ will allow a maximum water temperature increase of $20^{\circ} \mathrm{C}$. A closed loop water system could reduce the usage to $53 \mathrm{l} / \mathrm{min}$ (14 gpm) to cool the heat exchanger. 
IABLE B.1. Utilities, Services, and Materials for Nonconsumable Electrode Melting Process

\begin{tabular}{|c|c|c|c|}
\hline It em & Capacity & Average Rate & Amount/Year \\
\hline Electricity & $900 \mathrm{~kW}$ & & \\
\hline Water & 1500 \&/mị & 1000 \&/min & \\
\hline Air & $950 \mathrm{~m}^{3} / \mathrm{m} 1 \mathrm{n}$ & $600 m^{3} / m i n$ & \\
\hline Steam & $15 \mathrm{~kg} / \mathrm{min}$ & $2 \mathrm{~kg} / \mathrm{min}$ & \\
\hline Canisters & $2 \mathrm{ft}$ dia $\times 10 \mathrm{ft}$ long & & $111,117,118$, or 133 \\
\hline He sources & & & $120,130,130$, or 150 \\
\hline Argon & & $60 \mathrm{e} / \mathrm{m}$ T⿱ n & $12,000 \mathrm{~m}^{3}$ \\
\hline
\end{tabular}

Hydraulics $\quad 38 \mathrm{k} / \mathrm{min}$ at

Vacuum, Argon, and Air Systems

The pumping system shown in figure $B, 12$ will produce and maintain a base pressure of 1.0 Pa. Two paralle1, two-stage pumping systems w11 each consist

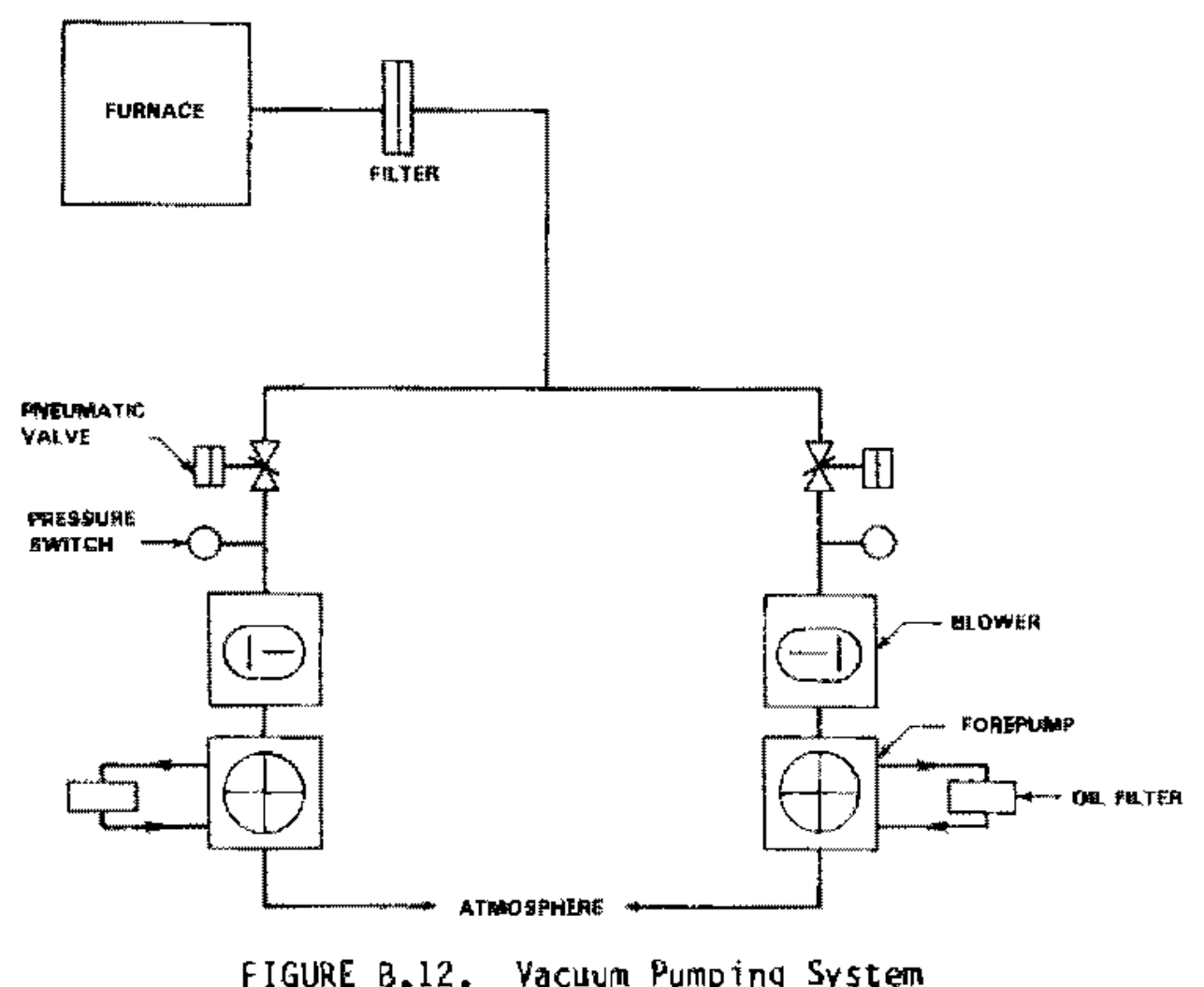

B. 13 
of a mechanical booster pump and a compatible backing pump. An argon system with a capacity of $\sim 60 \mathrm{\ell} / \mathrm{min}$ will be required to provide a flush stream past the viewing window and the insulator (Figure B.13). The air system provides for a fixed vacuum above background, if desired, and backfill capability. A $1400-\ell / s \quad(3000-c f m)$ blower will provide a slightly negative pressure within the furnace chamber whenever the chamber is opened to prevent metallic dust (or finely divided oxides) from flowing into the room.

\section{Viewing System}

Visual observation of the direct arc and molten metal zone is required to control electrode movement in the $x-y$ plane. Positioning in the $z$-plane during operation is servo-controlled from the arc voltage. The viewing system can be based on a video camera or passive optics, depending on final facility layout.

\section{Jet Cleaner}

When steel scrap is arc melted, as much as 2 wt\% of the charge is vaporized or volatilized. In a vacuum, most of these fumes are deposited on the cold walls above the melt. This deposit is a poorly adherent, soot-like, finely divided metal powder. By initially coating the clean walls with a detergent film, the adhesive power of the metal particulates can be further reduced. A jet cleaner that can be operated with water or steam at pressures up to $30 \mathrm{MPa}$ (4000 psi) will be used to clean the furnace interior. The nozzles spray in a three-dimensional pattern and can reach almost every internal chamber surface.

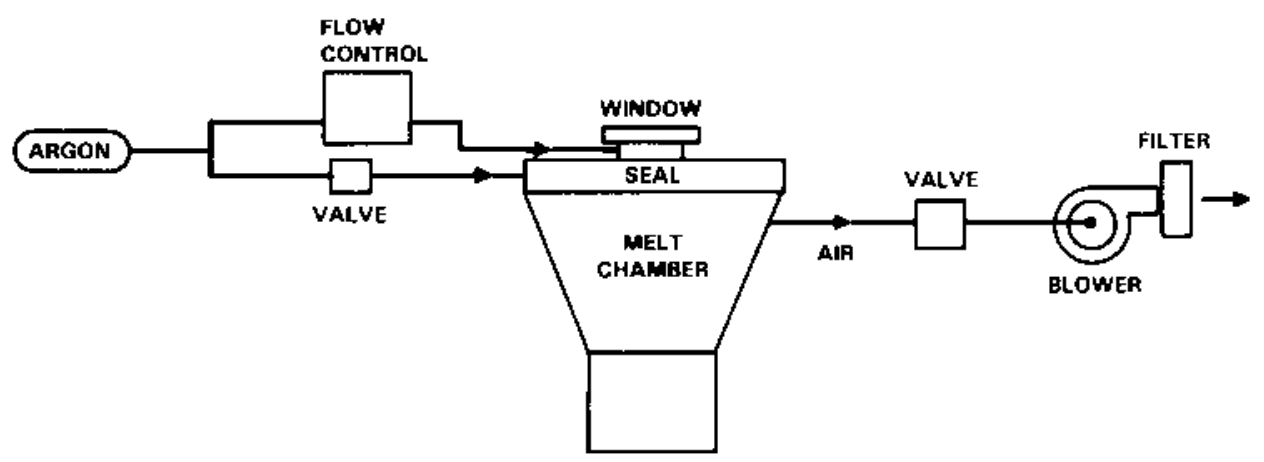

FIGURE B.13. Argon and Air System 


\section{ASSESSMENT DISCUSSION}

Four operational scenarios or modes for the nonconsumable electrode furnace have been identified. Based on the estimated time required to process the annual throughput, the number of individual product packages produced, and handling and encapsulation requirements, it was determined that the melt-and-pour mode of operation (Figure B.6) would be evaluated. The numerical ratings assigned to the process by the individual evaluators are presented in Tables B.2 through B.5 (see P. B.20). The criteria are discussed below. Complexity of Process

Equipment requirements, process control, and maintenance considerations indicate that the nonconsumable electrode melting furnace will be generally more rugged but will present more operational complexity and maintenance problems than the reference Inductoslag furnace.

Material Handling. The steps and processes required to bring the process materials into the facility and feed them into this furnace are the same as those identified for the reference process. Less in-cell handling equipment will be required for this process because there are no starting stubs to be separated from the ingot/casting and recycled or any flux to be recycled. Canisters will be loaded in the furnace, and no ingots will be moved or transported outside a canister. Fewer canisters will be handled and processed (about one-fourth as many as for the reference process).

Consolidation Mode. The nonconsumable electrode melting process provides a contamination-free heat source that can operate in a vacuum or at low positive pressures. Mechanisms are required to move the electrode in three planes, feed the process material, and pour the molten metal. All functions are performed in a controlled atmosphere.

Maintenance Considerations and Equipment Reliability. The overall reliability of the equipment required for this melting system is considered to be better than that of the reference Inductoslag system. Although the electrode and its system are quite involved (with the exception of the electrode tip), they have proved to be long lived in production. Tips will require changing after $\sim 40 \mathrm{~h}$ of melting time. The crucible for this furnace is not as 
vulnerable to damage as that of the reference process, and the tilt-and-pour mechanism is considered to be at least as reliable as the ingot withdrawal system. Less maintenance will be required for this system than for the reference process because less remote equipment is required.

Controls and Operation. The controls for and the operation of this furnace are more involved and complex than those for the reference furnace due to the type of electrode and the continual monitoring and manipulation that are required during the melting cycle. The metal feed will be similar to that of the reference process, but no flux feeding is required for this process. The tilt-and-pour operation is a batch-type process that must be initiated at a certain phase of the furnace cycle. Fewer furnace feed operations are needed because no fluxes are required. Since no uncased ingots and fewer canisters of material are produced by this process, fewer batch-type operations and controls are required after melting.

Adaptability to Remote Operation. Like most melting systems, this furnace concept has been remotely operated in industries other than nuclear. A furnace designed for nuclear application has been fabricated but has not been placed in operation (Figures B.8 and B.9). With an adequate development, design, and testing program, no special problems are anticipated in using a production-size furnace in the remote nuclear operational model.

Number of Process Steps. About 48 operations are involved in filling a canister with molten metal after the required feed material is loaded in the hoppers. Fewer operations are required in the complete processing of one canister for this process than for the reference process (54 versus 64).

Feasibility for Production. All steps in the internal operation of the nonconsumable electrode furnace have been performed on a production scale. Some adaptations will need to be identified and incorporated in a fully remote nuclear application (radiation resistance, decontamination, and remote maintenance and replacement considerations). One furnace and its supporting systems are deemed adequate and feasible for the intended production. 
Feed Limitations. Material can be fed continuously or with controlled entry batches of at least $55 \mathrm{mgal}$ and $250 \mathrm{~kg}$. Thus, two feed systems could be used to feed various sizes of material; large, heawy pieces of material could be placed in an emply canister prior to its insertion into the furnace. State and Type of Development

Process and/or Equipment. Furnaces larger than the one required for this installation are in production operation in various industries. A furnace of a comparable size designed for use in a fully remote nuclear application has been fabricated but is not yet in operation (beftel and Schlipphacke 1978).

Type and Scale of Development. Developments that will be required prior to actual hot cell operation of a nonconsumable electrode furnace ĩnclude:

- investigate the capability of melting a variety of mixtures of metals

- determine off-gas tenperatures and the systen to adequately process the contaminated of $f$ gases and particulates

- test system(s) for the fully remote monitoring of the electrode and molten poor

- develop and demonstrate the remote cleaning of the inside of the furnace

- demonstrate remate operation and rellabflity of furnace

- identify means to remove and replace the furnace and components remotely

- demonstrate the removal and/or handling of crucible skull butldup

- demonstrate the remote handing of containers.

Development Time Required. The required design, fabrication, and testing could be done in a period of 30 months.

Safety

Three primary hazards are associated with the nonconsumable electrode melting system in addition to the normal concerns regarding the processing of radioactive materíal: 
- A water leak in the crucible or furnace jnterior during the melting of zirconium could result in a steam expansion and a simultaneous reaction of the molten metal and water, forming hydrogen. Explosive mixtures of hydrogen and air could be released to the surrounding area or cell.

- As compared with the reference process, this furnace system has an added potential source of water cantatined in the electrode above the surface of the molten pool.

- Finely divided metallic residues that deposit on interior melt chamber surfaces during normal melting (especially zirconium) are a potential fire hazard when the furnace chanber is opened or atr is introduced*

Other potential hazards (crucible failure, spills, etc, ) are caman to conventional melting of metals. For this process, it has been estimated that the moximum amount of molten metal would be $-1100 \mathrm{~kg}$. Its temperature could be as high as $1900^{\circ} \mathrm{C}$.

Since all radioactive material will be processed in shielded hot cells and devices designed for that purpose, the anount of excess radiation exposure will be function of equipment maintenance and replacement, process accidents, or equipment failures.

Process Requil rements

Secondary vastes and off Gases. The projected flow rates in this off-gas system 11 be about three times those in the reference process. Other requirements are essentially the same as for the reference process.

Production Capacity. One furnace is more than adequate to meet the projected throughput. This furnace concept could be expanded to handle significant throughput increases.

Process Additives and Auxiliary Materials/Utilities. No spectal fluxes or chemicals are required for this process. The water-cooling requirements per unit of metal throughput are 1 ess than the reference pracess by $15 \%$ to $20 \%$. 
However, this process will require about slx times more argon than the reference process. The power required per $\mathrm{kg}$ of metal will be about the same as for the reference process.

Pracess Versatility, and Control. Like the reference process, this process will handle and melt a wide range of metals and mixtures. Because this material is cast inside a container or canister, a wider range of metal mixes, batches, and foreign materials could be processed without imposing a potential quality contral problem of ingot or casting integrity.

Manpower. Due to a shorter furnace cycle than the reference process, this process will run -13 l days/yr.

\section{Facility Requirements}

The facility required to enclose and support this process is estimated to be *1.1 times bigger than that dentified for the reference process or facility. However, the complexity of the equipment installation will be similar to that of the reference process.

\section{REFERENCES}

Beitel, G. A., and 0. B. Schlipphacke. 1978. Vacusum Furnace Development

Plan. Rockwell Hanford Operations, Richland, Washington. 
TABLE B.2. Nonconsumable Electrode System Evaluation - Evaluator A

Complexity of Process

Material Handling

Consolidation Mode

Maintenance Considerations and Equipment Reliability

Controls and Operation

Adaptability to Remote Operation

Number of Process Steps

Feasibility for Production

Feed Limitations

State and Type of Development

Process

Equipment

Type of Development

Scale of Development

Deveiopment Time Required (from initiation of program)

Safety.

Stability and Atmosphere of Process Steps Pyrophoricity, Exothermic, and Explosion Considerations

Personnel Radiation Exposure

Process Requirements

Secondary Wastes and Off Gases

Production Capacity

Process Additives and Auxiliary Materials

Process Versatility and Control

Quality Assurance

Utilities (air, power, water, etc.)

Manpower

Facility Requirements

Noncontact Facilities (remote)

Contact Facilities (hands-on)

Estimated Capital Cost

Total
Factor Weighting Rating Assigned

$\begin{array}{rrrr}\text { Sub } & \text { Total } & & \text { Sub } \\ & 60 & & \\ 5 & & & 45 \\ 5 & & & 25 \\ 12 & & \\ & & \\ 8 & & \\ 15 & & & 40 \\ 5 & & & 90 \\ 5 & & & 30 \\ 5 & & & 40 \\ & & & 45\end{array}$

40

245

5

10

10

10

5

40

250

10

20

10

90

80

80

30

205

15

24

40

35

30

21

40

30

170

10

70

60

10

339

\section{5}

0

0

45


TABLE B.3. Nonconsumable Electrode System Evaluation - Evaluator B

Factor Weighting Rating Assigned

\begin{tabular}{|c|c|}
\hline Sub & Total \\
\hline & 60 \\
\hline $\begin{array}{r}5 \\
5 \\
12\end{array}$ & \\
\hline $\begin{array}{r}8 \\
15 \\
5 \\
5 \\
5\end{array}$ & \\
\hline
\end{tabular}

Material Handling

Consolidation Mode

Maintenance Considerations and Equipment Reliability

Controls and operation

Adaptabulity to Remote Operation

Number of Process Steps

Feasibility for Production

Feed Limitations

40

270

State and Type of Development

Equipment

Type of Development

10

Scale of Development

Development Time Requìred (f rom

initiation of program)

Safaty

40

210

Stability and Atmosphere of Process Steps

10

70

Pyraphoricity, Exotherric, and Explosion Considerations

Personnel Radiation Exposure

20

100

10

40

Process Requitrements

30

210

Secondary Wastes and off Gases

Production Capacity

Process Additives and Auxillary Materials

Process Versatiljty and Control

Quallity As surance

vtilities (air, power, water, etc.)

Hanpower

5
4
5
5
3
3
5

Facility Reguirements

Noncontact Facillities (remote)

Contact Facilities (hands-on)

Estimated Capital Cost

25

40

45

30

18

12

40

30

180

10

70

10

70

10

40

Total

1269 
TABLE 8.4. Nonconsumable Electrode System Evaluation - Evaluator C

Complexity of Process

Material handling

Consolidation Mode

Maintenance Considerations and Equipment Reliablitity

Controls and Operation

Adaptability to Renote Operation

Number of Process Steps

Feasibility for Production

Feed Linitations

State and Type of Develapment

Process

Equipment

Type of Development

Scale of Development.

Development Time Required (f rom initiation of program)

Safety

Stability and Atmosphere of Process Steps

Pyrophoricity, Exothermic, and Explasion Considerations

Personnel Radiation Exposure

Process Reguirements

Secondary Wastes and off boses

Production Capacity

Process Additives and Auxiliary Materials

Process Versatility and Control

Quality Assurance

Utilities (air, power, water, etc.)

Manpower

Facility Requirements

Honcontact Facillities (remote)

Contact Facilities (hands=on)

Estinated Capital Cost

Iotal
Factor Weighting Rating Assigned

Sub $\frac{\text { lotal }}{60} \frac{\text { sub } \frac{\text { lotal }}{390}}{30}$

$\begin{array}{rr}5 & 25 \\ 5 & 50 \\ 12 & 60\end{array}$

$8 \quad B 0$

$15 \quad 60$

525

$5 \quad 40$

$5 \quad 50$

40

290

40

30

260

25

40

50

50

30

15

50

30

230

10

80

10

10

100

50

1410 
TABLE B.5. Honconsumable Electrode System Evaluation - Evaluator D

Factor Heighting Rating Assigned

\begin{tabular}{|c|c|c|}
\hline Sub & lotaI & Sub \\
\hline & 60 & \\
\hline $\begin{array}{r}5 \\
5 \\
12\end{array}$ & & $\begin{array}{l}25 \\
15 \\
60\end{array}$ \\
\hline $\begin{array}{r}8 \\
15 \\
5 \\
5 \\
5\end{array}$ & & $\begin{array}{l}24 \\
45 \\
15 \\
30\end{array}$ \\
\hline
\end{tabular}

Material Handling

Consolidation Mode

15

Maintenance Considerations and Equipment Reliabllity

Controls and Operation

Adaptabillty to Remote Operation

Number of Process Steps

Feasibility for Production

Feed Limitations

40

250

State and Type of Development

24

45

15

30

Process

5

10

Equipmert

10

Type of Development

Scale of Development

Development Time Required (from

10

initiation of program)

Safety

40

150

Stablity and Atmosphere of Process Steps

Pyrophoricity, Exothermic, and Explosion

20

80 Considerations

Personnel Radiation Exposure

10

30

60

60

60

40

Process Reguirements

249

Secondary Wastes and off Gases

Production Capacity

Process Additives and Auxiliary Materials

Process Versatility and Control

Quality Assurance

Ut lities (air, power, water, etc*)

Manpower

Facility Regul rements

Noncontact Facilities (remote)

Contact Faciuluties (hands-on)

Estimated Capital cost

10

10

40

30

30

192

15

32

45

35

15

15

35

30

200

60

100

40

$\underline{\text { Total }}$

1041 


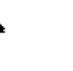

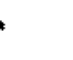


APPENDIX C

PLASMA ARC MELTING 
APPENDIX C

PLASMA ARC MELTING

\section{INTRODUCTION}

The plasma arc melting furnace (Figure C.1) uses an argon plasma arc torch to melt various metals and materials into a molten pool in a water-cooled hearth in an airtight chamber. After the molten pool is formed, a solidified ingot is withdrawn; melting and withdrawal are continued until the desired length is attained.

\section{PRDCESS DESCRIPTION}

The scrap metals or waste materials that will be fed into this melting process will be reduced in size as required for feeding into the hearth from a feed hopper. The scrap metals will be melted by a plasma arc torch positioned as shown in Figure C.I; the plasma arc can be directed and controlled in the $x$, $y$, and $z$ axes. Because the plasma arc melting process is not conducive to the formation of deep molten pools in a water-cooled hearth or crucible, the ingot withdrawal mode is the most practical method.

\section{PROCESS NEEDS AND REQUIREMENTS}

The process will consolidate and solidify the metallic wastes identified in the Process Material Identification section (p. 16). It will be required to produce -105 castings or full canisters ( $2 \mathrm{ft}$ in diameter by $10 \mathrm{ft}$ long) or equivalent in 300 days, and the facility could be operated $24 \mathrm{~h} /$ day. The canisters containing the consolidated process metallics are to be suitable for remote handling and transport and compatible with long-term disposal in a geologic repository. The major process equipment required will essentially be the same as that listed in Appendix A (Table A.1) with some differences in capacity. 


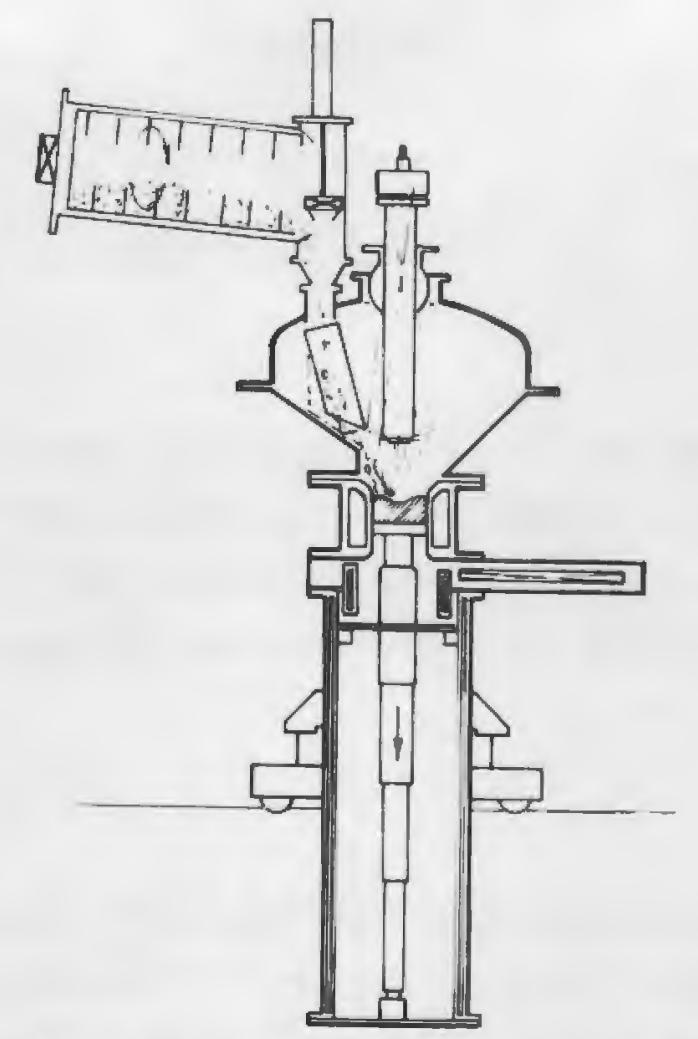

FIGURE C.1. PI asma Arc Furnace

\section{Furnace}

It has been estimated that a plasma furnace similar to the one shown in Figure C.I using the ingot withdrawal mode could process the required annual throughput in 92 days. An ingot containing $\sim 5540 \mathrm{~kg}$ of metal could be produced every $19 \mathrm{~h}$ at a melting rate of $\sim 400 \mathrm{~kg} / \mathrm{h}$. This ingot would fill a 2-ft diameter by 10-ft long canister $\sim 90 \%$ full; 116 canisters would be produced every year. One furnace $(3 \times 5 \times 8 \mathrm{~m}$ high) would handle the projected facility throughput.

Furnace Feed and Canister Handling

The systems required to move process material to and from this furnace are basically the same as those identified in Appendix $A$. 


\section{FACILITY REQUIREMENTS}

The plasma arc melting system is about the same size as the nonconsumable electrode melting system and cauld be up to twice as large as either of the Inductosiag furnaces. Thus, a furnace of this process will require more not cell space than that identified in Appendix $A$.

Qff-Gas System

The estimated flow rates and constituents in the plasma arc melting offgas systen are listed below:

$$
\begin{array}{ll}
\frac{\text { Effluent }}{\text { Gases (a) }} & \frac{\text { Flow Rate }}{90 \mathrm{~m}^{3} / \mathrm{min}} \\
\text { Particulates } & 4 \mathrm{~kg} / \mathrm{h} \\
\hline \text { (a) From Furnace at } 300^{\circ} \mathrm{C} \text { and } 1 \text { atm. } \\
\text { (b) Metal fumes contaminated with radioisotopes, }
\end{array}
$$

Except for the requirement to handle higher flow rates, the off-gas system and its components will be sumilar to those identified for the Inductoslag processes.

Secondary Wastes Requiring Processing

Wastes from the plasma arc melting system that will require processing ape listed below:

\begin{tabular}{ll}
\multicolumn{1}{c}{ Material } & \multicolumn{1}{c}{ Amount } \\
${ } }$ & B00 $\mathrm{e} / \mathrm{min}$ \\
Proces 5 wastes & $10 \mathrm{~kg} / \mathrm{h}$ \\
Ventilation flow & $500 \mathrm{~m}^{3} / \mathrm{min}$
\end{tabular}

Utilities. Services, and Materials

Estimates of the normally required utllities, services, and materials that will be needed for this process are summarized in Table $C_{.} 1$. 
TABLE C.1. Stilities, Services, and Materials

for Plasma Are Melting Process

\begin{tabular}{|c|c|c|c|}
\hline Iten & Capacity & Average Rate & Anount / Year \\
\hline $\begin{array}{l}\text { Electricity } \\
(3500 \mathrm{~A}, 200 \mathrm{~V})\end{array}$ & $700 \mathrm{~kW}$ & $\begin{array}{l}2.2 \mathrm{kWh} / \mathrm{kg} \\
\text { of metal }\end{array}$ & $1,400,000 \mathrm{kWh}$ \\
\hline Water & $1400 \mathrm{~h} / \mathrm{min}$ & $900 \mathrm{e} / \mathrm{min}$ & \\
\hline Air & $750 \mathrm{~m}^{3} / \mathrm{min}$ & $500 \mathrm{~m}^{3} / \mathrm{min}$ & \\
\hline Steam & $15 \mathrm{~kg} / \mathrm{h}$ & $2 \mathrm{~kg} / \mathrm{h}$ & \\
\hline Canisters & $2 \mathrm{ft} \mathrm{dia} \times 10 \mathrm{ft}$ long & & 116 \\
\hline He sources & & & 130 \\
\hline Argon & $0.12 \mathrm{~m}^{3} / \mathrm{kg}$ melted & & $80,000 \mathrm{~m}^{3}$ \\
\hline Hyorautics & $38 \mathrm{a} / \mathrm{min}$ at $140 \mathrm{~kg} / \mathrm{cm}^{2}$ & & \\
\hline
\end{tabular}

\section{ASSESSMENT DISCUSSION}

The numerical ratings assigned to the process by the individual evaluators are presented in Tables 6.2 through $C .5$ (see $D_{*} C .8$ ). The criterla are discussed below. Complexity of Process

The plasma arc furnace is very sumilar in complexity and requirements to the nonconsumable electrode furnace. However, the need to handle both ingots and canisters adds to the complexity of the process.

Haterial tanding. Except for the handing of ingots, the steps and equipment required for this process are the same as thase required for the nanconsumblia electrode process (Appendix B).

Consolidation Mode. The plasma arc melting process can melt a wide range of alloys and netals at high production rates in controlled atmospheres.

Maintenance Considerations and Equipment Reliabllity. The overall reliability of the process equfprent is about the same as that of the nonconsumalie electrade process. The electrodes and their systems are quite compicated, but production applications have shown them to be rellable and fairly long lived. 
Overall maintenance requirements and considerations wlll be similar to those for the nonconsumble electrode process.

Cantrols and 0peration. The controls for and the operation of this furnace wll be comparable to the nanconsumable electrode furnace.

Adaptability to Remote Operation. Various types of plasma arc melting furnaces are being operated for the production of a variety of metal ingots. Recent efforts have been made on the use of plasma furnaces for melting and refining reactive metals and for reducing the volume of radioactive wastes. Hith an adequate development, design, and testing program, it is felt this corrcept could be used in a remote nuclear application.

Number of Process 5teps. Only about 12 process steps are required to fill a canister after the feed material required is loaded in the hoppers. Approximately 17 steps are requiled for the complete processing of a canistar.

Feasibility for Production. One plasma furnace and its supporting system are considered to be adequate and feasible for this application.

Feed Limitations. Limitations on furnace feeds are similar to those for the reference process (Appendix A).

State and Type of Development

Process and/or Equigment. Plasma furnaces larger than the one required for this application are in production operation. Since 1979, the Japanese have been investigating and conducting cold tests on labaratory-scale furnaces to reduce the volume and stabilize noncombustible solid wastes generated at nuclear power plants (Eguchi et al.).

Type and Scale of Development. Developments that will be required prior to actual hot cell operation of a plasma arc furnace include:

- investigate melting a variety of mixtures of metals

- determine off-gas temperatures and the system to adequately process the contaminated off gases and particulates

- develop system(s) for the fully remote monitoring of the electpodes and the molten pool 
- develop and demonstrate systems to feed the furnace and t.0 withdraw the ingots remotely

- demonstrate remote operation and reliability of a largemscale furnace

- identify means to remave and replace the furnace and companents remately

- demonstrate the remote handling of ingots and containers.

Development Time Required. The required design, fabrication, and testing could be done in a period of 36 months.

Safety

Two primary hazards are associated with the plasma arc melting system in addition to the normal concerns regarding the pcocessing of radioactive material:

- A water leak in the crucible during melting of zirconium could result in a steam expansion and a simultaneous reaction of the molten metal and water, forming hydrogen. Explasive mixtures of hydro* gen and air could be released to the surrounding area or cell.

- Finely divided metallic residues that depasit on interior melt chamber surfaces during normal melting (especially zirconium) are a potential fire hazard when the furnace chamber is opened or air is ìntroduced.

Other potential hazards (crucible failure, spills, etcs) are cammon to conven= tional melting of metals. For this ingot process, it has been estimated that the maximum amount of molten metal would be $-300 \mathrm{~kg}$. It.5 temperature could be as high as $1900^{\circ} \mathrm{C}$.

Since all radioactive material w11 be processed in shielded hot cells and devices designed for that purpose, the amount of excess radiation exposure will be a function of equipment maintenance and replacement, process accidents, or equipment fallures. 


\section{Process Requirements}

Secondary Wastes and off Gases. The projected flow rates in this of system will be about three times those in the reference process (Appendix A). Other requirements are essentially the same as for the reference process.

Production Capacity. One furnace is more than adequate to meet the prajected throughput. For the current throughput, the furnace will operate only -92 days/yr: thus, this furnace concept has the capability to handle significant throughput increases.

Process Additives and Auxiliary Materials/Utilities. No special fluxes or chemicals are required for this process. The power and water cooling requirements per unit of metal throughput are less than for the reference process by $-20 \%$. However, this process will require abaut 40 times more gas than the reference process.

Process Yersatility and Contral. Like the reference process, this process will handle and melt a wide range of metals and mixtures that must be controlled to assure ingot integrity.

Manpower. Due to a shorter furnace cycle than the reference process, this process will only need to be run about 92 days/yr.

\section{Facility Reguirements}

The facility required to enclose and support this process is anticipated to be $\mathbf{1 . 1}$ tines bigger than that identified for the reference process or facility: The complexity of the equipment will be similar.

\section{REFERENCES}

Beitel, G, A*, and 0, B. Schlipphacke. 1978. Vacuum Furnace Development Plan. Rockwell Hanfard Operations, Richland, Washington*

Eguchi, 1., et al. Processing of Huclear Hastes by Plasma Arc Melting. Daido Stee] Co., Ltd., Nagoya, Japan. 
TABLE C.2. PIasma Ars System Evaluation - Evaluator A

Complexity of Process

Material Handling

Consolidation Mode

Mäintenance Considerations and

Equipment Religalitity

Controls and Operation

Adaptability to Remote Operation

Number of Process Steps

Feasibility for Production

Feed Limitations

State and Type of Development

Process

Equipment

Type of Developinent

Scale of Development

Developrent Time Required ffrom initiation of programi

5afety

Stability and Atmosphere of Process Steps Pyropharicity, Exothermic, and Explosion Cansiderations

Personnel Radiation Exposure

Process Requirements

Secondary wastes and off Gases

Production Capacity

Process Additives and Auxiliary Materials

Process Versatility and Control

Quality Assurance

Utilities (air, power, water, etc.)

Manpower

Facility Requirements

Noncontact Facilities (remote)

Contact Facilities (hands on)

Estimated Capital Cost

Total
Factor Weighting Rating Assigned

Sub $\frac{\text { Total }}{60} \quad \frac{\text { Sub }}{376}$

25

30

84

32

90

45

40

30

40

220

5

35

50

10

10

10

50

50

35

40

270

10

20

90

120

10

60

30

175

15

32

35

20

15

24

35

30

170

70

60

40 
IABLE C.3. Plasma Arc System Evaluation - Evaluator B

Factor Weighting Rating Assigned Sub Total Sub Total

Lomplexity of Process

60

302

Material Handling

5

Consolidation Mode

Maintenance Considerations and Equipment Reliability

Controls and Operation

Adaptability to Remote Operation

Number of Process 5teps

Feasibility for Production

Feed Limitations

5
12

20

25

72

840

$15 \quad 75$

525

525

520

State and Type of Develogment

40

235

Process

5

Equi iprnent

Type of Development

Scale of Development

10

Development Time Required (from initiation of program)

Safety

40

235

Stability and Atmosphere of Process Steps 10

Pyrophoricity, Exothermic, and Explosion 20 Considerations

Personnel Radiation Exposure 10

Process Requirements

35

50

60

50

40

Secondary Wastes and of $f$ Gases

Production Capacity

Process Additives and Auxiliary Materials

Process Versatility and Control

Quality Assurance

Utilities (air, power, water, etc.)

Manpower 0

Facility Reguirements

Noncontact Facilities (remote) 
IABLE C.4. Plasma Are System Evaluation - Evaluator $C$

Factor Heighting Rating Assigned ईub Total Sub Total

Complexity of Process

60

365

Meterial Handling

Consollidation Mode

Maintenance Considerations and Equipment Reliability

Controls and Operation

Adaptability to Rernote Operation

Number of Process Steps

Feasibility for Production

Feed Limit tations

\section{5}

5

12

$\begin{array}{rr}8 & 80 \\ 15 & 60 \\ 5 & 25 \\ 5 & 40 \\ 5 & 25\end{array}$

State and Type of Development

Process

Equipment

Type of Development

Scale of Development

Development Time Required (from initiation of program)

Safety

Stability and Atmosphere of Process Steps 10 Pyrophorictity, Exothertic, and Explosion 20 Considerations

Personnel Radiation Exposise

10

40

310

5

10

10

10

5

40

240

90

100

50

Process Requirements

30

245

Secondary Wastes and of $f$ Gases

Production Capacity

Process Additives and Auxiliary Materials

Process Versatility and Control

Quality Assurance

Jtilities (atr, power, water, etc.)

Manpower

5

4

5

5

3

3

5

Facllity Requirenents

Noncontact Facillties (remote)

Contact Facilities (hands-on)

Estimated Capital cost

10

10

10
25

50

60

0

5

25

40

80

10

80

40
25

40

50

50

15

15

50

30

230

80

100

50

Total 
IABLE C*5. Plasma Arc System Evaluation - Evaluator D

Complexity of Process

Material Handling

Consolidation Mode

Maintenance Consterations

Equipment and Reliability

Controls and Operation

Adaptabillty to Remote Operation

Number of Process 5teps

Feasiblity for Production

Feed Limitations

State and Type of Develogment

Process

Equipment

Type of Development

Scale of Development

Development Time Required (from

initiation of program!

Safety

Stability and Atmosphere of Process Steps 10

Pyrophoricity, Exothermic, and Explasion 20 Considerations

Personnel Radiation Exposure

Process Requirements

Secondary Hastes and of $\mathrm{f}$ Gases

Production Capacity

Process Additives and Auxiliary Materials

Process Versatility and Contral

Quality As surance

Utilities (air, power, water, etc.)

Manpower

Facility Reguirements

Noncontact Facilities (remote)

Contact Facilities (hands-on)

Estimated Capital Cost
Factor Weighting

Sub

\section{5}

12

8

15

5

5

5

40

5

10

10

10

5
Rating Assigned Sub Total

239

20

20

60

24

45

20

30

20

210

25

50

50

50

35

40

150

80

40

30

30

184

15

32

40

30

12

15

40

30

200

10

10

10
60

100

40

Total 
- 
APPENDIX D

ELECTROSLAG NELTING 


\section{APPENDIX D}

\section{ELECTROSLAG MELTING}

\section{INTRODUCTION}

A process flow diagram of an Electroslag melting system for the solidification of plutonium-contaminated metallic wastes is shown in Figure $D_{*} 1$ (Ochiai et a1. 1982). Electroslag process metal is melted in molten slag held in a joule-heated furnace. The furnace operates on the principle that the molten solution will conduct electricuty, therefore making it possible to pass alternating current through electrodes on each side of the furnace to generate heat in the slag/metal mixture.

\section{PROCESS DESCRIPTION}

The Japanese are using water-cooled copper molds, and nonconsumable tungsten electrodes have been used. A mixture of $\mathrm{CaO} / \mathrm{A} /{ }_{2} \mathrm{O}_{3} / \mathrm{B}_{2} \mathrm{O}_{3}$ has been found to be a satisfactory slag material for the waste presently melted by the lapanese. However, this slag would not be appropriate for melting zirconium because the zirconium would reduce the oxide slag. Calcium fluoride or some similar nonoxide slag would have to be used. The stool-arc method has been determined to be the best for the inftial slag melting.

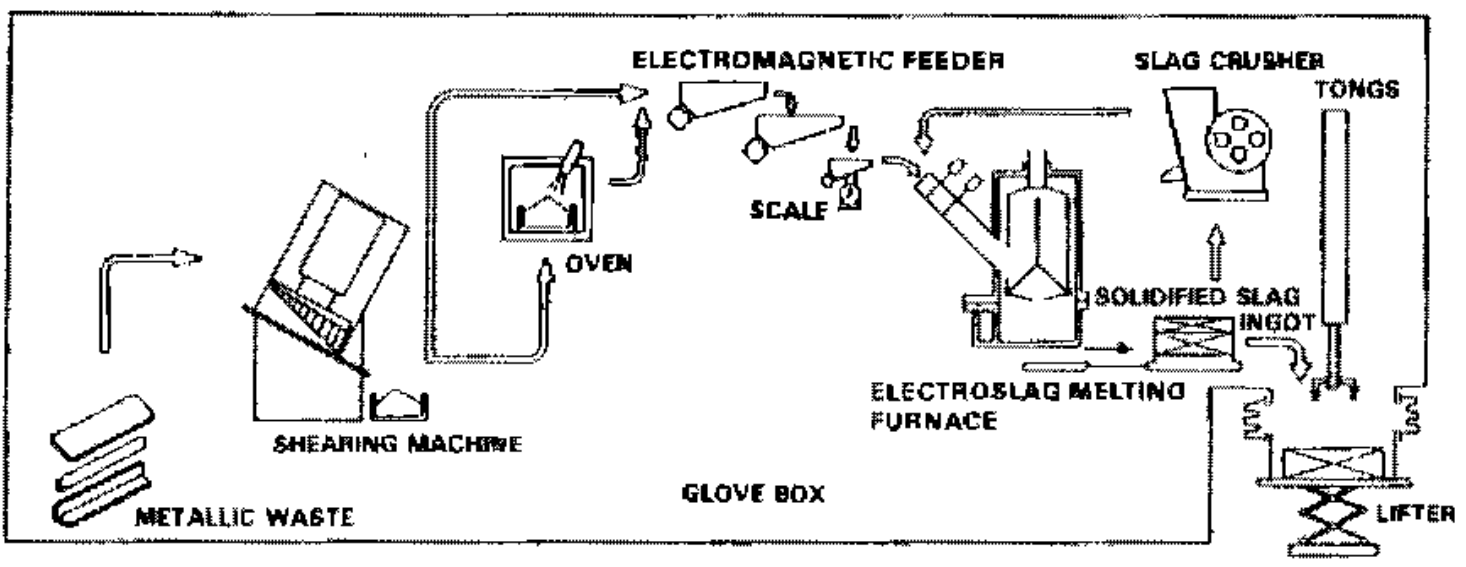

FIGURE 0.1. Process Flon Diagram of Electraslag Meltịng Process 
Scrap netals to be fed into this process will have been reduced to a size that can be handled by the furnace feed mechanisms. The scrap metal is fed into the furnace and deposited by controlited means on top of the molten slag or Inixture of retal/slag as shown in Figure D.2 (Dchiai et a . 1982). After melt. ing, the metal gradually solidifies in the fower portion of the furnace mold.

An inert gas is required in the furnace to prevent oxidation of the electrodes, and the pressure in the furnace is kept at $w / 3$ atmosphere. To permit the removal of the solidified ingot, the mold is divided into halves. Thus, the ingot and the solidified slag can be moved froll the furnace and separated. The slag is erushed and recycled, and the ingot is placed in a contatner or canister.

\section{PROCESS NEEUS AND REQUIREMENTS}

The process will consolidate and solidy the metallic wastes identified in the Process Material Identification section (p. 16). It will be required to

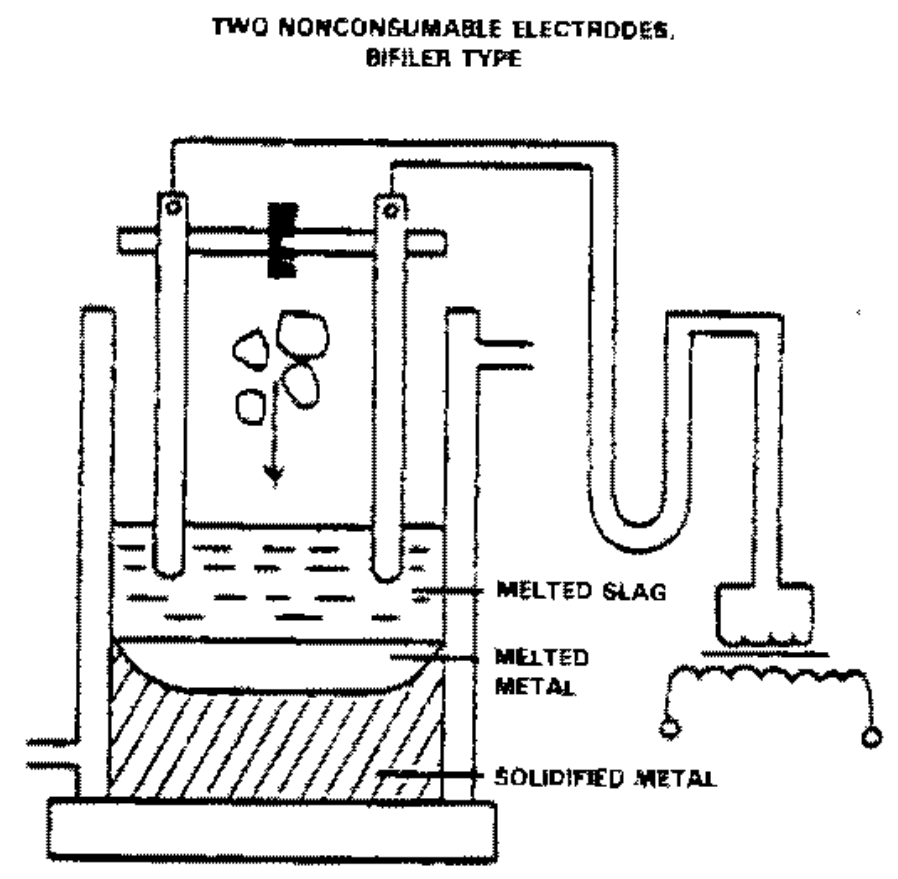

FIECES OF NETAL AFE DEPOSTTED BETWEEN THE NONCONGUNAELE TUNGSTEN ELECTTDDES AND MEITED

FlGURE D.2. Electroslag Melting Furrace 
produce $~ 105$ ingots (2 $\mathrm{ft}$ in diameter by $10 \mathrm{ft}$ long) or equivalent in 300 days, and the facility could be operated $24 \mathrm{~h} / \mathrm{day}$. The canisters containing the consolidated process metallics are to be suitable for remote handiing and transport and compatible with lang-term disposal in a geologic repasitory. The major remote process equipment that will be required is listed in Table 0.1 .

TABLE D.1. Major Remote Equipment for Electroslag Melting Process

\begin{tabular}{|c|c|}
\hline Equipment & Capacity \\
\hline Crane hoist & 60 tons \\
\hline Storage crane hoist & 10 tons \\
\hline Drum dumper crane and hoist & 10 tons \\
\hline Drum dumper & $-\infty$ \\
\hline Charge hopper & $\ldots$ \\
\hline Feeder & $\ldots$ \\
\hline Melter & .. \\
\hline Ingot/canister handing systern & 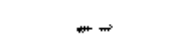 \\
\hline Goier & $\ldots$ \\
\hline slag recycle system & $m$ \\
\hline Canister welder & $-\ldots$ \\
\hline Canister leak test station & $\cdots$ \\
\hline Canister decontamination station & $\ldots$ \\
\hline Cell cranes and manipulators & -- \\
\hline Quench tower & -- \\
\hline Venturi scrubber & - \\
\hline De-entrainer & -.. \\
\hline Stearm vacuum jet & -- \\
\hline Spray condenser & $\cdots$ \\
\hline Scrubber recycle tank & .. \\
\hline Scrubber solution cooler & $=$ \\
\hline of $\mathrm{f}$-gas heater & - \\
\hline Off-gas primary filters & $-\cdots$ \\
\hline Ruthenium absorbers & -- \\
\hline Off $f_{\text {mgas }}$ reheaters & $-\cdots$ \\
\hline Final filters & -- \\
\hline off mgas blawers & $-\infty$ \\
\hline Scrubber solution air lift pot & -. \\
\hline
\end{tabular}




\section{Furnace Feed}

Provisions and equipment similar to those shown in Figure A.5 will be required to handle and move the process feed material to the furrace. A charge hopper with the capacity to hold up to $1 \mathrm{day}^{*} \mathrm{~s}$ throughput (150 $\mathrm{ft}^{3}$ and $4500 \mathrm{~kg}$ ) will be required above and close to the furmace. It is connected to the center cavity of the furnace with a system that will move the feed material $(6 \times 6 \times$ 5 in. or less) into the furnace on a demand and controlled basis without voiding the atmospheric control of the furnace. The slag feed system is alsa conm nected to the upper portion of the furnace. The system introduces the desired slag mixture into the furnace mold on a controlled and fast-feed basis. It is supplied and fed with new or recycled slag material.

\section{Furnace}

An Electroslag melting furmace similar to the one shown in Figure D,3 (Ochiat et a . 1982) will be required. Six 900-kg ingots would fill a 2 mt diameter by $10-f t$ long canister $-88 \%$ full. It has been estimated that these ingots could be produced in $45 \mathrm{~h}$; 119 canisters would be required for the annual facility throsghput. A furnace $-8 \times 12 \times 18 \mathrm{ft}$ high would be required.

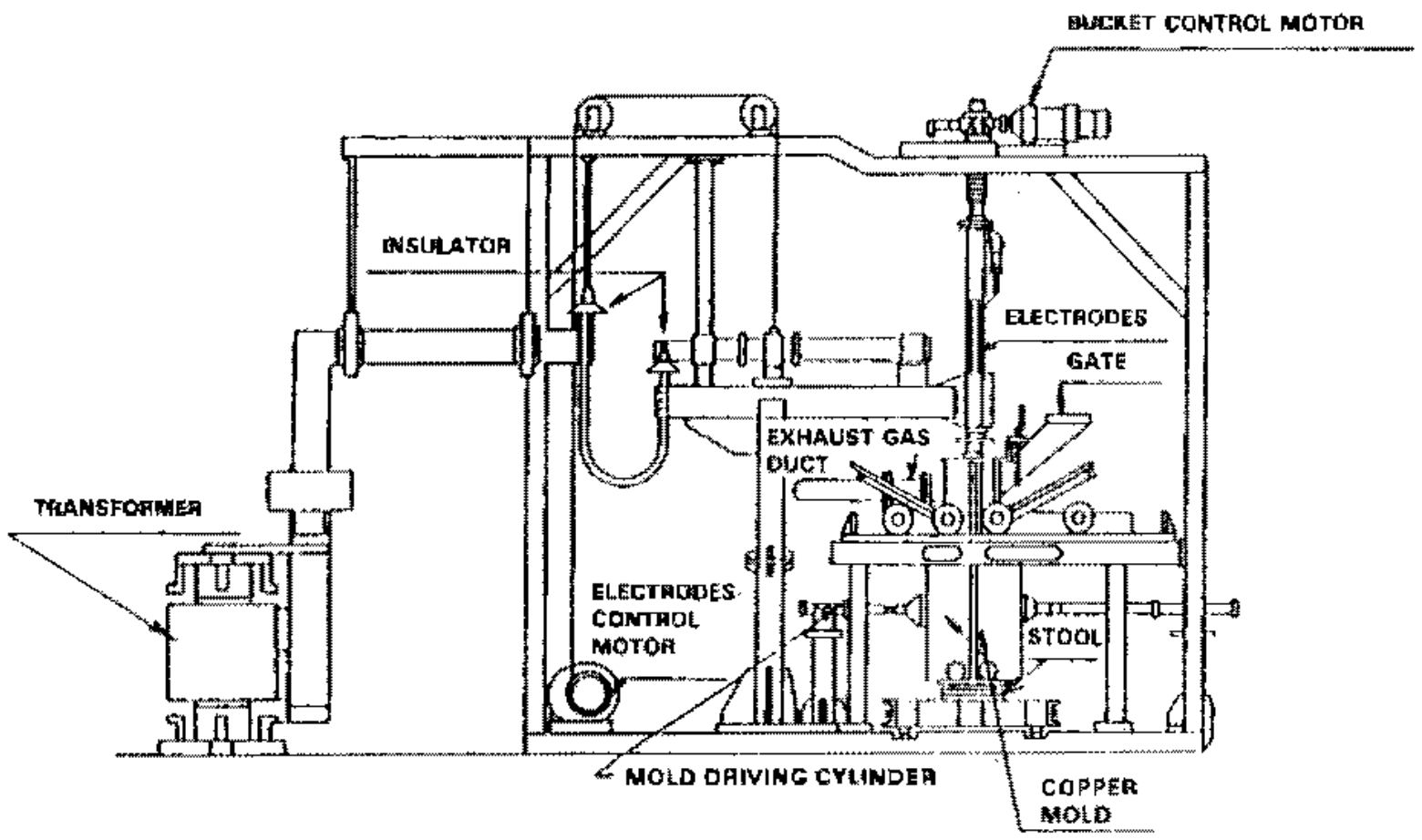

FIGURE D. 3. Electroslag relting Furnáce 
Ingot and Canister Handling

The system required to close and handle canisters after they are filled will be the same as that identified in Appendix A for the processing of canisters. Recycling slag, handing ingots, and inserting ingots into a canlster will require more equipment than identified in Appendix $A$.

\section{FACILITY REQUIREMENTS}

Since the projected size of an Electroslag furnace is similar to that estimated for an Inductoslag furnace, it is assumed that with some reconfiguration of the facility this furnace would fit into the basic facility arrange ments shown in Figures $A, 5, A .7$, and $A .8$. Due to the need to recycle flux and to handle and canisterize a number of small ingots, it has been estimated that this process would need a total hot cell volume $\sim 1.25$ times larger than that identified for the handling of ingots and canisters in Appendix $A$. Off-Gas System

The estimated flow rates and constituents in the Electroslag melting offgas system are listed below:

$\begin{array}{ll}\frac{\text { Effluent }}{\text { Gases(a) }} & \frac{\text { Flow Rate }}{90 \mathrm{~m}^{3} / \mathrm{mt} \pi} \\ \text { Particulates }(\mathrm{b}, \mathrm{C}) & 4,0 \mathrm{~kg} / \mathrm{h}\end{array}$

(a) From furnace at $600^{\circ} \mathrm{C}$ and $1 / 3 \mathrm{~atm}$.

(b) Metal fumes contaminated with radioisotopes.

(c) Also includes $\mathrm{CaO}, \mathrm{Al}_{2} \mathrm{O}_{3}, \mathrm{~B}_{2} \mathrm{O}_{3}$, and $\mathrm{w}_{3}$ particles $\left(\sim 0.42 \mathrm{~g} / \mathrm{Nm}^{3}\right)$.

Except for the requirement to handle higher flow rates, the system and its components will be similar to those identified for the Inductoslag processes.

Secondary Wastes Regulring Processing

Vastes from the Electroslag melting system that will require processing are listed below: 


$\begin{array}{lll}\frac{\text { Material }}{\text { Nonradioactive cooling water }} & & \frac{\text { Anount }}{1000 \mathrm{\ell} / \mathrm{min}} \\ \text { Process wastes } & & 10 \mathrm{~kg} / \mathrm{h} \\ \text { Ventilation flow } & & 600 \mathrm{~m}^{3} / \mathrm{min}\end{array}$

Utilities, Services, and Materials

Estimates of the normally required utilities, services, and materials that will be required for the Electroslag melting system are indicated in Table D.2.

ASSESSMENT DISCUSSION

The numerical ratings assigned to the process by the individual evaluators are shown in Tables D.3 through 0.6 (see p. D.11). The criteria are discussed below.

Complexity of Process

Oue to the need to handle a large number of ingots and insert several into each canister, the material handling equipment will be very involved. Separating and recycling the slag also adds to the process complexity. Furnace operational and control requirements are more complex than those of the reference Inductoslag furnace.

TABLE D.2. Utilities, Services, and Materials for Electroslag Melting Process

\begin{tabular}{|c|c|c|c|c|}
\hline \multicolumn{2}{|c|}{ Item } & Capacity & Average Rate & Anount/Year \\
\hline \multicolumn{2}{|c|}{ Electricity } & $1200 \mathrm{kVA}$ & $960 \mathrm{~kW}$ & $642,000 \mathrm{~kW} / \mathrm{h}$ \\
\hline \multicolumn{2}{|l|}{ Water } & $1800 \ell / \mathrm{min}$ & $1200 \mathrm{l} / \mathrm{min}$ & \\
\hline \multicolumn{2}{|l|}{ Air } & $900 \mathrm{~m}^{3 / m i n}$ & $600 \mathrm{~m}^{3} / \mathrm{min}$ & \\
\hline \multicolumn{2}{|l|}{ Steam } & $15 \mathrm{~kg} / \mathrm{h}$ & $2 \mathrm{~kg} / \mathrm{h}$ & \\
\hline \multirow[t]{3}{*}{ Slag: } & $\mathrm{Ca}_{2}{ }^{\mathrm{O}}$ & & & $6100 \mathrm{~kg}$ \\
\hline & $\mathrm{Al}_{2} \mathrm{O}_{3}$ & & & $6200 \mathrm{~kg}$ \\
\hline & $\mathrm{B}_{2} \mathrm{O}_{3}$ & & & $650 \mathrm{~kg}$ \\
\hline \multicolumn{2}{|c|}{ Canisters } & $2 \mathrm{ft}$ dia $\times 10 \mathrm{ft}$ long & & 118 \\
\hline \multicolumn{2}{|c|}{ He sources } & & & 125 \\
\hline \multicolumn{2}{|c|}{ Argon } & & & $2300 \mathrm{~m} 3$ \\
\hline
\end{tabular}


Material Handing. The steps and equipment required for this process are more complex than those required for the reference process.

Consolldation Mode. The Electroslag melting process utifizes the jouleheating concept were electrical current passes through the slag/metal mixture located between two nonconsumable electrodes.

Maintenance Considerations and Equipment Reliability. The equipment required for this melting system is considered to be about as reliable as that of the reference system. The ronconsumable tungsten electrodes and their systems and life expectancy are more involved and shorter lived than comparable parts of the reference process, but the mold or crucible is not as vulnerable. Removing the ingots from the furnace, recycling slag, and filling the canisters with several ingots will require more equipment and introduce more maintenance concerns than the reference pracess.

Controls and 0peration. The controls for and the operation of this process are consldered to be more camplex than those of the reference process.

Adaptability to Renote Operations. A pilot plant-scale furnace has been designed for operation in an a-tight glove box (ochial et al. 1982). Similar larger furnaces with consumable electrodes are being operated in various industries. After an adequate development, design, and testing program, it is felt this cancept could be operated and matritained under fully renote nuclear applications.

Number of Prucess Steps. Approximately 43 process steps are required to flll one canister with ingots after the required feed material is loaded in the hoppers. The number of operations involved in the complete processing of one canister is less for this process than that required to process an equivalent amount of material in the reference process (48 versus 64 ).

Feasibility for Production. One Electroslag furnace and supporting system are deemed adequate and feasible for this application.

Feed Limitations. This furrace would have fewer feed limitations than the reference furnace. 
State and Type of Development

Process and/or Equipment. Similar larger furnaces with consumabie electrodes are in production operation in various industries. As noted above, a phot-scale furnace has been designed for operation in a glove box.

Type and 5cale of Development, Cevelopments that will be required prior to actual hot cell operation of an Electroslag furnace include:

- investigate the capability of melting a variety of mixtures of metals including zircanium and determine what fluxes are required

- determine off-gas temperatures and the systen to adequately process the contamitrated off gases and particulates

- develop systems to remotely monitor furnace operation

- develop and demonstrate systens to feed the furnace remotely

- demonstrate remote operation and reliabllity of large-scale furnace

- identify means to remove and replace the furnace and components remotely

- demanstrate the remote handing of ingots and containers.

Develogment Tine Required. The required design, fabrication, and testing could be done in a period of 36 months.

Safety

Two prinary hazards are associated with the Electroslag melting syster in adation to the normal concerns regarding the processing of radioactive materiats:

- A water leak in the crucible ducing melting of zirconiun could result in a steam expansion and a simultaneous reaction of the molten metal and water, forming hydrogen. Explosive nixtures of hydrogen and air could be released to the surrounding area or cell.

- Finely divided metallic residues that deposit on the interior fielt chamber surfaces during normal melting (especially zirconium) are a potential fire hazard when the furnace chamber is opened or air is ịntroduced. 
Other potential hazards (crucible failure, spills, etc, are common to conventional melting of metals. For this ingot process, it has been estimated that the maximum amount of molten metal at any time would be $-300 \mathrm{~kg}$. Its temperature could be as high as $1900^{\circ} \mathrm{C}$.

Since all radioactive material will be processed in shielded hot cells and devices designed for that purpose, the anount of excess radiation exposure would be a function of equipment maintenance and replacement, process accident 5 , or equipment failures.

Process Requirements

Secondary wastes and off Gases. The projected fum rates in this off-gas systen will be about three times those of the reference process. Other requirements are essentially the same as those of the reference process.

Production Capacity, One furnace hould appear to be adequate for the projected throughput; however, it would not be capable of handing any significant increases.

Process Additives and Auxiliary Materials/Utilities. Additional chentcals and fluxes are required for this process. The gas, power, and cooling water requirements are similar to those of the reference process.

Process Versatility and Control. This process will melt various metals with a wide melting range and/or mixtures. Within the limits imposed by an off-gas systeri, this process can be fed sone combustible and nonmetallic materials. In addition, the type and amount of nonmetallic feed faterials would be limited by the need to assure the integrtty of the ingot until it can be placed in a canister. Ascertaining that an ingot is in one plece and sultable for loading into a canister will be a definite quality control checkpoint for this process.

Manpower. Due to a longer furnace cycle than the reference process; more operating manpower will be required. The process will be run ma68 days/yr. 
Facility Requirements

The fachity required to enclose and support this process will be somewhat larger than that identified for the reference process or facility. Equipment complexity will be sinilar.

\section{REFERENCES}

Ochial, A*, et al. 1982. "Treatment of Plutoniumm Contaminated Metallic Wastes by Electrosiag Mel ting Method." Presented at International 5ymposium on the Conditioning of Radioactive kastes for Storage and Disposal, June 1982; Utrecht: The Netherlands. 
TABLE D.3. Electroslag System Evaluation - Evaluatar A

Complexity of Process

Materlal Handling

Consolluation Mode

Maintenance Considerations and Equipment Reliability

Controls and Operatian

Adaptability to Remote Operation

Number of Process Steps

Feasibility for Production

Feed Limitations

State and Type of Development

Process

Equipment

Type of Levelopment:

Scale of Development

Gevelopment Time Required (from

initiation of program)

Safety

Stability and Atmosphere of Process Steps

Pyrophoricity, Exotherinic, and Explosion Considerations

Personnel Radiation Exposure

Process Requirements

Secondary hastes and off Gases

Production Capacity

Process Additives and Auxillary Materials

Process Versatility and control

Quality Assurance

Utilities (air, power, water, etc.)

Manpower

Facility Requirenents

Noncontact Facillties (remote)

Contact Facilities (hands -on)

Estimated Capital Cost

Total
Factor hieighting Rating Assigned

$\begin{array}{ccc}\text { Sub } & \frac{\text { Total }}{50} \text { Sub } \\ & & \\ 5 & & 10 \\ 5 & & 35 \\ 12 & & 48 \\ 8 & & \\ 15 & & 48 \\ 5 & & 75 \\ 5 & & 35 \\ 5 & & 45 \\ & & 35\end{array}$

40

240

35

70

50

50

25

40

240

I0

20

10

130

15

20

30

20

15

15

15

30

80

80

50

50

1121 
TABLE D.4. Electroslag System Evaluation - Evaluator B̂

\begin{tabular}{|c|c|c|c|c|}
\hline & Fact & hting & Rati & igned \\
\hline & Sub & Tatal & Sub & Tota! \\
\hline Complexity of Process & & 60 & & 260 \\
\hline Material Handing & 5 & & 15 & \\
\hline Consolidation Made & 5 & & 20 & \\
\hline $\begin{array}{l}\text { Maintenance Considerations and Equipment } \\
\text { Reliability }\end{array}$ & 12 & & 60 & \\
\hline Controls and Operation & 8 & & 40 & \\
\hline Adaptability to Remote Operation & 15 & & 60 & \\
\hline Number of Process Steps & 5 & & 20 & \\
\hline Feasibility for Production & 5 & & 25 & \\
\hline Feed Limitations & 5 & & 20 & \\
\hline State and Type of Development & & 40 & & 230 \\
\hline Process & 5 & & 30 & \\
\hline Equ f prisent & 10 & & 50 & \\
\hline Type of Development & 10 & & 60 & \\
\hline Scale of Development & 10 & & 50 & \\
\hline Development Time Required (from & 5 & & 40 & \\
\hline Safety & & 40 & & 220 \\
\hline Stability and Atmosphere of Process Steps & 10 & & 70 & \\
\hline $\begin{array}{l}\text { Pyrophoricity, Exathermic, and Explosion } \\
\text { Considerations }\end{array}$ & 20 & & 100 & \\
\hline Personnel Radiation Exposure & 10 & & 50 & \\
\hline Process Requirements & & 30 & & 134 \\
\hline Secondary Wastes and off Gases & 5 & & 15 & \\
\hline Production Capacity & 4 & & 20 & \\
\hline Process Additives and Auxiliary Materials & 5 & & 30 & \\
\hline Process Versatility and Control & 5 & & 20 & \\
\hline Quality Assurance & 3 & & 12 & \\
\hline Utilities (atr, power, water, etc.) & 3 & & 12 & \\
\hline Manpower & 5 & & 25 & \\
\hline Facility Reguirements & & 30 & & 190 \\
\hline Noncontact Facilities (remote) & 10 & & 70 & \\
\hline Contact Fachlities (harnds-on) & 10 & & 70 & \\
\hline Estimated Capital Cost & 10 & & 50 & \\
\hline Total & & & & 1034 \\
\hline
\end{tabular}


TABLE 0.5. Electroslag System Evaluation - Evaluator C

Complexity of Process

Material Handling

Consolidation Mode

Mainterance Considerations and Equínment. Reliability

Controls and Operation

Adaptability to Remote Operation

Number of Process 5teps

Feasibllity for Production

Feed Linitations

State and Type of Development

Process

Equipinent

Type of Levelopment

Scale of Development

Uevefopment Time Required (from

initiation of program)

Safety

Stability and Atmosphere of Process Sreps

Pyrophoricity, Exothermic, and Explosion considerations

Personnel Radiation Exposure

Process Requil rements

Secondary wastes and of $f$ bases

Production Capacity

Process Additives and Auxiliary Materials

Process Versatility and Control

Quality Assurance

It flities (ajr, power, water, etc.)

Manpower

Facility Requirements

Noncontact Facilities (remote)

Contact Facilities (hands mon)

Estimated Capital Cost

Total
Factor Weighting Rating Assigned

$\begin{array}{rrr}\text { \$ub } & \frac{\text { Total }}{60} & \text { Sub } \\ & 60 & \\ 5 & & 5 \\ 5 & & \\ 12 & & 60 \\ 8 & & \\ 15 & & 48 \\ 5 & & 30 \\ 5 & & 5 \\ 5 & & 30 \\ & & 25\end{array}$

40

145

20

20

50

30

25

40

240

10

90

90

50

30

150

5

5

20

50

40

15

15

30

230

10

80

100

10

50 
TABLE D.6. Electroslag 5ystem Evaluation - Evaluator D

Complexity of Process

Material handling

Consolidation Mode

Maintenance Considerations and Equipment Reltublitity

Controls and operation

Adaptability to Renote Operation

Number of Process Steps

Feasibility for Production

Feed Limitations

State and Type of Development

Process

Equífoment

Type of Development

Scale of Development

Development Time Required (from

initiation of program)

Safety

Stability and Atmosphere of Process Steps

Pyrophoricity, Exothermic, and Explosion Considerations

Personnel Radiation Exposure

Process Requirements

Secondary Wastes and off Gases

Production Capacity

Process Additives and Auxiliary Materials

Process Versatility and Control

Quality Assurance

Utllities (air, power, water, etc.)

Manpower

Fachllivy Requir renents

Noncontact Facilities (remote)

Contact Facilities (hands-on)

Estimated Capital cost

Total
Factor Weighting Rating Assigned

\begin{tabular}{|c|c|}
\hline Sub & Total \\
\hline & 60 \\
\hline $\begin{array}{r}5 \\
5 \\
12\end{array}$ & \\
\hline $\begin{array}{r}8 \\
15 \\
5 \\
5 \\
5\end{array}$ & \\
\hline
\end{tabular}

40

225

$5 \quad 30$

$10-60$

$10 \quad 50$

$10 \quad 50$

535

40

140

10

20

10

147

30

15

28

35

30

9

15

15

30

210

10

70

100

40

190

6

0

5

60
0
0
5

80

20

10

10

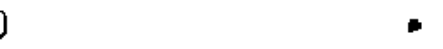




\section{APPENDIX E}

VACUUM CORELESS INDUCTION MELTING 


\section{VACUUM CORELESS INDUCTION MELTING}

\section{INTROOUCTION}

In the vacuum induction melting process, metals are melted by induction heating under a protective atmosphere and/or a vacuum. There are basically two types of induction furnaces: the core or channel-type furnace (Figure E.1) and the coreless or crucible furnace (Figure E.2) (Kotzin 1972). The highfrequency induction furnaces operate on the principle of an air-cored transformer with the charge representing the short-circuited secondary winding of a single-turn coil. High-frequency power is used to decrease the current penetration and increase the heating effect. Although both furnaces induce current into the metal to be melted, the number of coil designs, power sources, and frequencies used with these furnaces have shown tbat one type will work better than the other in many given melting situations.

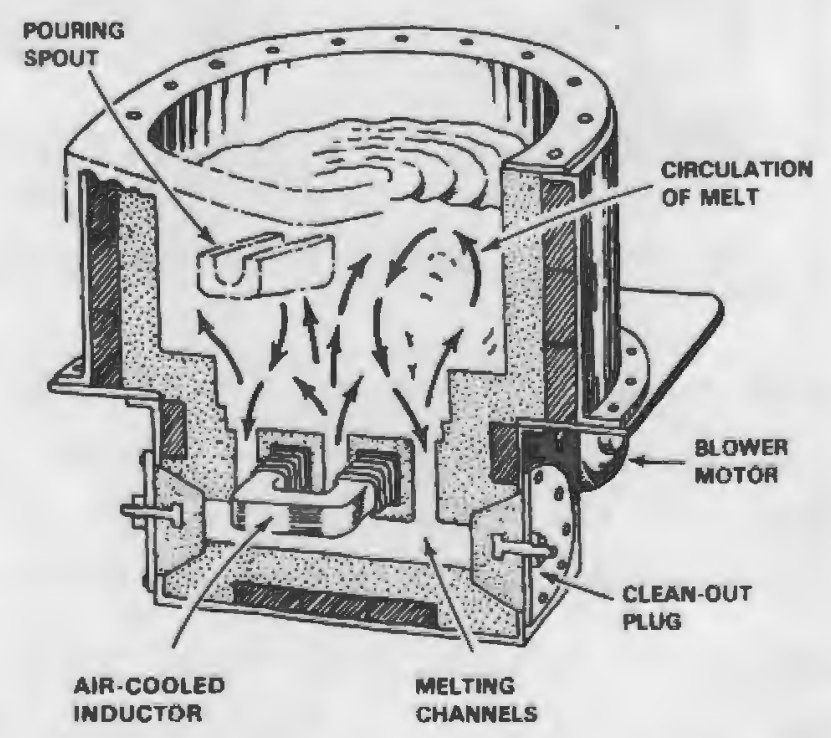

FIGURE E.1. Cored Induction Furnace 


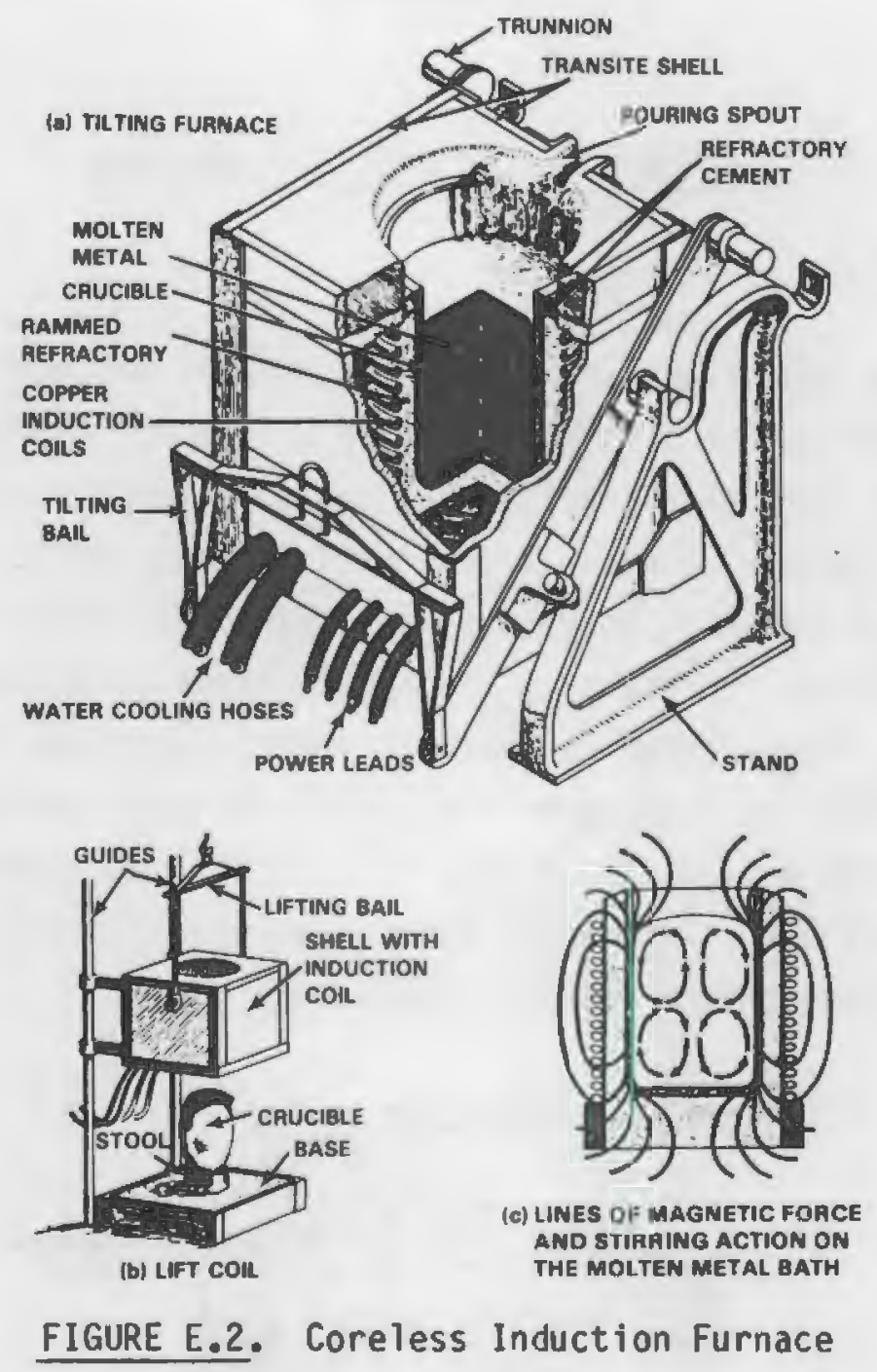

The coreless high-frequency furnace will be the only type considered for this application. It can be started with a cold charge, poured empty, and has a wider range capacity than the channel-type furnace. The coreless-type furnace imposes no theoretical limitation on capacity or $\mathrm{kW}$ rating.

Induction furnaces with melting capacities of -500 to $20001 \mathrm{~b}$ and larger normally use a rammed oxide refractory as the crucible. The reference metallic wastes include Zircaloy hulls that cannot be melted in an oxide refractory crucible because of the intense reactivity between molten zirconium and oxide refractories. However, past work has shown that Zircalay hulls form a low melting eutectic mixture of zirconium with iron, nickel, and chromium; and they 
can be melted in a graphite crucible (Nelson and Griggs 1976). A metal/crucible reaction still occurs, but the crucibles can be reused for an undetermined number of heats. The low melting eutectics occur at the approximate composition of the fuel bundle residues.

Other work (Westerman 1962) has shown that pure zirconium can be melted in graphite crucibles and held for 20 min at $-2000^{\circ} \mathrm{C}$ with a carbon pickup of 0.41 \pm 0.05 wt\%. Since this is the approximate saturation level of carbon in zirconium, it follows that multiple heats could be made and poured from a graphite crucible before the crucible would have to be replaced. The melting of stainless steel has shown that multiple heats can be made in clay/graphite crucibles without undue erosion or wear of the crucible. Thus, graphite crucibles would be used to melt Zircaloy hulls and/or eutectic mixtures of Zircaloy plus iron, nickel, and chrome. Clay/graphite crucibles would be used to melt stainless steel and nonferrous metals or alloys like copper and aluminum. The core or channel-type furnace is only applicable for the tilt-and-pour method of casting molten metal. The coreless or crucible furnace would be applicable for either pouring method. The bottom pour method is illustrated in Figure E.3; the tiltand-pour method, in Figure E.4. In the bottom pour mode, furnace components such as the induction coil and the crucible will be replaceable as modules (Figure E.5).

PROCESS NEEDS AND REQUIREMENTS

With a melting rate of $\sim 1400 \mathrm{~kg} / \mathrm{h}$ and a maximum molten pool of metal of $1400 \mathrm{~kg}$, this casting mode would require 71 days to process $642,210 \mathrm{~kg}$ of metallic waste from a 1500-MTU/yr processing plant. About 118 canisters 90\% full would be required. It is estimated that four heats would be made per crucible liner or one liner per canister. Assuming that the secondary waste liner weighs $-68 \mathrm{~kg}$ and an incineration reduction factor of at least $10: 1$, the cruci. ble waste would be $900 \mathrm{~kg} / \mathrm{yr}$.

\section{Furnace Feed and Canister Handling}

The systems required to move process material to and from the vacuum melting furnace are basically the same as those identified in Appendix A. Process material could be fed to the top of the furnace using 55-gal barrels. Several 


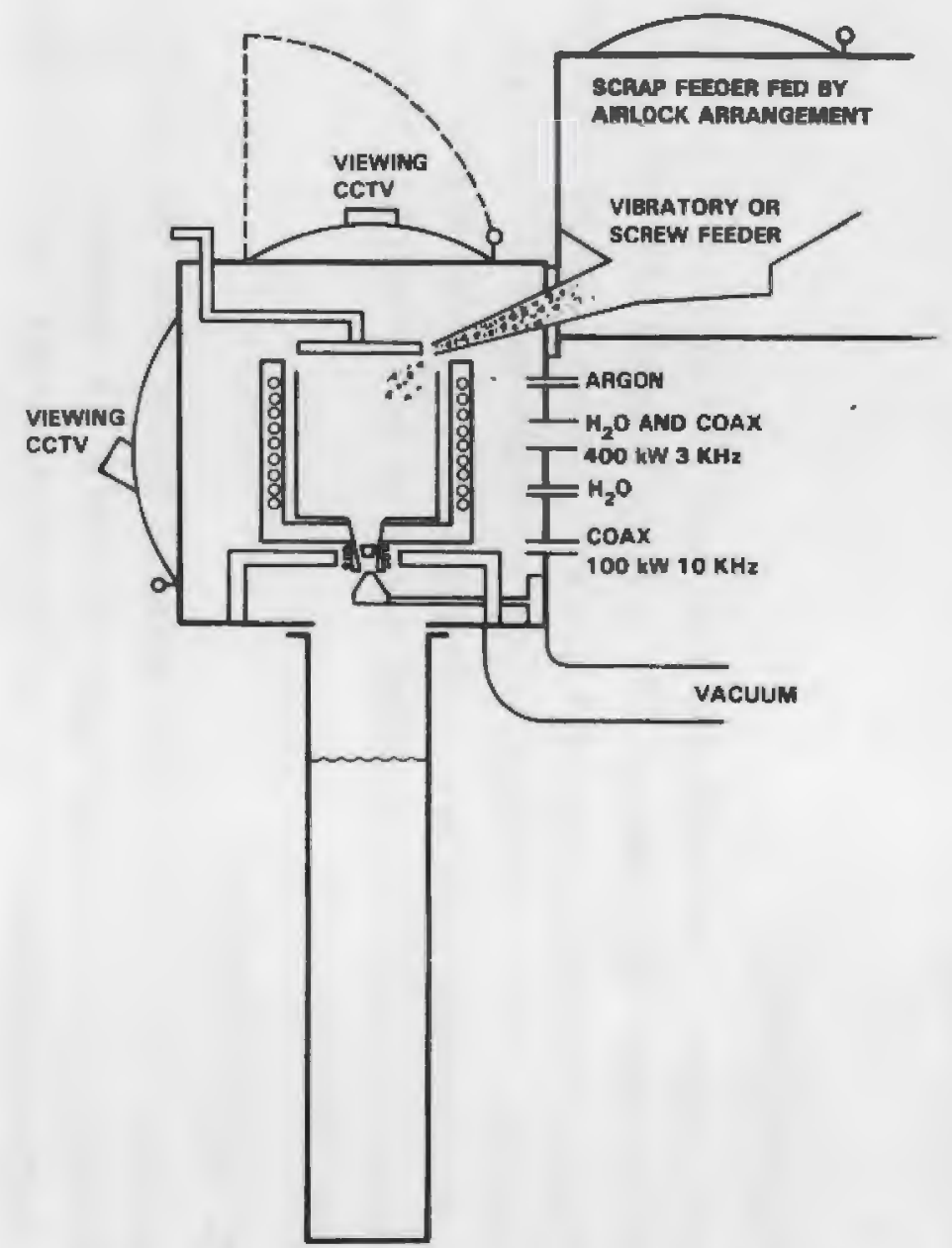

FIGURE E.3. Bottom Pour Stationary Crucible for Vacuum Induction Melting Process

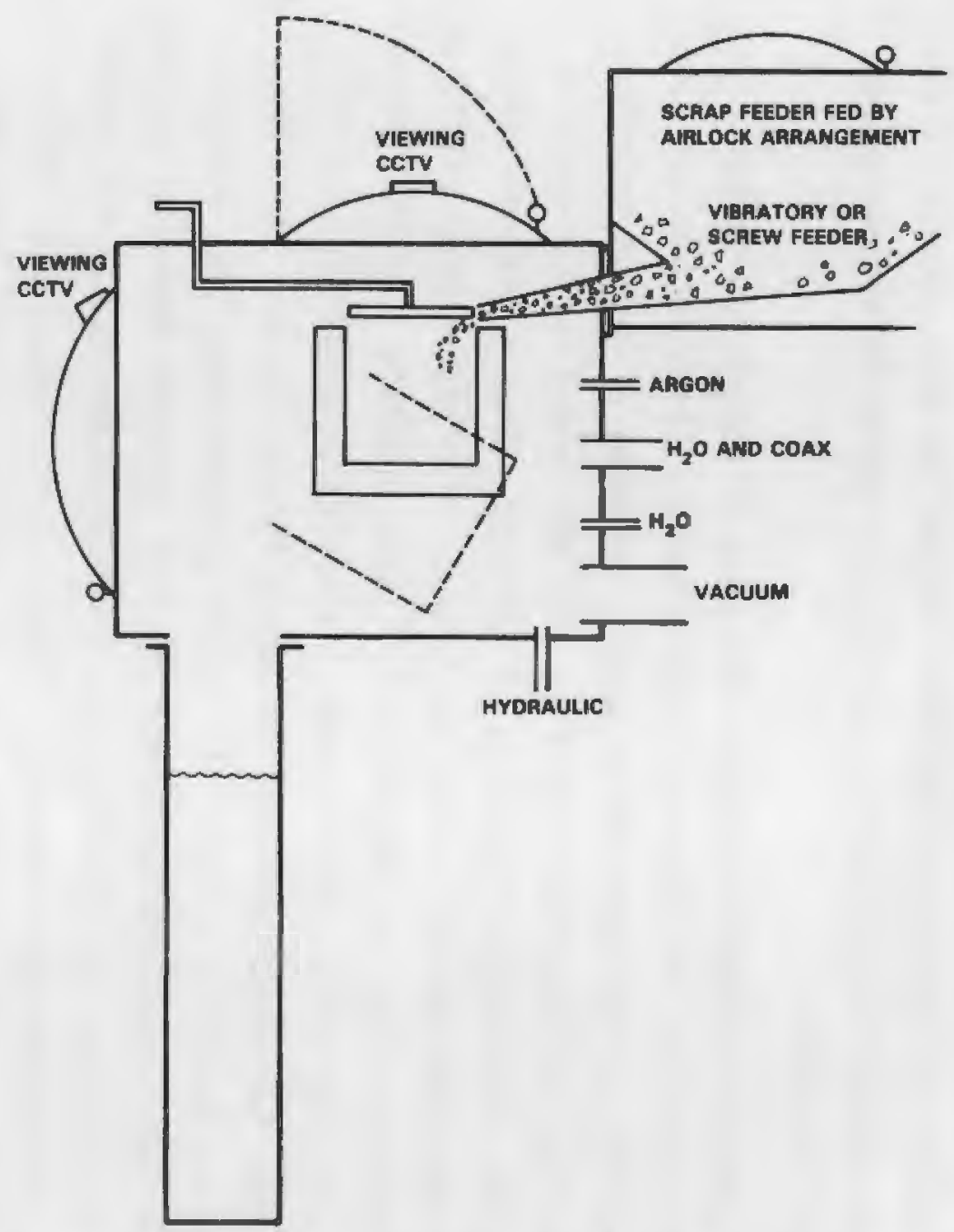

FIGURE E.4. Tilt-and-Pour Method for Vacuum Induction Melting Process 


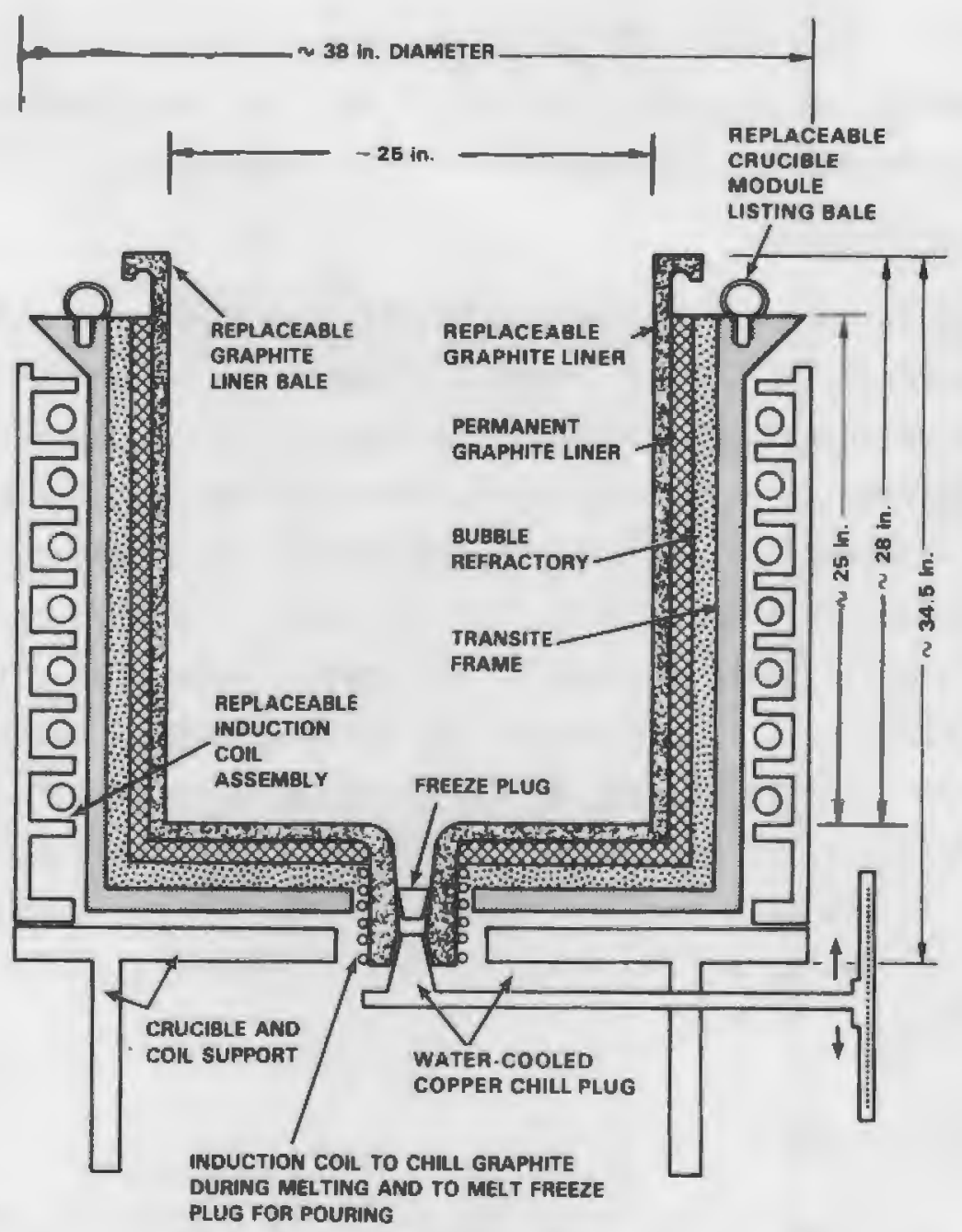

FIGURE E.5. Induction Melting Coil and Crucible Modules

barrels could be fed without interrupting the furnace atmosphere, or bulk scrap could be side fed into the crucible from an air lock feeder systen. This feeder system would hold enough metal to fill one or more canisters when melted. When feeding bulk metal pieces using the feeder chute, the maximum dimension should be $6 \times 6 \times 6 \mathrm{in}$. because of the danger of damaging the crucible or splashing an excessive amount of molten metal. For this reason, it may be prudent to segregate the metals by alloy and size and feed the hulls through the feeder system. Larger pieces could be charged into the crucible in a charging bucket or in 55-gal barrels. Another option would be to place the larger pieces in a canister and encapsulate them with molten metal poured from 
the crucible. Obviousiy, the metal would have to be placed in the canister so that the molten metal penetrated the interstices and flowed around the pieces, effectively encapsulating them within the canister.

\section{Furnace Operation}

Enough scrap metal is charged to the feed hopper to fill the canister with solidified ingot. If 55-gal barrels of metal are to be used as the charge, an air locked charging system allows the charging of one barrel at a time to the crucible without interrupting the furnace atmosphere. The power to the induction coil is turned on, and the charge is fed and melted until - $1365 \mathrm{~kg}$ of metal is melted in the crucible. If the metal is poured by the bottom pour method, the chill block is lowered and swung to one side. The power to the small induction coil is activated; and the freeze plug and other frozen metal in the sprue area are melted, allowing the majority of molten metal to flow into the canister. This process is repeated three times before the canister is 90\% full. If the tilt-and-pour method is issued, the metal would be poured into the canister by tilting the crucible and pouring the metal over the lip of the crucible.

\section{FACILITY REQUIREMENTS}

Since the size of the induction melter is similar to that of the Inductoslag melters, it is assumed that this furnace would fit into the facility arrangements shown in Figures A.5, A.7, and A.8 with some rearrangement. Off-Gas System

The estimated flow rates and constituents in the vacuum induction melting off-gas system are listed below:

$\begin{array}{ll}\frac{\text { Effluent }}{\text { Gases }^{(a)}} & \frac{\text { Flow Rate }}{30 \mathrm{~m}^{3} / \mathrm{min}} \\ \text { Particulates }^{\text {(b) }} & 4.0 \mathrm{~kg} / \mathrm{h}\end{array}$

(a) From furnace at $600^{\circ} \mathrm{C}$ and $1 / 3 \mathrm{~atm}$.

(b) Metal fumes contaminated with radioisotopes. 
Secondary Hastes Reguiring Processing

Wastes from the vacuum induction melting system that will require pracess ing are listed below:

$\begin{array}{ll}\frac{\text { Material }}{\text { Nonradioactive cooling water }} & \frac{\text { Amount }}{1000 \mathrm{~g} / \mathrm{min}} \\ \text { Process wastes } & 15 \mathrm{~kg} / \mathrm{h} \\ \text { Ventilation flow } & 500 \mathrm{~m}^{3} / \mathrm{min}\end{array}$

Utilities, Services, and Materials

Estimates of the normally required utllities, services, and materials that will be required for the vacuum induction melting system are indicated in Table E.1.

ASSESSMENT DISCUSSION

The numerical ratings assigned to the process by the individual evaluators are presented in Tables E.2 through E.5 (see $P$. E.12). The criteria are discussed below.

Complexity of Process

Material Handling. The equipment and the steps requited to handle the various process materials are considered to be about the same as those required for the nonconsumable electrode process (Appendix $B$ ).

Cansolidation Mode. As impliexd by its name, the vacuum coreless induction melting process melts metals under a protective atmosphere or vacuum by induction.

Matintenance Considerations and Equfpment Reliablity. The equipment pequired for this furnace system is anticipated to be more reliable than the equipant required for the reference systen. The battom pour mode requires less complicated equipment in the furnace, and lighter and less complex crucible and coil arrangements will suffice. Less equipment and matntenance will be required than for the reference system. 
TABLE E.1. Utilities, Services, and Materials for Vacuum Careless Induction Melting Process

\begin{tabular}{|c|c|c|c|}
\hline Item & Capacity & Average Rate & Amount/Year \\
\hline Electricity & $1000 \mathrm{kH}$ & $800 \mathrm{ta} 900 \mathrm{kH}$ & \\
\hline Water & $1 \mathrm{~B} 00 \mathrm{\&} / \mathrm{mi} \Pi$ & $1200 \mathrm{f} / \mathrm{min}$ & \\
\hline Air & $750 \mathrm{~m}^{3} / \mathrm{min}$ & $500 \mathrm{~m}^{3} / \mathrm{min}$ & \\
\hline Steam & $15 \mathrm{~kg} / \mathrm{h}$ & $2 \mathrm{~kg} / \mathrm{h}$ & \\
\hline Canisters & $2 \mathrm{ft}$ dia $\times 10 \mathrm{ft}$ long & & 133 \\
\hline He sources & & & 150 \\
\hline Crucible liners & & & 140 \\
\hline Argon & & & $2300 \mathrm{~m}^{3}$ \\
\hline
\end{tabular}

Controls and Operation. The operation of and controls for this process are deemed to be less complex than those for the reference process.

Adaptability to Remote Operations. Similar larger furnaces of this concept are common in the metal melting industry and could be adapted for and used in fully rempte nuclear processes after an adequate development, design, and testing period.

Number of Process Steps. About 28 process steps that consist of four batches of continuous process steps are required to fill a canister with molten metal. For the complete processing of equivalent amounts of material, this process requires about half the process steps of the reference process,

Feasibility of Production. One furnace and its supporting equipment is deemed feasible for production with considerable surplus capabilities.

Feed Limitations. This furnace will have fewer feed limitations than the reference process and about the same limitations as the nonconsumable electrode furnace (Appendix B).

State and Type of Developinent

Process and/or Equipment. With the exception of the botton pour crucible, furnaces of this or similar concepts are ane of the major meiting methods presently in operation in various industries. 
Type and Scale of Development. Developments that will be required prior to actual hot cell operation of a vacuum coreless induction furnace include:

- investigate the capability of melting a variety of mixtures of metals

- determine off-gas temperatures and the system to adequately process the contaminated off gases and particulates

- develop and test systems to monitor furnace operation remotely

- develop and demonstrate systems to feed the furnace remately

- determine the life of crucible materials

- test the rellability of the bottam pour method

- demonstrate the remote operation and reliability of a large-scale furnace

- identify the means to remove and replace the furnace and components remotely

- demonstrate the remote handling of containers.

Development Time Requjred. The required design, fabrication, and testing could be done in a period of 24 months.

Safety.

Two primary hazards are associated with the induction melting system in addition to the normal cancerns regarding the processing of radioactive materlal:

- A water leak could accur in the induction coll cooling system.

- Finely divided metallic residues that deposit on interior melt chamber surfaces during normal melting (especially zirconium) are a potential fire hazard when the furnace chamber is opened or dir is introduced.

Other potential hazards (crucible fallure, spills, etc.) are common to conventional melting of metals. For this ingot process, it has been estimated that 
the maximum amount of molten metal would be $m 1400 \mathrm{~kg}$. Its temperature could be as high as $1900^{\circ} \mathrm{C}$.

Since all radioactive material will be processed in shielded hot cells and devices designed for that purpose, the amount of excess radiation exposure will be a function of equipment maintenance and replacement, process accidents, or equipment failures.

Process Reyuirements

Secondary Hastes and Dff Gases. Off-gas system requirements will be about the same as those of the reference process. The amount of process wastes may be greater than for the reference process due mainly to the use of crucible liners.

Production Capacity. One furnace can process the projected throughput with considerable excess capacity*

Process Additives and Auxillary Materials/Utilities. Gas and water requirements are estimated to be about the same as for the reference process. Required power may be $15 \%$ less. One consumable crucible liner per canister produced is anticipated.

Process Versatility and Control. Like the reference process, this process will handle and nelt $a$ wide range of metals and mixtures. Because this material is cast inside a container or canister, a wider range of metal mixes, batches, and foreign materials could be processed wichout imposing a potential quality control problem of ingot or casting integrity.

Manpower. Due to a shorter furnace cycle than the reference process, this pracess wil only need to run -71 days/year or less than one-half the time required for the reference process.

Facillty Requirements

The facility required to enclose and support this process will be about the same as that identified for the reference process or facility; the equipment will be less complex. 
REFERENCES

Kotzin, E. 1972. Metal Casters Reference and Guide. American Foundryman's Society, Des Plaines, Tlinnois.

Nelsan, R. G*, and B. Griggs, 1976. Chop-Leach Fuel Bundle Residues Densification by Melting. BNWL-2132, Pacific Northwest Laboratory, Richland, Washington.

Westeman, R. E. 1962, Investigation of Pryolytic Graphite as Crucible Material for Zirconium Melting. प्रW-72998, General ETectric, hanford Atomic Products Operation, Riehland, Washington. 
TABLE E.2. Coreless Induction System Evaluation - Evaluator A

Complexity of Process

Material Handing

Consolidation Mode

Maintenance Considerations and Equipment Reliability

Controls and Operation

Adaptability to Remate Dperation

Number of Process Steps

Feasibility for Production

Feed Limitations

State and Type of Development

Process

Equ i pment

Type of Development

Scale of Development

Development Time Requirad (from

initiation of program)

Safety

Stability and Atmosphere of Process Steps

Pyrophoricity, Exothermic; and Exploston Considerations

Personnel Radiation Exposure

Process Requírements

Secondary Wastes and of $f$ Gases

Production Capacity

Pracess Additues and Auxiliary Materials

Process Versatility and Control

Quality Assurance

Utilities (air, power, water, etc.)

Manpower

Facility Reguírements

Noncontact Facilities (remote)

Cuntact Facilities (hands-on)

Estunated Capital Cost

Total
Factor Heighting

Sub

Tota?

60

Rating Assigned

Sub

Tota!

435

5

5

12

40

45

96

8

64

60

40

45

45

40

265

35

70

60

10

10

5

40

350

10

20

10

60

40

90

160

100

30

219

25

36

30

35

30

18

45

30

220

10

80

80

60

10 
IABLE E.3. Coreless Induction System Evaluation - Evaluator B

Complexity of Process

Material Handling

Consalidation Mode

Maintenance Considerations and Equipment Rellability

Controls and Operation

Adaptability to Remote Operation

Number of Process Steps

Feasibllity for production

Feed Limltations

State and Type of Development

Process

Equipment

Type of Development

Scale of Developinent

Developinent Time Required tifrom initiation of prograni)

Safety

Stability and Atmosphere of Process Steps Pyropharicity, Exotherinic, and Explosion Considerations

Personnel Radiation Exposure

Process Regut irements

Secondary Hastes and Off Gases

Production Capacity

Process Additives and Auxiliary Materials

Process Versacility and Control

Quality Assurance

Utilities (atr, power, water, etc.)

Manpower

Facllity Requirements

Noncontact Facilities (remote)

Contact Facilities (handsmon)

Estimated Capital cost
Factor Welghting Rating Assigned

$\begin{array}{rrr}\text { Sub } & \text { Total } & \text { Sub } \\ & 60 & \\ 5 & & 40 \\ 5 & & 50 \\ 12 & & 120 \\ & & \\ 15 & & 80 \\ 15 & & 90 \\ 5 & & 45 \\ 5 & & 50 \\ 5 & & 40\end{array}$

40

295

40

60

90

60

45

40

310

10

20

70

160

10

80

30

243

15

40

40

50

18

30

50

30

270

10

10

10

515

\section{0}

80

5

40

(1)

Tota 1 
TABLE E.4. Coreless Induction 5ystem Evaluation - Evaluator $C$

Complexity of Process

Material Handling

Consolidation Mode

Maintenance Considerations and Equipment Reliability

Controls and Operation

Adaptability to Remote Operation

Number of Process Steps

Feasibility for Production

Feed Limitations

State and Type of Development

Process

Equipment

Type of Develapment

Scale of Development

Development Time Required (f rom

initiation of program)

Safety

Stablitity and Atmosphere of Process 5teps

Pyrophoricity, Exothernit $c$, and Explosion Considerations

Personnel Radiation Exposure

Process Requirements

Secondary Wastes and off Gases

Production Capacity

Process Additives and Auxiliary Materials

Process Versatility and Control

Qua irty As surance

Utilities (air, power, water, etc.)

Manpower

Facility Requirements

Noncontact Facilities (remote)

Contact Facilities (hands-on)

Estinated Capital Cost

Total

Factor Weighting Rating Assigned

Sub

5

5

12

8

15

5

5

5

40

5

10

10

10

5

10

20

10

40

90

100

50

30

5
4
5
5
3
3
5

10

10

10

60

25

50

95

80

90

50

50

50

40

B0

90

80

45

240

335

441

441

.

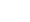


TABLE E.5. Coreless Induction System Evaluation - Evaluator D

Complexity of Process

Material Handing

Factor Weighting Rating Assigned

Sub $\frac{\text { Total }}{60} \frac{\text { Sub }}{300}$

Consolidation Hode

525

25

Maintenance Considerations and Equipment

12

72

Reliability

Controls and Dperation

Adaptability to Remote Dperation

$\begin{array}{ll}8 & 48 \\ 5 & 45\end{array}$

Aumber of Pracess Steps

45
25

Feasibility for Production

30

Feed Linitations

5

5

30

State and Type of Devel opment

40

240

Process

Equipment

10

10

Type of Development

Scale of Development

Development Time Required (from

10

initiation of program)

5 afety

40

150

Stability and Atmosphere of Process Steps 10

80

Pyrophoricity, Exothermic, and Explosion

20

Considerations

Personnel Radiation Expusure

Process Requirements

30

202

Secondary Wastes and off Gases

Production Capacity

5

20

Process Additives and Auxiliary Materials

30

60

50

$E D$

40

Process Versatility and Control

Quality Assurance

vtitities (air, power, water, etc.)

Manpower

35

18

18

45

Facility Requ i rements

30

240

Noncontact Facillites (remote)

10

80

Contact Facillities (hands-an)

Est mated Capital Cost 
APPENDIX $\mathrm{F}$

COLD COMPACTION 


\section{APPENDIX $F$}

\section{COLO COMPACTION}

\section{INTRODUCTION}

Processes for reducing the volume of radioactive hulls and high-level general process trash (HLGPT) wastes by cold compaction have been identified by Allied-General Huclear Services (AGNS) (1978) and Anderson et al, (1979). These processes were not intended to handle all the metallic wastes generated in a reprocessing facility--i, $\mathrm{e}_{m}$, falled equipment and the metal in the low level general process trash (LLGPT) or contact transuranfic (TRU) waste. However, they were to be capable of handling all HLGPT (metallics, organics, ceranics, combustibles, etc.). Thus, the size and capacity of these processes are assumed to be capable of handling and consolidating all of the metallic wastes identified in the Process Material Identification section ( $P$. 16$)$.

\section{PROCESS NEEDS AMD REQUIREMENTS}

The cold compaction process (Figure F.1) is basically a batchmtype operam tion that consists of a number of mechanical operations and transfers and very minimal chemical processing or changes (Anderson et al. 1979). In addition, very little off gas is generated. The process utilizes a comactor (Figure F.2) in a vertical position (Anderson et al. 1979). It is designed for an 8-ft 11-in. stroke, 3000-psi cylinder pressure, 10,000-psi developed compaction pressure, and $4.5 \times 10^{6}$ ib tatal force.

Hul1 Compaction Operations (Anderson et d1. 1979)

As depicted in Figure F.1, hulls are trucked to the facility in a hulls cask, which shields personnel fram the high radiation levels within the cantainer. The hulls container is assumed to be of AGNS design $444 \mathrm{in}$, in diameter by $B \mathrm{ft} h i g h$ ), and the cantainers are assumed to contain waste (mainly hulls) that has not had sand added at the Separations Facility. If sand were to be added, the compaction procedure would be the same except that the actual compacting step would be eliminated. 
The cask is 1 ifted by the 60 -ton crane holst and placed on top of the shielded hatch, which is in the ceiling of the compactor feed cell. The twopiece shielded hatch has a stepped opening to reduce radiation leakage and an electrically powered screw drive to open and close the hatch. The hatch door is an integral part of a fixture that mates to and supports the hulls transfer cask. The hulls container is lowered from inside the hulls cask to the shelf in the compactor feed cell via a captive hoist ir the hulis cask. The hulls container is subsequently moved from the shelf to the hulls container storage cell using the lo-ton compactor feed cell crane hoist. The container is then moved to a storage position within the storage cell using the hulls container storage cell 10mton crane hoist.

If the compactor is in operation, there may be no need to place the hulls container in storage. The container could be directly processed to the compaction step. The hulls storage area allows for a surge capacity to butld up, which could be helpful, particularly during periods af plant maintenance or hul ls transfer cask maintenance.

For the compaction process, a container is lifted from storage to the shelf area in the compactor feed cell. Using the compactor feed cell hoist; the container is lifted onto the dumper platform; and the lid is removed remotely using manipulators and in-cell tools. The container is securely fastened into the hulls dumper so that the adapter and the hulis hopper will mate and form a seal during dumping. This seal should substantially reduce the amount of contanination in the cell.

Using the compactar feed cell crane hoist, the platform and the attached hulls container are lifted above an upper pivot point and the hulls are dumged into the hopper. When the container is empty, it is detached from the dumper platform and the lid is remotely replaced. The empty container may be temporarily stored or it may be transferped out of the facility.

The hulls will be compacted into repositary containers that are $\sim 22$ in. outside diameter by $8 \mathrm{ft}$ long. Empty repository containers are obtained from the clean container storage with their lids light ly tack weided in place. 


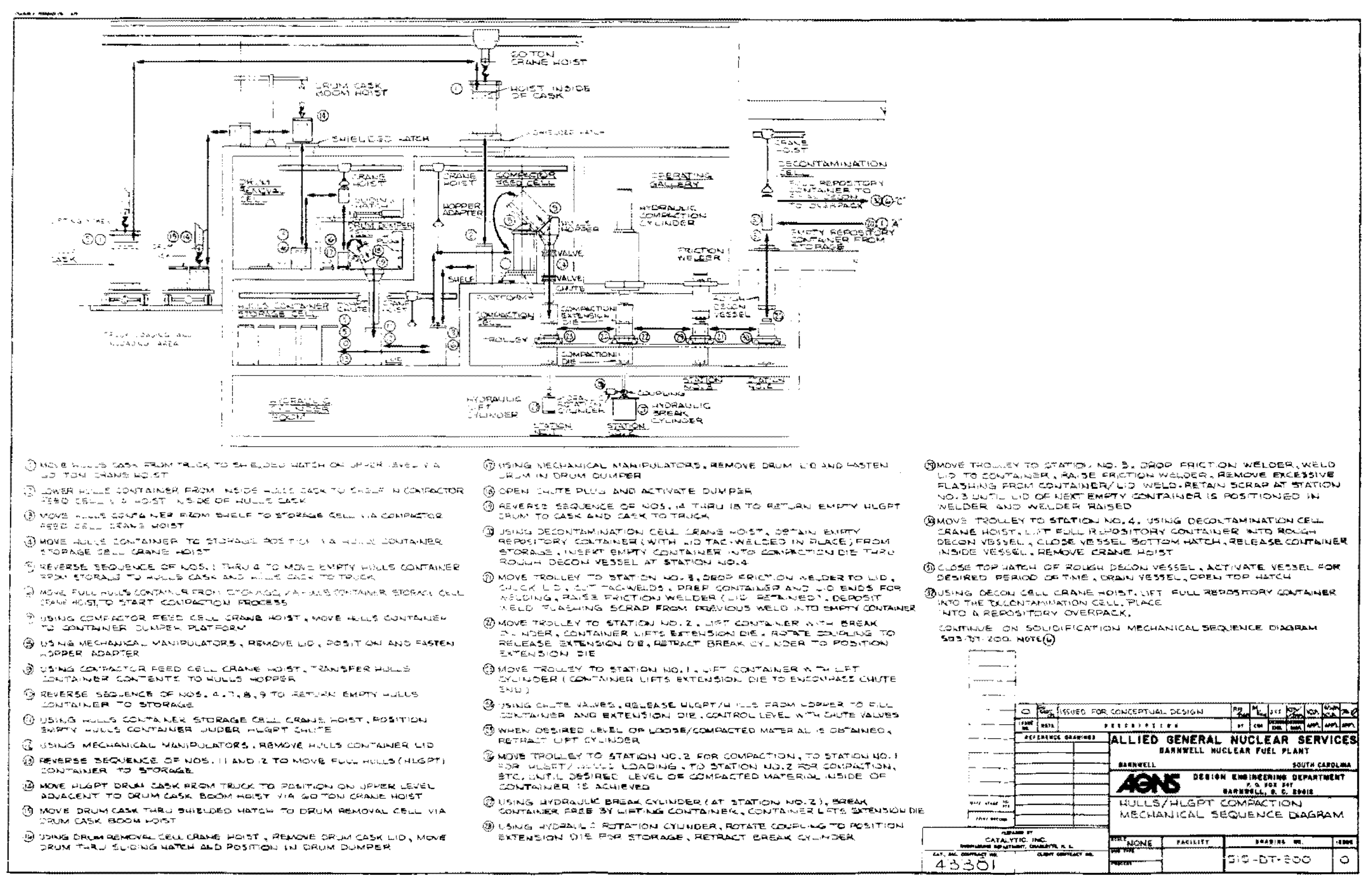




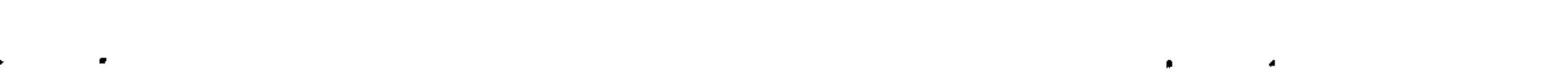




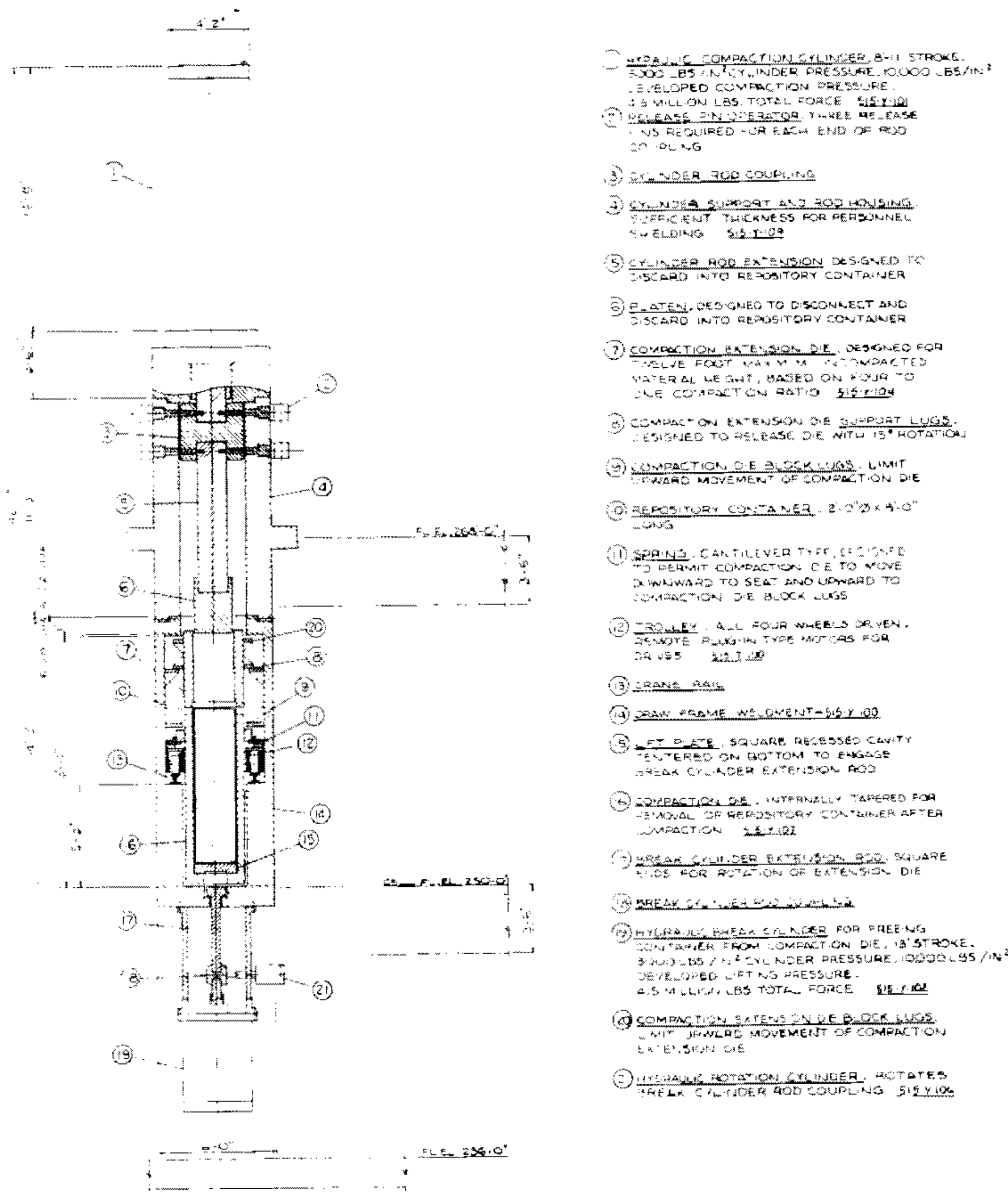

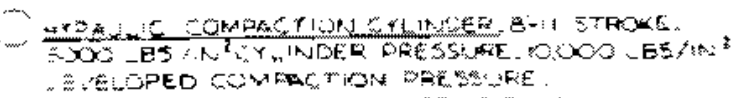

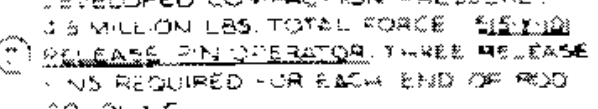

3)

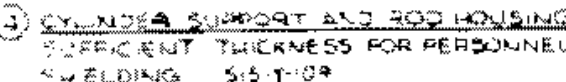

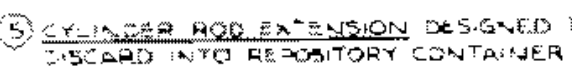

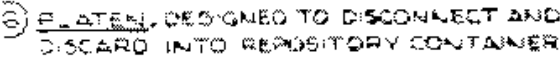

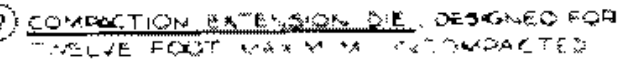

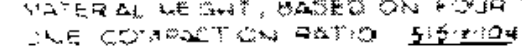

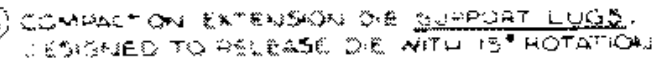

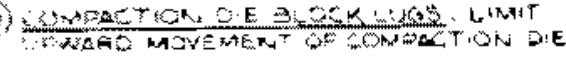

20.

J2A

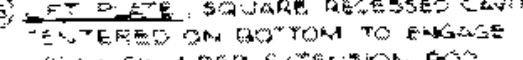

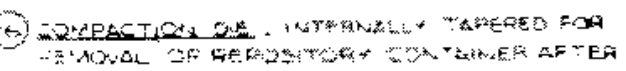

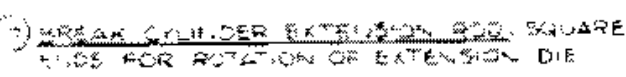

MRE

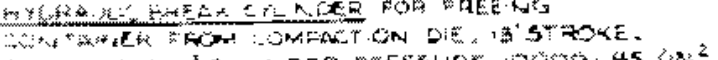
B.S

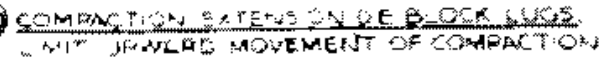

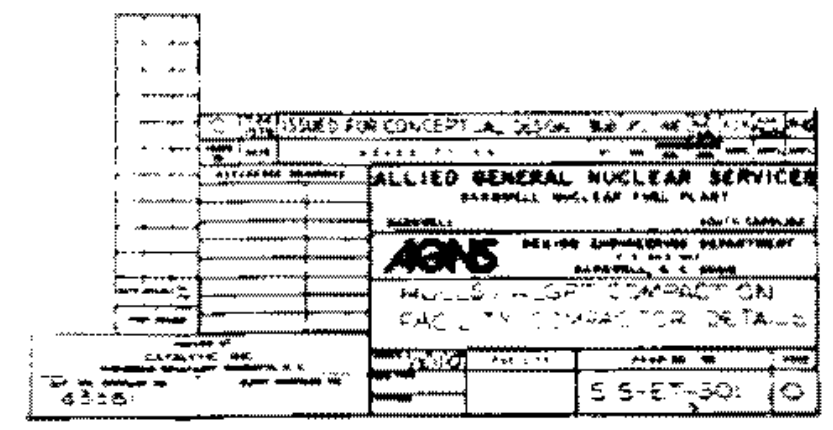



Using the decontamination cell crane hoist fincluded in the solldification facility), an empty container is inserted into the compaction die through the rough decontamination vessel at 5tation 4 .

The repositury container moves to station 3 on a trolley system that services compaction Stations 1 through 4 . At Station 3 , the friction welder/ delidder is placed on top of the lid and remotely clamped in place. The tack welds holding the lid in place are cut, and the container hid ends are prepared for a later friction weld. The friction welder/delidder is rajsed from the container but retains the lid. The weld flashing scrap from the tack welds is renoved by the friction welder/delidder, and the shavings from the weld preparation are deposited in the empty container.

The trolley moves the repository container to Station 2 where the container is lifted by the break cylinder. The container lifts the extension die from its norma storage position, and the hydraulic rotation cylinder is activated ta rotate the container and extension die. This rotation releases the extension die from its support lugs. The break cylinder is retracted, leaving the extension die sitting on top of the compaction die with the repository container in the compaction die. The dies and repository container are moved to Station 1 by the trolley. The container is lifted by the lift cylinder, which in turn lifts the extension die that encompasses the chute and of the hulls hopper.

Using the chute valves, a measured amount of hulls or scrap metal is released from the hopper and drops into the repository container* when the desired combined level of loose and previously compacted material is obtalned, the lift cylinder is retracted and the trolley moves to Station 2 for compaction. The hydraulic compaction is activated to compact the material. The trolley alternates between 5tations 1 and 2 , filling the container and compacting until the desired level of compacted material inside the container is obtained. It is expected that six to eight strokes (cycles) will be required to fill a repository container $80 \%$ to $90 \%$ full.

The repository container may have been press fitted into the compaction die during the compaction process. The hydraulic break cylinder is activated to push up on the lift plate where the container is sitting, causing the

$$
\mathrm{F} .7
$$


repository container to break free from the compaction die. To remove the con* talner from the die, it may be necessary to slightly taper the compaction die so that the top of the die is slightly larger than the hottom. The repository container may also be tapered so that the outer olameter is smaller at the bottom, thus allowing the container to break free from the compaction die when lifted from the bottom by the hydraulic break cylinder.

When the container breaks free from the compaction die, wit will also physically lift the captive extension die. Jsing the hydraulic rotation cylinder, the extension die will be placed back on its support lugs for temporary storage (until the next container is to be filled and compacted). The break cylinder is retracted so the trolley can move to Station 3 for welding. A friction welder is activated to weld the lid on the repository container. Excessive weld flashing is renoved from the contafner lid area and retained ab Station 3 until the next empty repository container is positioned on the welder; the flashing is placed in the container.

The trolley with the repository container is moved to Station 4. Using the decontamination cell crane holst, the full repository container is lifted into the rough decontamination station. The bottom of the vessel is closed by remote hydraulics (or a motor), and the container is released from the crane hoist. The crane hoist is lifted out of the way, and the upper hatch door to the rough decontanination vessel is closed. Decontamination solution is sprayed onto the container and drained from the sealed bottom of the station vessel. The upper hatch door is opened, and the crane hoist lifts the relatively clean repository container into the next call.

Other Waste Conpaction Operations (Anderson et al. 1979)

As indicated in Figure F.l, metallic scrap in HLGPT drums is brought to the compaction facility by truck in HLGPT casks. Individual casks are lifted by the 60mton crane hoist to a position above the drum removal cell. At about the same time, a hulls container is placed below the HLGPT chute. The HLGPT drum cask is lowered through the drum renoval cell shielded hatch using the drum cask boom hoist. Using the drum removal cell crane hoist, the cask lid is removed and a drum is lifted above and through the sliding hatch above the drum dumper cell. An individual drum is positioned in the drum dumper and secured 
in place. The drum lid is removed using mechanical manipulators. The HLGPT chute plug is removed and the drum dumper is activated, which tilts the drum until the contents fall down the chute and into a wating huls cantainer. The sequence is reversed to return an empty hiLGPT drum to the cask and the cask to the truck:

The hulls cask, which has been filled with the metallic waste, sits in the hulis container storage cell (just as hulls waste would awating compaction. The subsequent operations are identical to those described above.

Based on data reported by AGNS (1979) and adding the requil rement of prom cessing other metallics in addition to hulls, it has been projected that 300 canisters $2 \mathrm{ft}$ in diameter by $9 \mathrm{ft}$ long and filled to 90 capacity would be required each year. The contatned metallics would be pressed to $~ 50 \%$ of their melted or cast densities. Tw canisters per shift (six per day) could be prom duced; thus, the systen would be in operation 50 days of the year.

Equipment Ident ification

The major equipment used in the comaclion process and facility operations is identified in Table F.1 (Anderson et a1. 1979).

\section{FACILITY REQUIREMENTS}

The facllity will be constructed af nomal density concrete. In general, mose of the cell walls wll be 42 in. thick. Overviews of the upper and lower levels of the facility are shown in Figures F.3 and F.4 (Anderson et al. 1979), and an lsometric wew of the compaction factility is shown in Figure $F .5$ (Andersor et al. 1979). Components of the facility are described in Table F.2 (Anderson et al. 1979).

\section{Off-Gas System}

Off gases from the compactor, the dumping device, and the remate welder pass through a venturi scrubber where the majority of the particulates are removed. The off gas is then copled in the cooler-condenser, separated from the condensate in the separator, heated above its dew point in the reheater, and filtered through a roughing filter and a high-efficiency particulate air 


\section{TABLE F.1. Equipment Description for Cold Compaction Facility}

\begin{tabular}{|c|c|c|c|c|}
\hline Bullding Area & Quantity & Descrlption & Materlal & Dimensions \\
\hline \multirow[t]{4}{*}{ Poof } & 1 & so-ton crane & Carbon steel & 22-1n. span \\
\hline & 1 & 10-ton $\operatorname{cran} \theta$ & Carbon steol & $15-f t$ boom \\
\hline & 1 & $\begin{array}{l}\text { Pneumatic-operated roof } \\
\text { plug }\end{array}$ & $\begin{array}{l}\text { Concretedstainless } \\
\text { steel }\end{array}$ & $\begin{array}{l}60 \text { in. diax } \\
41 \text { in. thlck }\end{array}$ \\
\hline & 1 & $\begin{array}{l}\text { Guillotine door (for hul is } \\
\text { cosk) }\end{array}$ & $\begin{array}{l}\text { Concrete/staln less } \\
\text { steel }\end{array}$ & $\begin{array}{l}6 \mathrm{ft} \times 12 \mathrm{ft} \times \\
42 \mathrm{in} \text {. thick }\end{array}$ \\
\hline Drum remova I cell & 1 & 10-ton crane & Carbon steel & $14-f t$ span \\
\hline \multirow[t]{4}{*}{ Drum dunper cell } & 1 & Drum dumer ${ }^{(a)}$ & Stain less steel & \\
\hline & 1 & Floor plug & Concrete/stain less & 36 in. diax \\
\hline & & & $5+\infty \theta$ & 42 In. thick \\
\hline & 1 & Roof went door ${ }^{(a)}$ & Stainless steel & $\begin{array}{l}60 \text { in. dia } x \\
4 \text { in. thick }\end{array}$ \\
\hline \multirow[t]{4}{*}{ Compactor feed cell } & 1 & Hul Is hopper and valves & Stainless steel & \\
\hline & 1 & Hul Is dumper and adaptor & Stalnless steel & \\
\hline & 1 & 10-ton $\operatorname{cran} \theta$ & Stainless steel & 26-In. span \\
\hline & 1 & Shielding door ${ }^{(a)}$ & Concretedstaln less & $30 \mathrm{ft} \times 16 \mathrm{ft}$ \\
\hline $\begin{array}{l}\text { Operating gellery } \\
\text { (elevation } 268 f t)\end{array}$ & 1 & Friction wider & $\begin{array}{l}\text { Stainless steel } \\
\text { Stalnless steel }\end{array}$ & $\begin{array}{l}\text { For 24-ln. dia } \\
\text { cylinders }\end{array}$ \\
\hline \multirow{3}{*}{$\begin{array}{l}\text { Hydraullc cylinder } \\
\text { room (elevation } 236 \mathrm{ft} \text { ) }\end{array}$} & 1 & Lift cyllnder & Stain less stael & \\
\hline & 1 & Break cylinder & Stainless steel & \\
\hline & $\mathbf{i}$ & Hydraulle rotation cylinder & Staln less steel & \\
\hline \multirow[t]{5}{*}{ Conpaction celi } & 1 & Extenston die & Stainless steol & \\
\hline & 1 & Cormactor & Staln less steel & \\
\hline & 1 & Compactor dle assembly & Stainless steel & \\
\hline & 1 & Compactor trolley & Staln less steel & \\
\hline & 1 & $\begin{array}{l}\text { Rough decontanination } \\
\text { vessel }\end{array}$ & Stainless steel & \\
\hline $\begin{array}{l}\text { Hul is contalner } \\
\text { storage cell }\end{array}$ & 1 & 10-ton crane & Stainless sterel & 26-ft span \\
\hline $\begin{array}{l}\text { Mechanical } \\
\text { equipment room }\end{array}$ & 1 & Hydraul ic power package & Carbon steel & \\
\hline
\end{tabular}

(a) Renotely operated. 


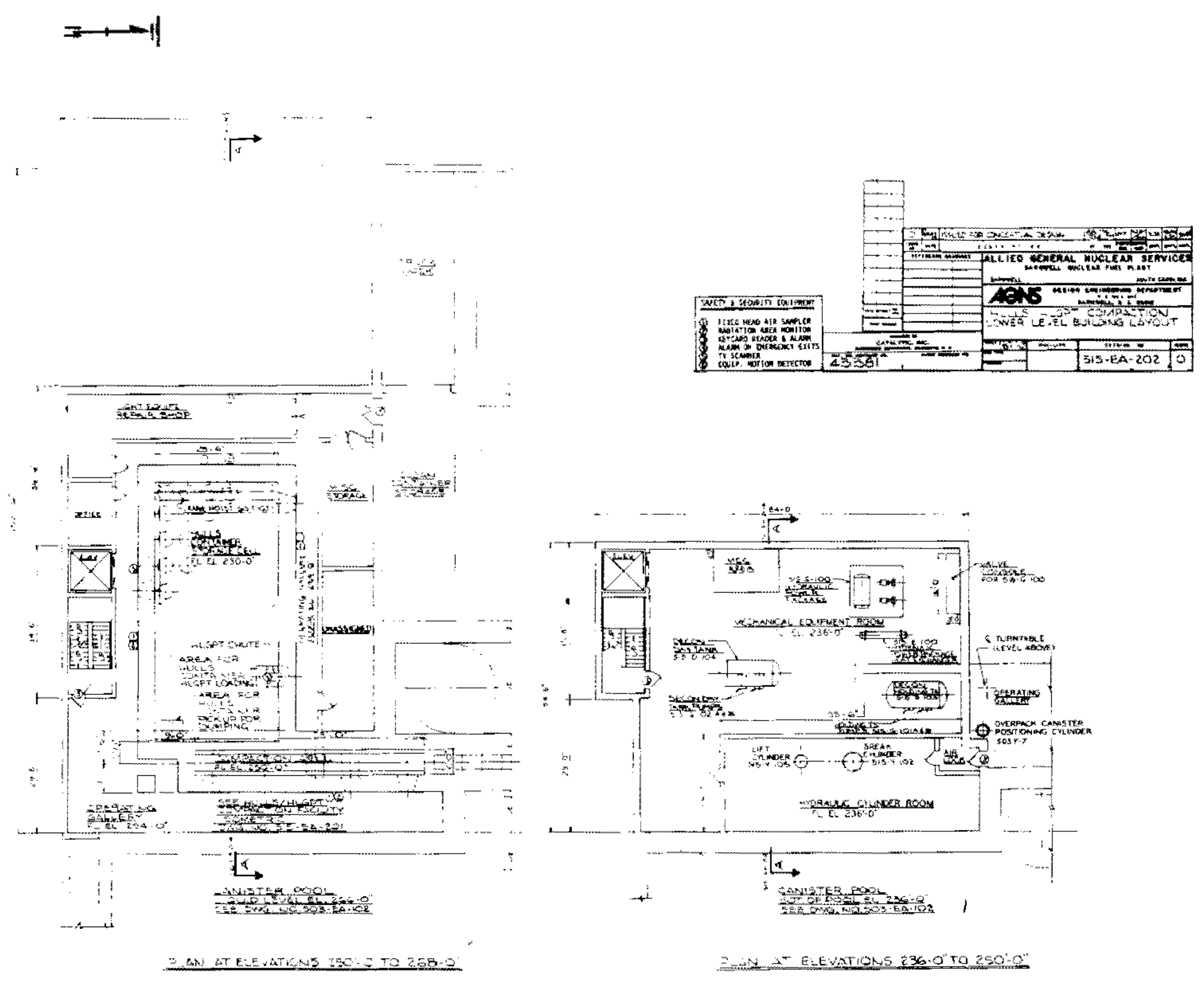

FIGURE F.3. Luwer Level Building Layout for Cold Compaction Facility 



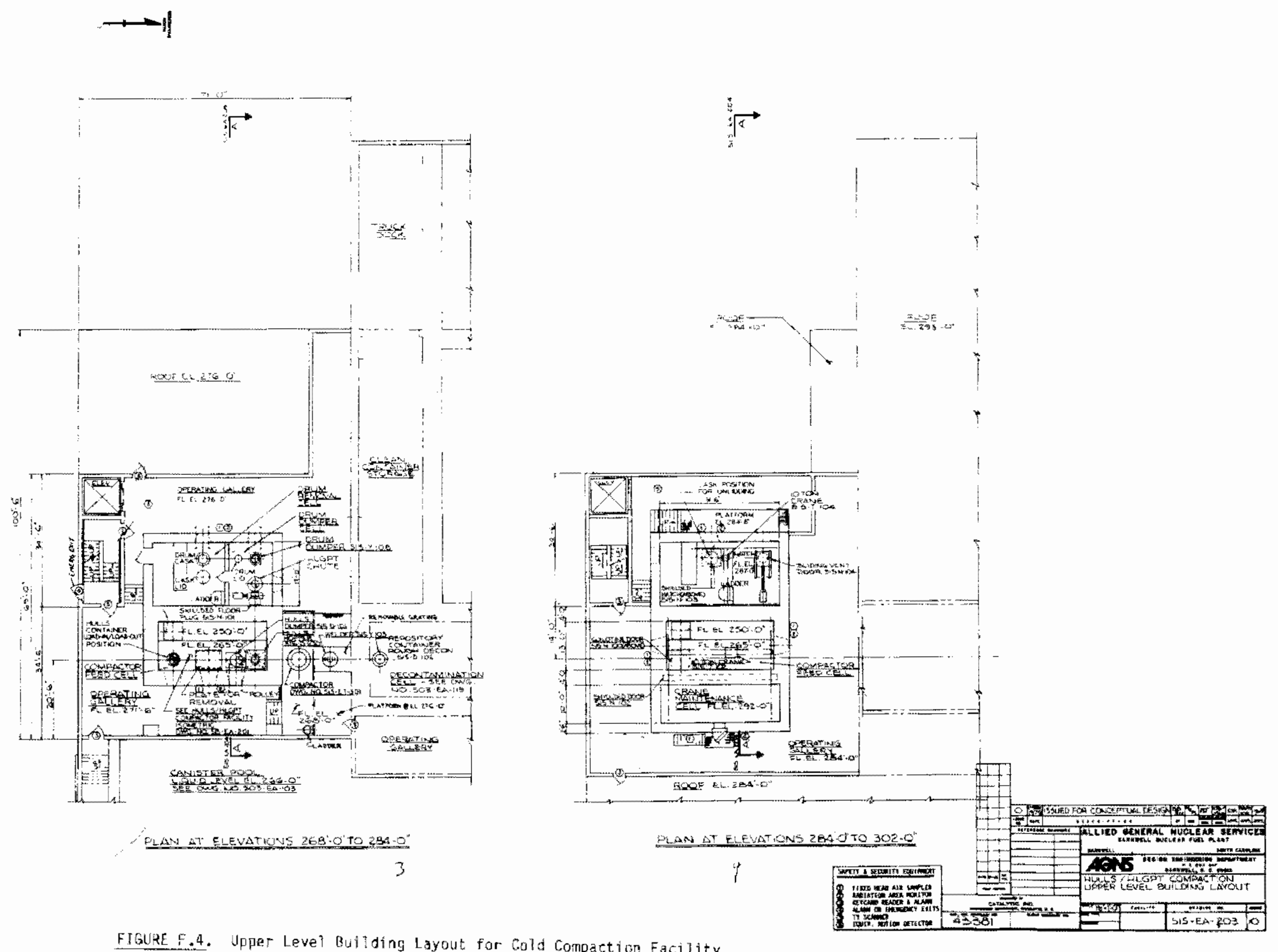

FIGURE E.4. Upper Level Bullding Layout for Cold Compaction Facility 

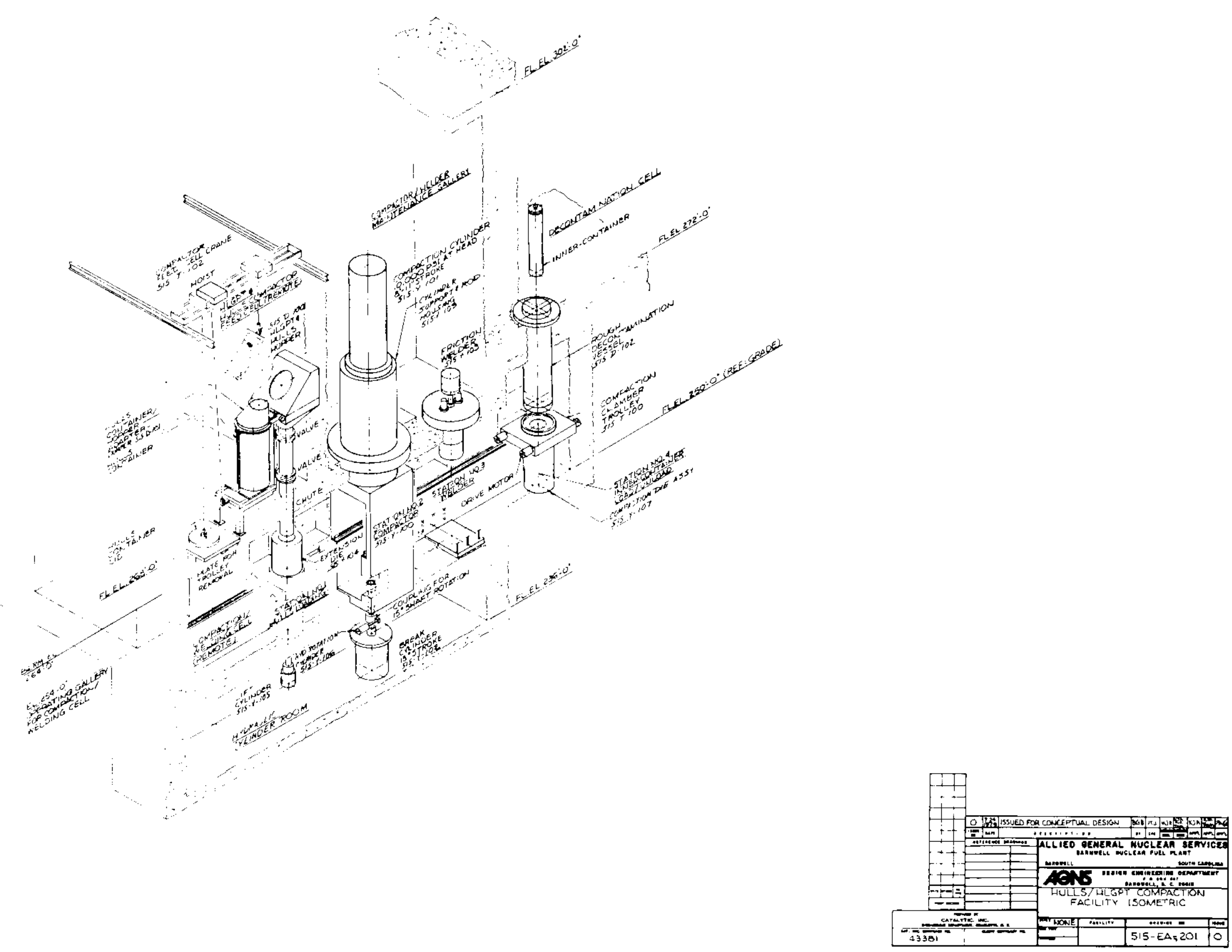

FIGURE F.5. Isometric View of Cold Compaction Facility 

Using the decontamination cell crane hoist fincluded in the solidification facility), an empty container is inserted into the compaction die through the rough decontanination vessel at 5 tation 4 .

The repository container moves to Station 3 on a trolley system that services compaction 5 atjons 1 through 4. At Station 3, the friction welder/ delidder is placed on top of the lid and remotely clamped in place. The tack welds holding the lid in place are cut, and the container lid ends are prepared for a later friction weld. The friction welder/delidder is raised from the container but retains the lid. The weld flashing scrap from the tack welds is removed by the friction welder/delidder, and the shavings from the weld preparation are deposited in the empty container.

The trolley moyes the repository container to Station 2 where the container is lifted by the break cylinder. The cantainer lifts the extension die from its normal starage position, and the hydraulic rotation cylinder is activated to potate the container and extensian die. This rotation releases the extension die from its support lugs: The break cylinder is retracted, leaving the extension die sitting on top of the compaction die with the repository con* tainer in the compaction die. The dies and repository container are moved to station 1 by the trolley. The container is lifted by the lift cylinder, which in turn lifts the extension die that encompasses the chute end of the hulls hopper.

Using the chute valves, a measured amount of hulls or scrap metal is released from the hopper and arops into the repositary container. When the desired combined level of loose and previously comacted material is obtained, the lift cylinder is retracted and the trolley moves to 5 tation 2 for comacm tion. The hydraulic compaction is activated to compact the material. The trolley alternates between Stations 1 and 2, filling the contalner and compacting until the desired level of compacted material inside the container is obtained. It is expected that six to eight strokes (cycles) will be required to fill a repository container $80 \%$ to $90 \%$ full.

The repository container may have been press fitted into the compaction die during the compaction process. The hydraulic break cylinder is actlyated to push up on the lift plate where the container is sitting, causing the

$$
\text { F. } J
$$


repository container to break free from the compaction die. To remove the contaner from the die, it may be necessary to slightly taper the compaction die so that the top of the die is slightly lapger than the bottorn. The repository container may also be tapered so that the outer diameter is smaller at the bottom, thus allowing the container to break free from the compaction die when lifted from the bottom by the hydraulic break cylinder.

When the container breaks free from the cornpaction die, it will also physically lift the captive extension die. Using the hydraulic rotation cylinder, the extension die wll be placed back on its support lugs for temporary storage (until the next container is ta be filled and compacted). The break cylinder is retracted su the trolley can move to 5 tation 3 for welding. A friction welder is activated to weld the lid on the repository container. Excessive weld flashing is removed from the container lid area and retained at Station 3 until the next enpty repository container is positioned on the welder; the flashing is placed in the container.

The trolley with the repository container is moved to Station 4 . Using the decontamination cell crane hoist, the full repository container is lifted into the rough decontamination station. The bottom of the vessel is closed by remote hydraulics (or a motor), and the container is released from the crane hoist. The crane hoist is lifted out of the way, and the upper hatch door to the rough decontamination vessel is closed. Decontamination solution is sprayed onto the container and drained from the sealed bottom of the station vessel. The upper hatch door is opened, and the crane hoist lifts the relatively clean repository container into the next cell. Other Waste Compaction Operations (Anderson et al. 1979)

As indicated in Figure F.1, metallic scrap in HLGPT drums is brought to the compaction facility by truck in HLGPT casks. Individual casks are lifted by the 60-ton crane haist to a position above the drum removal cell. At about the same time, a hulls container is placed below the HLGPT chute. The HLGPT drum cask is lowered through the drum renoval cell shielded hatch using the drum cask boom hoist. Using the drum removal cell crane hoist, the cask lid is removed and a drum is lifted above and through the sliding hatch above the drum dumper cell. An individual drum is positioned in the drum dumper and secured 
in place. The drum lid is removed usting mechanical manipulators. The HLGPT chute plug is removed and the drum dumper is activated, which tilts the drum until the contents fall down the chute and into a wating hulls container* The sequence is reversed to return an empty HLGPT drum to the cask and the cask to the truck.

The hulls cask, which has been filled with the metallic waste, sits in the hulls container storage cell (just as hulls waste would) awaiting compaction. The subsequent operations are identical to those described above.

Based on data reported by AGNS (1978) and adding the requirenent of processing other metallics in addition to hulls, it has been projected that 300 canisters $2 \mathrm{ft}$ in diameter by $8 \mathrm{ft}$ long and filled to $90 \%$ capacity would be required each year. The contained metallics would be pressed to $250 \%$ of their melted or cast densities. Two cansters per shift (six per day) could be produced; thus, the system would be in operation 50 days of the year.

\section{Equipment Ident ification}

The major equipment used in the compaction process and facility operations is identified in Table F.1 (Anderson et a1. 1979).

\section{FACILITY REQUIAEMENTS}

The facllity will be constructed of normal density concrete. In general, most of the cell walls will be $42 \mathrm{in}$. thick. Overviews of the upper and lower levels of the facility are show in Figures F.3 and F.4 (Anderson et al. 1979), and an isometric view of the compaction facility is shown in Figure $F .5$ (Anderson et al. 1979). Components of the facllity are described in Table F.2 Anderson et a1. 1979).

\section{Off-Gas System}

Off gases from the compactor, the dumping device, and the remote welder pass through a venturi scrubber where the majority of the particulates are removed. The off gas is then codled in the coolermcondenser, separated from the condensate in the separator, heated above its dew point in the reheater, and filtered through a roughing filter and a high-efficiency particulate air 


\section{TABLE F.1. Equipment Description for Cold Compaction Factlity}

\begin{tabular}{|c|c|c|c|c|}
\hline Buliding Areo & Ouantity & Deser tet lon & Hartat & Qlnenglons \\
\hline \multirow[t]{5}{*}{ Foot } & 1 & 60-tan crane & Sarbon $\$$ tog 1 & $22-1 n_{+}$span \\
\hline & 1 & 10-ton erang & Carbon stogl & $15 m f+b o 0 n$ \\
\hline & 1 & Fneuraticroperated roof & Coneretelstainless & 60 inf d高 $x$ \\
\hline & & gug & stees & $41 \mathrm{in.}$ thick \\
\hline & 1 & $\begin{array}{l}\text { Sullotine door thor hul th } \\
\text { cask? }\end{array}$ & $\begin{array}{l}\text { Conergitestaintess } \\
\text { stoil }\end{array}$ & $\begin{array}{l}6 \text { \&t } \times 12 \text { tt } x \\
42 \text { in. thlck }\end{array}$ \\
\hline Drup remprol cell & 1 & 10-tan crang & Carbon stopi & 14-ft span \\
\hline \multirow[t]{4}{*}{ Drum dumper cell } & 1 & Drum dumper $(\mathrm{D})$ & Stalnless stee 1 & \\
\hline & 1 & F loor plug & Concreterstain lass & $36 \ln =$ dia $x$ \\
\hline & & & steel & 42 In. thl ck \\
\hline & 1 & Root wont door ${ }^{(a)}$ & Stalnios stae! & 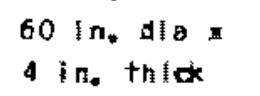 \\
\hline \multirow[t]{4}{*}{ Compactor tead cell } & 1 & Hul la hoper and val ves & Staintess steel & \\
\hline & 1 & Hulis dumper and adaptor & Stalntess etoel & \\
\hline & 1 & 10u+ton crane & Stainless stegt & 26-1 n, span \\
\hline & 1 & Shlalding door ${ }^{(\theta)}$ & Concreterstanfess & $30 \mathrm{ft} \times 16 \mathrm{ft}$ \\
\hline $\begin{array}{l}\text { Cperating gallery } \\
\text { telovetion } 268 \text { t t? }\end{array}$ & 1 & Friction oldor & $\begin{array}{l}\text { stain lass stom l } \\
\text { stalnlass stogl }\end{array}$ & $\begin{array}{l}\text { For 2d-1ne did } \\
\text { cyllinders }\end{array}$ \\
\hline Hydraulic cylinjar & 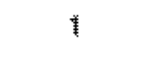 & Lift cyllnder & Statntess steel & \\
\hline \multirow[t]{2}{*}{ rode talevation 236 tt) } & 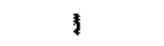 & Bresk cylinder & Staniess stagt & \\
\hline & 1 & Hraraullc rototion cyllinder & Staln less stoo & \\
\hline \multirow[t]{5}{*}{ Competion $\leq \cdot 1$} & 1 & Extension dite & Stalntess stant & \\
\hline & 1 & Compotor & Stalnless $s+00$ l & \\
\hline & 1 & Conpactor dis assembly & Stutioless steel & \\
\hline & 1 & Compactor trollay & stainless stoel & \\
\hline & 1 & $\begin{array}{l}\text { Reugh decontant nation } \\
\text { vosie! }\end{array}$ & stoln less stogi & \\
\hline storage coll & 1 & 10-tan crane & stolntess stent & 26-tt span \\
\hline $\begin{array}{l}\text { Hexchicat } \\
\text { equipment rocan }\end{array}$ & 1 & Matgulic power padkage & Carbon steal & \\
\hline
\end{tabular}

(a) Renotaly operatad: 


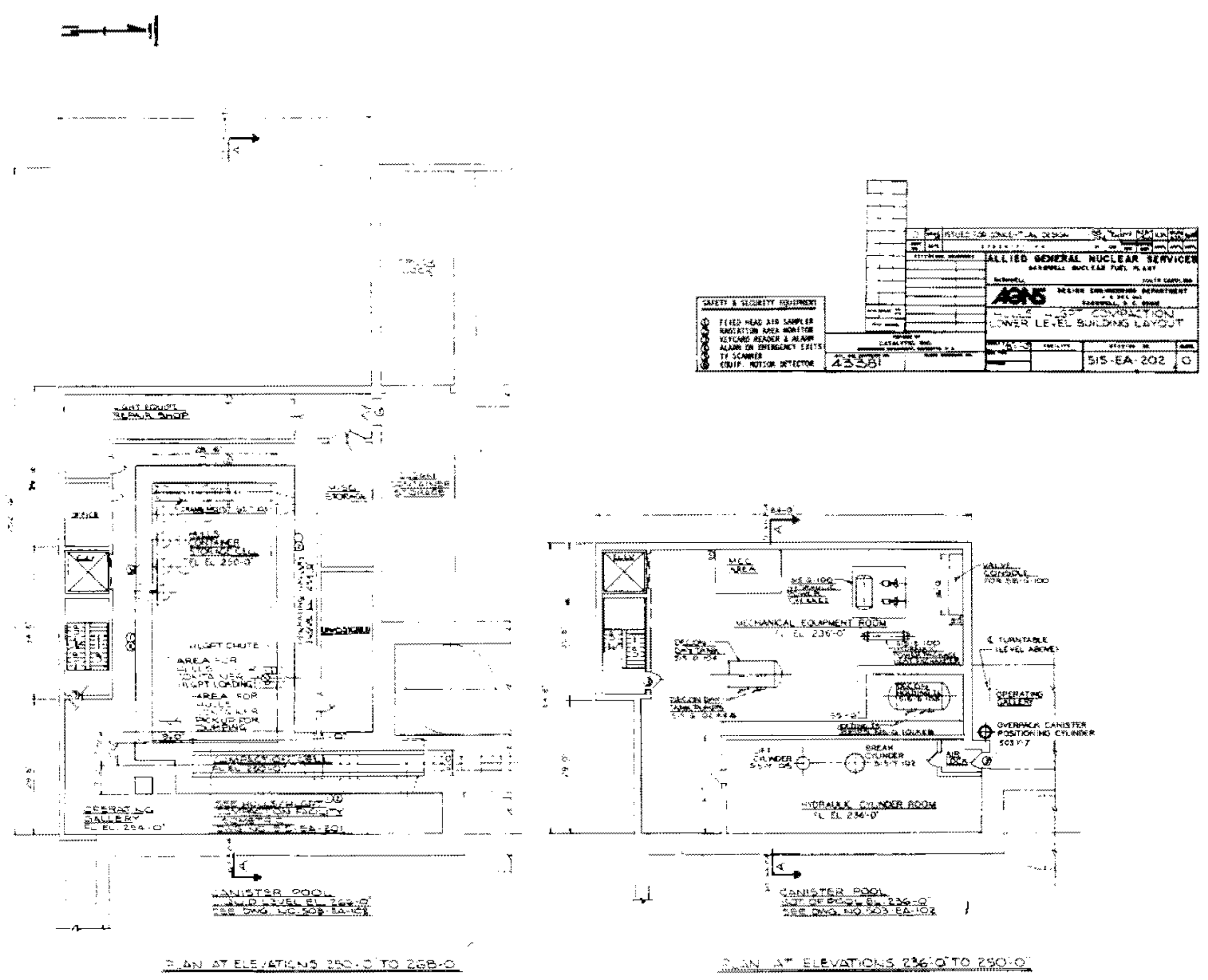

FIGURE F.3. Lawer Leve? Building layout for Cold Compaction Facility 


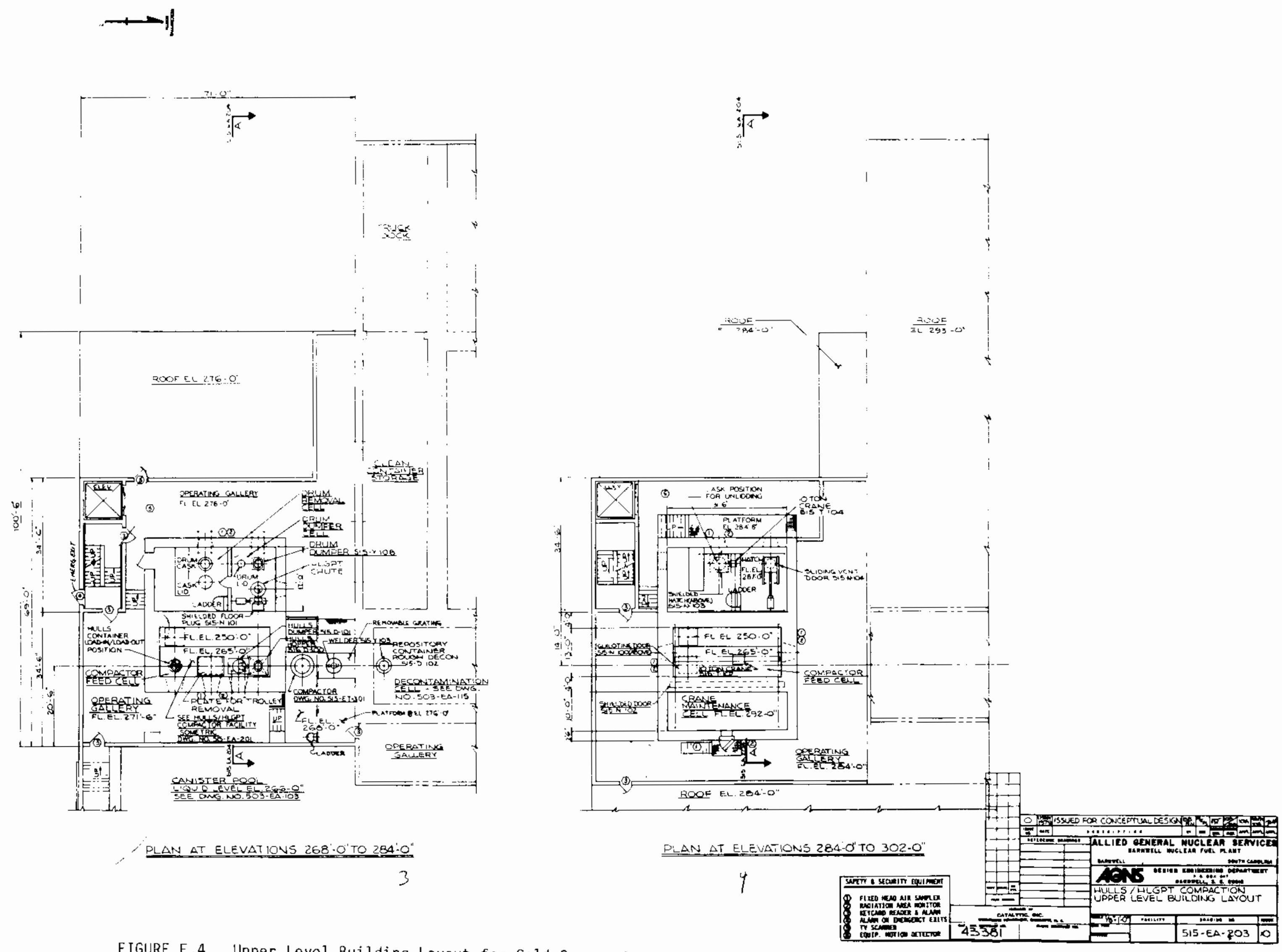

FIGURE F.4. Upper Level Building Layout for Cold Compaction Facility 
- 

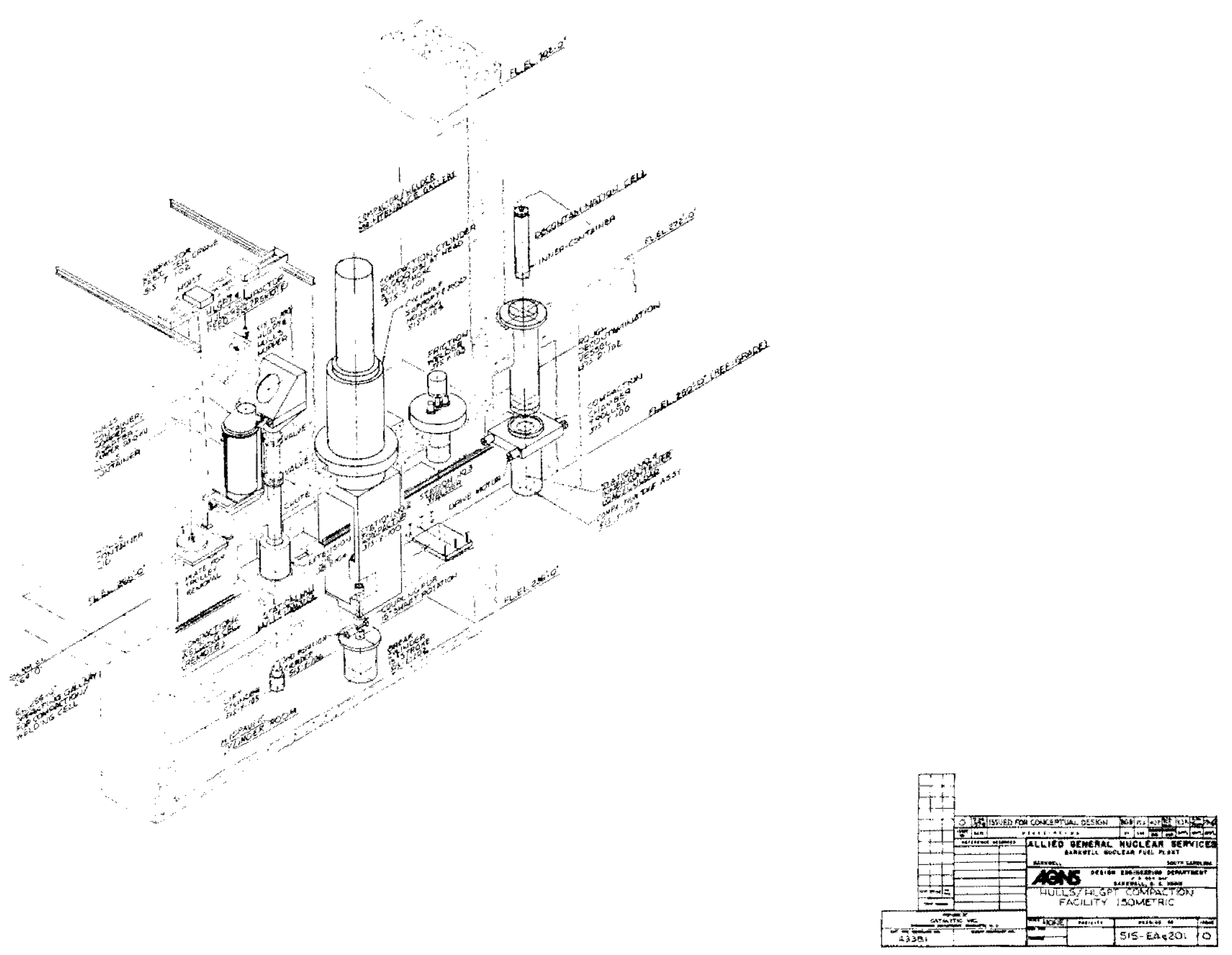

FIGLRE F.5. Isometric View of Cold Compaction Farsitity 

TABLE F.2. Cold Compaction Facility Description

\begin{tabular}{|c|c|c|c|c|c|c|c|c|}
\hline But1ding $\mathrm{A} \Gamma \mathrm{ga}$ & $\begin{array}{l}\text { Oparatlonal } \\
\text { Mode }\end{array}$ & $\begin{array}{l}\text { Mantenence } \\
\text { Mode }\end{array}$ & 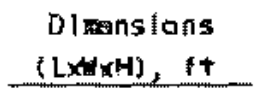 & Votime: & F poor & 11s & Sل的 & $\begin{array}{c}\text { Fire } \\
\text { Protection }\end{array}$ \\
\hline Root & Contact & Contect & - & 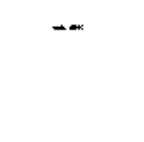 & $m$ & $-\infty$ & No & $\begin{array}{l}\text { Sprlinklar } \\
\text { where } \\
\text { required }\end{array}$ \\
\hline $\begin{array}{l}\text { Drum removal } \\
\text { cell }\end{array}$ & $\begin{array}{l}\text { Sontget/ } \\
\text { rtmots }\end{array}$ & Cantact & $18 \times 15.5 \times 22$ & $6,1,30$ & Epoxy & Epony & Yas & Sprlakier \\
\hline $\begin{array}{l}\text { Drum dumpor } \\
\text { cell }\end{array}$ & Remoto & Contact & $10 \times 15,5 \times 10$ & 1,50 & EDoxy & Epony & No & Sprinklat" \\
\hline $\begin{array}{l}\text { Compactor } \\
\text { foed cell }\end{array}$ & Reriote & Rexpte & $28,5 \times 19 \times 93$ & 12,226 & No t Joor & Epoxy & Ho & Halon \\
\hline $\begin{array}{l}\text { operating } \\
\text { gallery } \\
\text { (alewation } \\
\text { zadt) }\end{array}$ & Context & Contact & $\cdots$ & $\ldots$ & Epoxy & Epoxy & Ho & aprinklar \\
\hline $\begin{array}{l}\text { Horaul ic } \\
\text { cyllnder } \\
\text { rom }\end{array}$ & Contact & Confact & $-\infty$ & $m$ & $m+n$ & $-\infty$ & Yes & Sprlakler \\
\hline $\begin{array}{l}\text { Compaction } \\
\text { cell }\end{array}$ & Renotg & Renote & $53 \times 6 \times 14$ & 4,452 & $\begin{array}{l}\text { stainfoss } \\
\text { setoel }\end{array}$ & Epoxy & Yo5 & Halon \\
\hline $\begin{array}{l}\text { Hat ls con } \\
\text { tol ner } \\
\text { storage cell }\end{array}$ & Remoto & Regnote & $60 \times 28.5 \times 27$ & 37.620 & $\begin{array}{l}\text { stain lest } \\
\text { steal }\end{array}$ & Epoxy & Yes & thaton \\
\hline $\begin{array}{l}\text { Mochanich } \\
\text { exulpoxant } \\
\text { roon }\end{array}$ & contset & Contact & $-n$ & $m-\infty$ & $-\infty$ & $-\cdots$ & Yas & Sarinter \\
\hline
\end{tabular}


(HEPA) filter. The filtered of $f$ gas passes through redundant fans and is released to the bulliding exhaust system. Quantities and properties of the constituents entering the off-gas system are shown below:

\begin{tabular}{|c|c|}
\hline Temperature, "C & 50 \\
\hline Pressure, psia & 14.5 \\
\hline Density $1 \mathrm{~b} / \mathrm{ft}^{3}$ & 0.058 \\
\hline Flow, $m^{3} / m^{3} n$ & 2000 \\
\hline Flow, kg/h & 4300 \\
\hline Flow, $1 b-m o l / h$ air & 320 \\
\hline $\mathrm{Flow}, \mathrm{lb}-\mathrm{mol} / \mathrm{h} \mathrm{H}_{2} \mathrm{O}$ & 9.3 \\
\hline mol\% ais & 97 \\
\hline mols water & 2.8 \\
\hline
\end{tabular}

Secondary Wastes Requirigg Processing

Monradioactive solid and liquid wastes will be handied in supporting systems. These and other wastes that may contain radioactive nuclides that will require processing prior to release are listed below:

$\begin{array}{ll}\frac{\text { Material }}{\text { Nonradioactive cooling water }} & \frac{\text { Amout }}{500 \mathrm{k} / \mathrm{min}} \\ \text { Process wastes } & 10 \mathrm{~kg} / \mathrm{h} \\ \text { Ventllation } \mathrm{flow} & 500 \mathrm{~m} / \mathrm{m}^{3} \mathrm{n}\end{array}$

Ut llities, Services, and Materials

Ut llities, services, and materials that wlll be required for the compaction facility are summarized in Table F.3.

\section{ASSESSMENT DISCUSSION}

Considering the limitations of size, pressure, and force, it has been projected that it is anly feasible to fill a 2-ft dianeter by 8 mt long canister 
90\% full of metal compacted to $-50 \%$ of its apparent density. Thus, more canisters will be produced than fram most of the melting processes. The subsequent cost to transport and dispose of these canisters may eltminate the cold compaction process from further consideration. The numerical ratings assigned to the process by the individual avaluators are presented in Tabies $F .4$ through F.7 (see p. F. 23). The criteria are discussed below.

Complexity of Process

More complex equipment is required to cold press the process material in canisters than for an electrical melt furnace. Although the equipment is complex, the process and its controls and operation are relattively simple. No heating or cooling are required, and the process requires no additional materials or recycling. Oue to the complex mechanical equipment, there are concerns about satisfactory remote production. Maintenance modes and procedures for the equipment need to be identified and verified.

TABLE F.3. Utility, Services, and Materials for Cold Compaction Process

\begin{tabular}{|c|c|c|c|}
\hline Item & Capacity & Amount/Year & Remarks \\
\hline Essential air & $3 \mathrm{~m}^{3} / \mathrm{min}$ & & For breathing aỉr \\
\hline Utility air & $2 m^{3} / \pi i n$ & & One air tool operating \\
\hline Instrument air & $1 m^{3} / m^{*} n$ & & \\
\hline Utility water & 400 e/min & & Cask washdown \\
\hline Drinking water & $200 \mathrm{l} / \mathrm{min}$ & & $\begin{array}{l}\text { One eyewash/safety } \\
\text { shower operating }\end{array}$ \\
\hline Electricity & $100 \mathrm{kH}$ & & \\
\hline Ventilation & $750 \mathrm{~m}^{3} / \mathrm{min}$ & & \\
\hline Canísters & $2 \mathrm{ft}$ dig $\times \mathrm{B} f \mathrm{ft}$ long & 300 & \\
\hline He sources & & 325 & \\
\hline
\end{tabular}


Material Handling. The steps and the equipment required to bring the process materials into the facjlity and put them into canisters are considered to be the same as those required to introduce the process ind terial to the furnace in the reference process. The equipment required to seal, leak test, decontaminate, and transport the canisters will be about the same as that for the reference proces5. However, compaction does not require equipment to cool the canisters or to remove and recycle slag and starting stubs. Mechanisins to handle the canisters and to compact the process metals are much more involved than those required in the reference process to withdraw an ingot.

Consolidation Hode. Metal components are iripacted and pressed by a metal ram moved by a hydrautic cylinder. The only heat induced into the compacted metal in this mode is that generated due to friction and mechanical forces. Mechanisms for feeding the process material are external ta the consolidation station. The only atmospheric control required is to linit the spread of contamination.

Maintenance Considerations and Equipment Reliability. Other than the compactor instead of a furnace, the maintenance consiterations will be about the same for this process as for the reference process. The compactor involves many mechanical functions that are performed in the normal atmosphere and temperatures. High pressures are required; this, more maintenance will probably be required on a compactor than on a furnace although the reliability of the process may be comparable.

Controls and operations. The controls for and the operation of the compactor will be less complicated than those for the reference furnace.

Adaptabllity to Remate Operations. Conceptual designs have heen completed on at least two compactor concepts. With an adequate development; design, and testing progran, a compactor concept could be finalized that wowld be operable and maintatinable in a reikote nuclear hot cell.

Number of Process Steps. From the time a batch of metal is ready to be dumped into a canister until the canister is full of compacted metal has been estimated to require 32 batch-type operations. A total of 30 operations are 
required to complete the processing of one canister that contains $m 1.5$ times the metal of an ingot from the reference process or only $-40 \%$ of the materlal cast into a 2-ft dianeter by $10-f t$ long canister.

Feasibility for Production. One compactor and its supporting systems are deemed more than adequate and feasible for the intended operation.

Feed Limitations. Feed material sizes will be limited by canister size and compactability. Thus, feed limitations will be at least as restrictive as those of the reference process.

State and Type of Development

Process and/or Equipment. Concepts and designs of compactors for this application have been developed (AGNS 197B; Anderson et al. 1979).

Type and Scale of Developient. Developments that will be required before actual hot-cell operation of a cold compaction system include:

- develop the comactor concept, its controls, and monitoring systems

- demonstrate functional operation of large-scale compactor

- demonstrate remote operation and refiability of production-size compactor

- identify means to maintain compactor and components remotely

- demonstrate remote handling of canisters.

Development Time Required. Research, design, and testing could be performed in a period of 36 months.

Safety

The major safety concerns are fures from the zircaloy fines that occur as new nonoxidized surfaces are exposed during compaction) and the processing of radioactive material. Relatively high pressures and forces are involved in a few of the process steps. As with the reference process, all radioactive materials will be processed in shielded hot cells and devices designed for that purpose; therefore, the amount of excess radiation exposure will be a function of equipment maintenance and replacement or process accidents. 
Proces5 Reguirements

Secondary Wastes and Off Gases. Less secondary waste will be produced by this process than by the reference process due to the lack of slag. Due to lower temperatures $\left(60^{\circ} \mathrm{C}\right.$ versus $\left.600^{\circ} \mathrm{C}\right)$, fewer particulates, and less radioacm tivity, the off-gas system required for the compaction process is not as involved as that for any of the melting processes.

Production Capacity. One compactor can handle the projected throughput and has the capability of processing significant throughput increases.

Process Additions and Auxiliary Materials/utilities. Basically no process additives are required, and the utilities (power and water) that are required are considerably less than those of any of the metting processes.

Process Versatiljty and Control. No high temperatures, vacuums, or inert atmospheres are required in the compaction process although it does require high pressures (3000 psil). The amount of nonmetallic feed is not limited, and ingot integrity is not a concern. Container integrity after comaction is a definte quality control checkpoint.

Manpower. Aithough the use of this process will result in a graatar number of canisters being produced than all of the melting processes except the reference process, they can be produced in fewer days.

Facility Requi rements

The facility required for this process will be larger than that identified for the reference process.

\section{REFERENCES}

Allied-General Nuclear Services. 1978. Studies and Research Concerning BNF?: Storage and Handling of Wastes from Uranium Fuel Brocessing Alternatives. AGMS-1040-3.3-34, Barnwel], South Carolina.

Anderson, K. J., et al* 1979. Studies and Research Concerning BNFP: Engineering Evaluations of Wastes Handling and Storage facilities. AGMS35900-4.2-26, A17led-General Nuclear Services, Barnwelt, South Carolina, 
IABLE F.4. Cold Compaction System Evaluation maluator A

Complexity of Process

Material Handling

Consolidation Mode

Maintenance Considerations and Equipment Reliability

Controls and Operation

Adaptability to Remote Operation

Number of Process 5teps

Feasibility for Production

Feed Limitations

State and Type of Development

Process

Equipment

Type of Development

Scale of hevelopment

Development Time Required (from

initiation of program)

Safety

Stability and Atmosphere of Process Steps

Pyrophoricity, Exothermic, and Explosion Considerations

Personnel Radiation Exposure

Pracess Requirements

Secondary Wastes and Off Gases

Production Capacity

Process Additives and Auxiliary Materials

Process Versatillty and Control

Qualitiy Assurance

Utilities (atr, power, water, etc.)

Manpower

Facility Requirements

Noncontact Facilities (remote)

Contact Faciltties (hands-on)

Estimated Capital Cost

Total
Factor Weighting Rating Assigned $5 u b$

5

5

12

8

5

5

5

Total

60

\begin{tabular}{c}
\hline Sub \\
\hline \\
25 \\
30 \\
48 \\
72 \\
75 \\
15 \\
25 \\
25
\end{tabular}

40

5
10

10

10

5

40

50

\section{0} 5 
TABLE F.5* Cold Compaction System Evaluation - Evaluator B

Complexity of Process

Materíal Handing

Consolidation Mode

Maintenance Considerations and Equipment Reliability

Controls and Operation

Adaptablity to Remote Operation

Number of Process Steps

Feasibility for Production

Feed Linitations

State and Type of Development

Process

Equipilent

Type of Development.

Scale of Development

Developnent Tine Required (from

intiation of program)

Safety

Stability and Atmosphere of Process Steps

Pyrophoricity, Exothermic, and Explosion Considerations

Personne? Radiation Exposure

Process Reguipements

Secondary Wastes and off Gases

Production Capacity

Process Addituves and Auxiliary Materials

Process Versatility and Contro?

Quality Assurance

Utilities (air, power, water, etc.)

Manpower

Facility Requirements

Noncontact Facilities (remote)

Contact Facilities (hands-on)

Estimated Capital cost

Total
Factor Weighting

Sub Total

60

Rating Assigned

Sub

Total

357

5

5

12

40

40

72

40

75

25

40

25

40

260

40

60

70

50

40

40

340

10

20

100

160

10

80

30

245

50

40

50

25

15

15

50

30

130

10

10

50

50

30 
TABLE F.6. Cold Gompaction System Evaluation - Evaluator C

Complexity of Process

Material handling

Consolidation Mode

Maintenance Considerations and Equiprent

Reliability

Controls and Operation

Adaptability to Remote Operation

Number of Process Steps

Feasibility far Production

Feed Limitations

State and Type of Development

Process

Equiprnent

Type of Development

Scale of Developinent

Development Time Required (from

intitiation of program?

Safety

Stablility and Atmosphere of Process Steps

Pyrophoricity, Exothermic, and Explosion Consucerations

Personnel Radigtion Exposure

Process Requirements

Secondary Wastes and off Gases

Production Capacity

Process Additives and Auxiliary Materials

Process Versatility and control

Quality Assurance

Utillties (air, power, water, etc.)

Manpower

Facillty Rezuirements

Noncontact Facilities (remote)

Contact Facilities (hands-on)

Estimated Capital cost
Factor Weighting

Sub lotal

60

Rating Assigned

Sub

Total

344

5

5

12

25

60

8

64

15

5

5

5

40

220

20

5

10

10

10

5

40

250

10

20

10

100

100

50

30

250

50

40

50

40

15

15

50

30

190

10

80

100

10

10

Total 
TABLE F.7. Cold Compaction System Evaluation - Evaluator D

Complexity of Process

$\frac{\text { Factor Heighting }}{\frac{\text { Sub }}{60}} \frac{\text { Rating Assigned }}{\frac{\text { Total }}{266}}$

Material Handling

$5 \quad 10$

Consolidation Mode

5

Maintenance Considerations and Equipment 12

25

Reliability

Controls and Operation

Adaptability to Rerote Operation

Number of Process Steps

Feasibility for Production

Feed Linitations

$\begin{array}{rr}8 & 56 \\ 15 & 45 \\ 5 & 15 \\ 5 & 30 \\ 5 & 25\end{array}$

State and Type of Development

40

220

Process

5

Equipalent

10

Type of Developinent

10

Scale of Developrient

Developmant Time Required (from

intitiation of progran)

Sofety

40

220

Stability and Atmosphere of Process Steps

10

Pyrophoricity, Exothermic, and Explosion

20

70

Considerations

Personnel Radiation Exposure

10

50

Process Requirements

30

213

Secondary Wastes and Dff Gases

Production Capacity

Process Additives and Auxiliary Materials

Process Versatility and Control

Quality Assurance

Utilities (air, power, water, etc.)

Manpower

4

5

Facility Requirements

Noncontact facilities (remote)

10

40

10

80

Estimated Capital cost

10

50

Tatal

1089 
APPENDIX G

EVALUATION CHECKLIST 


\section{APPENDIX G}

\section{EVALUATION CHECXLIST}

Items similar to those identified in this appendix were used as a checklist to evaluate the consoludation methods or processes. The process information in Appendices A through $F$ was used to establish basic characteristics. This information was integrated with the bases and assumptions identified in the text and supplemented by other sources and the knowledge of the authors and consultants to identify to the extent passibie the relative requirements of each method or process.

\section{COMPLEXITY OF PROCESS}

- material handling aspects

- How are process materials introduced to the system?

- How are process materials removed from the system?

- How are in-process transfers of radloactive materials made?

- What is the magnitude of material recycling?

- method or process used for radiactive material consolidation

- equipment reliability and matntainability

- number and type of mechanical components

- number and type of electrical components

- special features required for remote removal or maintenance

- special features requíred for decontamination

- size of equipment and components

- time required for equipment/component replacement or maintenance

- frequency of routine matitenance 
- potential for trapment/absorption of process material

- ramifications of controls and operations

- critical control parameters

- magnitude and complexity of in-cel1 controls

- utilization of closed cịcutat television

- process reactions/canditlons at each process step (time, ternperature, pressure, etc.)

- methods required to achieve remote control

- in-pracess sampling needs and requirements

- adaptation to remote process

- complexity of equipment/process

- remote cell(s) arrangements and limitations

- visual access required or attainable

- number and magnitude of process step or operation: continuous, batch, or combination

- remote production feasibility

- magnitude of scalewp required

- one or more parallel process lines

- feed linitations Inaximur size, configuration, range of sizes, ard configuration mixes).

STATE ANO TYPE OF DEVELOPMENT OF EQUIPMENT/PROCESS REQUIRED

- use in remote radioactive applications

- adaptability of equipment to remote operation

- type and magnitude of development efforts required 
- type and magnitude of development efforts that may improve anticipated equipment performance

- time and cost requirements for developmental efforts.

\section{OVERALL SAFETY CONSIDERATIONS PERTINENT TO THE PROCESS AND EQUIPMENT}

- routine releases of radioactive materials

- potential for elevated releases during process upsets

- potential for catastrophic releases due to process ar equipment malfunction

- effects of process conditions for example, temperature and pressure) on confinement of radioactive materials

- hazardous materials requared in process other than the process feed)

- explosive or potentially explosive materials required in process

- spread of radioactive materials.

\section{OVERALL PRDCESS REQUIAEMENTS}

- reagents, process additions, supplies

- services and utilities

- process latitudes and effects of feed variations

- process upsets and effects on product quality ar recycle

- number of and qualifications for personnel

- number af shifts per day

- startup and shutdowr ramifications.

OVERALL FACILITY REQUIREMENTS FOR RADIOACTIVE PROCESS OPERATIONS AND SUPPORTING EQUIPMENT AND SERVICES

- total shielded cell space required

- supporting facilities required

- complexity of mechanical operations required 
- equipment redundancy required to meet scheduled throughputs

- use of cranes, master-slave manipulators, electromechanical manipulators, robotics, etc. 


\section{APPENDIX H}

PROCESS RATING GUZDE 
A list of descriptive statements was used to identify levels of merit for each criterion. Each criterion was assigned a value fron 1 to 10; a high numerical value indicates high merit attributed to the process in respect to that criterion. For example, for the attribute of process complexity, the least complex process was accorded the highest merit. All ratings are subjective,

\section{RATING OF THE PROCESS}

The rating of each process is the summation of the products of criterion weight and ranking for a 11 criteria. Appropriate comments are entered where necessary.

DESCRIPTIVE STATEMENTS

Complexity of Process

Material Handling: Material handling includes charging metals to the process, removing ingots and/or canisters, and recycling process material. The ratings consisted of;

10 - requires limited handing of charge materials and product

5 - requices moderate handing of charge materials and product

1 - requires substantial handling of charge materials and product.

Consolldation Made. The consolidation patings consisted of:

10 - process is simple and equipnent is few in number

5 - process is simple but equipment is complicated

1 - both process and equipment are complicated.

Ma intenance Considerations and Equigment Reliability. The ratings for this criterion consisted of: 
10 - equipment is relatively simple or few in number

Q - nominal maintenance frequency and duration; components can be serviced or replaced easily and nominal maintenance is required

5 - equipment includes complex mechanical/electrical components in cell with limited or restricted access

1 - equipment must be decontaminated and maintat ned in place. Cantrols and Operation. The ratings for this criterion consisted of: 10 - minimal controls on material flow quanticies and process conditions; process can accommodate wide variation in operating parameters

- straightforward controls on process conditions; process can accommodate variations in operating parameters

6. - numerous controls necessary; limited variation in operating parameters

4 - complex control required; close control of process is essential

I - complex controls required; fallure of control system can lead to serious upset condition or safety problem.

Adaptability of Equipment to Remote Opepation. The following ratings were assigned to this criterion:

10 - equipment has been used in radioactive production operations

8 - equipment has been used in radioactive pillot-plant operations and performed satisfactorily

6 - equipment has been designed for remote operation but only tested in simulated remote operation

4 - equipment remotely operable and relatively uncomplicated

2 - equipment adaptable to remote operation

1 - questionable that equipment could be designed for remote operation or maintenance. 
Number of Process Steps. The ratings for this category consisted of:

10 - small number of batch or continuous operations performed in automatic sequence

5 - nominal number of simple operations performed in semiautomat to process

1 - Targe number of complex operations performed on a step-to-step integrated bases.

Feasiblity for Production. This criterion is basically an assessment of the probabllity of success of a development program of reasonable and prudent scale. The ratings consisted of:

10 - process and equipment are relatively simple; adaptation to largemscale use is clearly possible

8 - process and equipment are relatively simple but include one or mare steps that may be questionable for long-term continuous operation

6 - process and equipment are moderately complex and include one or more steps that may be difficult for long-term continuous operation

4 - process includes one or more steps about which there is some doubt that scale-up to production operation will be practicable

1 - available information indicates that the process may not be feasible for production use.

Feed Limits. The following ratings were assigned to this category:

10 - process and equipment can handie a wide range of feed material 5 †̇es

5 - definite limits exist on the size of process material feads

1 - size of process feed material is extrenely limited.

State of Development

Process. This criterion was ranked as follows: 
10 - demonstrated technology; routinely used in production-scale radiochemical operations

8 - demonstrated technology; production-scale operating experience with materials other than those involved in proposed application or extensive hot pillotmplant work on same types of materials

6 - extensive coid pilot scale work with simulated products

4 - small pilot-scale work on individual process operations (nonradioactive)

1 - limited or no laboratory work.

Equipment. The ratings for this criterion included:

10 - equipment has been demonstrated in remote production operation

8 - equipment has been demonstrated in simulated nonradioactive remote operation

6 - equipment of standard commercial (nonradioactive use) design has been used in similar process: satisfactory perfarmance

4 - equipment of standard comerctal design must be modified to satisfy special process requirements

2 - no commercial equipment is available that will perform required function

1 - no experimental equipment is available that would serve the required purpase.

Type of Development. The development scale is sequential from I to 10 ; that is, a process rated at 4 implies that development states 1,2 , and 3 have been completed and 4 through 10 remain to be accomplished. In some cases. (for example, where the pracess is reasonably simple, the equipment is uncamplicated, or there are extensive data on nonnuclear applications of the process and/or equipment), one or more of the identified development stages may be skipped. 
The following ratings were assigned to this criterion:

10 - process requires only cold shakedown of full-scale facility; i.e., available data would pentit design of production-scale hot facility

9 - limited hot pllot-plant work required to confirm process latitudes

7 - extensive hot pilot-plant work required to confirm process and equipment design data

6 - radioactive equipment development required

5 - phot-scale process development to establish equipment and process scale-up factors

4 - nonradioactive equipment development

3 - process and equipment materials development

2 - small-scale not cell process development

1 - nonradioactive Taboratory process development.

Scale of Development. The following ratings were assigned to this criterion:

10 - equipment has been developed; factitities available for radioactive development work

8 - minimal radioactive facilities required to gather necessary design data

6 - extensive hot pilot-plant facilities required; minimum complexity

5 - extensive hot pilot-plant facilities required; complex process; equipment design data avallable but scale-up information needed

3 - equipment and process data require remate operation verification 
2 - considerable complex equipment to be designed and proven on nonradioactive basis

1 - no equipment design data avaliable.

Development Time Required. The time required from the initiation of program was ranked as follows:

$10-0$ to 1 yr

$9-1$ to 2 yr

B -2 to $3 y r$

$5-4$ to 5 yr

1 - more than 5 yr.

Safety Considerations

Stabflity and Atmosphere of Process Steps. The ratings for this criterion consisted of:

10 - process operates at temperatures of $1000^{\circ} \mathrm{C}$ or less and moderate pressures

9 - process operates at 1000 to $1900^{\circ} \mathrm{C}$ and subatmospheric pressures

7 - process operates at subatmospherte pressures and in excess of $1900^{\circ} \mathrm{C}$

5 - process operates in excess of $1900^{\circ} \mathrm{C}$ with gas pressures at atmospheric or above

1 - process includes high pressure and high temperature (in excess of $\left.1900^{\circ} \mathrm{C}\right)$.

Pyrophoricity, Explosive, and Exothermic Considerations. The following ratings were assigned:

10 - no steps provide potential for pyropharic, exothermic, chenical process upsets, spilis, or dispersions

5 - moderate potential exists for process material dispersion

1 * materials with high toxicity or with explosive potential required. 
Personnel Radiation Exposure. Exposures include routine, accident, and maintenance operations and were ranked as follows:

10. low potential for component faflure and replacement

5 - moderate potential for major component fallure due to error or other malfunctions

1 - life of major equipment components is potentially short.

Process Requirements

Secondary Wastes and of G Gases.

10 - wastes and of gases are less than those of reference process

5 - wastes and off gases are essentially the same as those of the reference process

1 - wastes and off gases are significantly greater than reference process.

Production Capacity.

10 - one reasonably sized production line capable of processing the required throughput with excess capacity

5 - long process pertod required for unit throughput or no excess capacity

1 - mitiple or large-size equipment required to process throughput.

Process Additives and Autillary Materials.

10 - requires minimum additives of moderate cost

7 - requires large quantities at maderate cost

4 - requires limited quantities at high cost

1 - requires large quantities at high cost.

Process Versatily and Control.

10 - process capable of accepting substantial variations in feed composition and process conditions 
8 - process moderately susceptible to effects of variations in feed composition

6 - process requires moderately tight control of process conditions

4 - process requires tailoring of reactants/additives for each batch of feed

3 - process requires very tight control of process conditions

1 - process may not be capable of being controlled so as to produce the desired product.

Quality Assurance.

10 - simple process; minimum quality control problems

5 - product quality controlled through control of input materials quantity and composition

1 - product quality can be determined only by evaluation of finished product.

Utijities.

10 - process additives, supplies, utilities, and services are less than those of the reference process

5 - requirements about the same as for the reference process

1 - requirements considerably more than for the reference process*

Manpower.

10 - requires considerably jess manpower/yr than reference process

5 - requires essentially the same manpower/yr than reference process

1 - requires significantly more manpower/yr than reference process.

\section{Facllity Requỉ rements}

Facility requirements include structures (eveluated as volume), equipment (evaluated as number of items and complexity of installation); special maintenance factlities, and process auxlliaries fevaluated as number of items and complexity of installation). 


\section{Radioactive Facilities.}

10 - facility requirements are less than those of the reference process

8 - shielded cell requirements are similar to the reference process; no complex installations

4 - shielded cell requirements greater than for reference process; some complex installations required

1 - significantly greater shieided space requirements; many complex equipment installations required.

Nonradioattive Facilities.

10 - facllity requil rements not materially different from the reference process

5 - facility requirements signficantly greater than for reference process but of a commonily used industrial character

1 - extensiva facilities for material storage and preparation required outside of process cells; high temperature or possibly toxic materials must be provided to process.

\section{Estimated Capital Costs}

10 - costs are considerably less than those of the reference process

5 - costs are about the same as those of the reference process

l - costs are considerably higher than those of the reference process. 
* 


\section{DISTRIBUTION}

Ho. of

Copies

DFFSITE

27 OOE Technical Information Center

\section{$R$. $E$, Cunningham \\ Office of Nuclear Safety}

Materials and Safeguards

U.5. Nuclear Regulatory Commission

7915 Eastern Avenue

Silver Springs, M[3 20910

2 Division of Waste Management

U.5. Nuclear Regulatory Commisston Washington, OC 20555

ATTN: J. B. Martín

R. O. Smith

\section{W. E. Mott}

DOE Diviston of Envìronmental

Control Technology

Washington, DC 20545

10 DOE Nuclear Waste Management

and Fue Cycle Programs

NE 30, GTN

Hashington, OC 20545

ATTN: W. W. Ballard

F. E. Coffman

ง. A. Coleman

H. Feinroth

D. P. Gormley

M. J. Lawrence

W. H. Mc Vey

R. H. Ramsey

D. W. Shelar

J. A. Turl
No. of

Coples

6 DDE Dffice of Defense Waste and Byproducts

DP-12, GTN

Washington, $\mathrm{OC} 20545$

ATTN: A. A. Camacho

J. E. Oieckhoner

J. J. Jicha

G. K. Qertel

A. L. Taboas

V. G. Trice

4 DOE Office of Civilian Waste Products Washington, OC 20545

ATTN: $C, R$, Cooley

W. Eister

C. Klingsberg

W. Morgan

W. F. Hol comb

National Institutes of Health

B) dg. 21

Radiation Safety Branch

Bethesia, MO 20205

5. A* Mann

DOE Chicago Dperations and Region office

Argonne, IL 60439

J. 0. Neff

DOE Columbus Program Office 505 King Avonue

Columbus, OH 43201

J. P. Hamric

DOE Idaho Operations Office

5520 2nd Street

ldaho Falls, In 63401 
H. of

Copies

Office of the Assistant Manager for Energy Research and Cevel opment

OOE Oak Ridge Operations Office

P.D. Box E

Dak Ridge, TN 37830

2 Oak Ridge National Laboratory

P. 0. Box $x$

Oak Ridge, Tr 37030

ATTN: J. 0, Blomeke

$$
\text { A. L. Lotts }
$$

2 OOE Albuquerque Operations office P. 0. Box 5400

Al buquer que, NM 87185

ATTN: R. Y. Lowrey

M. H* Hadden

2 E. 1, du Pont de Remours and Co.

Savannah River Laboratory

Aiken, SC 29801

ATTN: E. E. Al benesius

J. L. Gandall

J. J. Cohen

Science Applications, Inc.

1011 South Rita Road

Suite 104

Pleasanton, CA 94566

M. P* Schl ienger

Retech, Inc,

P. 0. Box 357

Ukah, CA 95482

2 Iransuranic Waste Systens office

Rockwell Internationa!

Rocky Flats Flant, Bldg* 001

P.D. Box 464

Golden, $C 080401$

ATTN: K. $V$, Gilbert

P. G. Hagan

Law ence Livermore Laboratory

Reference Library

P.0. Box g08

Livermore, CA 94550
No. of

Copies

G. B. Levin

EG\&G Idaho, Inc *

P.O. Box 1625

Idaho Falls, ID 83401

Los Al amos katjonal Laboratory

Reference Library

P. D. Box 1663

Los Al amos, NiM 87544

Sayannah River Laboratory

Reference Library

Ajken, SC 29001

2 OOE Sayannah River Operations

P.O. Eox A

Aliken, SC 29801

ATTN: $E . \quad S$. Gol dberg

T. B, Hindman

S. G. Harbinson

DOE San Francisco Operations

1333 Broadway

Cakland, CA 94612

2 Argonne Nitional Laboratory

9700 South Cass Avenue

Argonne, IL 60439

ATTN: 3. H. Kittel

H. J. Steindler

J. [wymer

West Valley Nuclear Serviees

P.0. Box 191

West Valley, NY 14131

5 Battelle Memarial Institute

Office of Nuclear Waste Isolation

$505 \mathrm{King}$ Avenue

Col umbus, $\mathrm{OH} 43201$

ATti: S. Bashom

A* Bauer

W. Corbiener

3. Kircher

B. Rawles 
No. of Copies

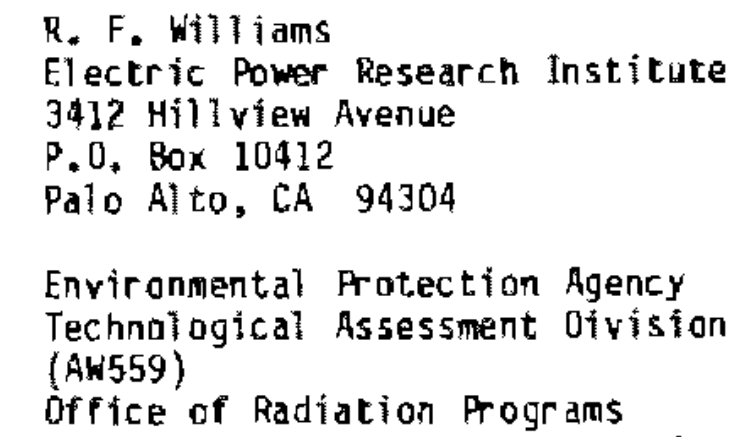

$5 \quad 00 E$ Richland Gerations of fice

E. A. Bracken

H. E. Ransam
No * of

Copies

J. J. Schrejber

M. H. Shupe

$F$ * R. Standerfer

Westinghouse Hanford Company

A. G. Blasewitz

4 Rackwell Hanford Operations

G. A. Beitel

J. L. Deichman

K. A. Gesper

M. J. Smith

\section{Pacific Northwest Laboratory}

R. P. All en

W. J. Bjorkl and

W. F. Bonner

D. I. Bradley

J. B. Brown

H. B. Burkhol der

J. R. Carrell

T. D. Chikalla

E. L. Courtright

R. L. Dillan

S. K. Edter

J. H. Jarrett

R. 5. Kemper

D. E. Knowiton

M. R. Kreiter

D. E* Larson

J. M. Latkovich

R. C* Lifikala

d. L. MEElroy

J. E. Mendel

J. E. Minor

D. R. Montgomery

I. C. Nel son

R. G. San san

R. E. Nightingale

J. F. Nesbitt (5)

A. $M$. Platt

J. V. Robinson

W. A. Ross (5)

5. C. Sl ate

S. L. Stein 
No. of

Contes

C. L. Timmerman

R. L. Treat

R. P. Turcotte

C. M. Unruh
No. of

Copies

H. H. Van Tuyl

E. J. Wheelwright

Technical Information (5)

Publishing Coordination (2) 